EDNEI ASSUNÇÃO ANTUNES COELHO

EFEITOS DA RADIAÇÃO GAMA E FEIXE DE ELÉTRONS SOBRE AMOSTRAS DE CASTANHAS-DO-BRASIL INOCULADAS

ARTIFICIALMENTE COM Aspergillus flavus

Dissertação apresentada ao Programa de Pós-Graduação em Microbiologia do Instituto de Ciências Biomédicas da Universidade de São Paulo, para obtenção do Título de Mestre em Ciências. 
EDNEI ASSUNÇÃO ANTUNES COELHO

\section{EFEITOS DA RADIAÇÃO GAMA E FEIXE DE ELÉTRONS SOBRE AMOSTRAS DE CASTANHAS-DO-BRASIL INOCULADAS ARTIFICIALMENTE COM Aspergillus flavus}

Dissertação apresentada ao Programa de Pós-Graduação em Microbiologia do Instituto de Ciências Biomédicas da Universidade de São Paulo, para obtenção do Título de Mestre em Ciências.

Área de concentração: Microbiologia

Orientação: Prof. Dr. Benedito Corrêa

Versão original 
DADOS DE CATALOGAÇÃO NA PUBLICAÇÃO (CIP)

Serviço de Biblioteca e Informação Biomédica do

Instituto de Ciências Biomédicas da Universidade de São Paulo

reprodução não autorizada pelo autor

Coelho, Ednei Assunção Antunes.

Efeitos da radiação gama e feixe de elétrons sobre amostras de castanhas-do-Brasil inoculadas artificialmente com Aspergillus flavus / Ednei Assunção Antunes Coelho. -- São Paulo, 2012.

Orientador: Prof. Dr. Benedito Corrêa.

Dissertação (Mestrado) - Universidade de São Paulo. Instituto de Ciências Biomédicas. Departamento de Microbiologia. Área de concentração: Microbiologia. Linha de pesquisa: Micotoxinas.

Versão do título para o inglês: Effects of gamma radiation and electron beam on samples of the Brazil nuts artificially inoculated with Aspergillus flavus.

1. Castanha-do-Brasil 2. Aspegillus flavus 3. Aflatoxinas 4. Radiação gama 5. Feixe de elétrons I. Corrêa, Prof. Dr. Benedito II.

Universidade de São Paulo. Instituto de Ciências Biomédicas. Programa de Pós-Graduação em Microbiologia III. Título. 
Ednei Assunção Antunes Coelho.

Título da Dissertação: Efeitos da radiação gama e feixe de elétrons sobre amostras de castanhas-do-Brasil inoculadas artificialmente com Aspergillus flavus.

Orientador(a): $\quad$ Prof. Dr. Benedito Corrêa.

A Comissão Julgadora dos trabalhos de Defesa da Dissertação de Mestrado, em sessão pública realizada a considerou
( ) Aprovado(a)
( ) Reprovado(a)

Examinador(a): Assinatura:

Nome:

Instituição:

Examinador(a): Assinatura:

Nome:

Instituição:

Presidente: Assinatura:

Nome:

Instituição: 
Cidade Universitaria "Armando de Salles Oliveira"

Av. Prof. Lineu Prestes, 2415 - CEP. 05508-000 Sáo Paulo, SP - Brasil

Telefone :(55) (11) 3091-7733 - telefax : (55) (11) 3091-8405

e-mail: cop

\section{CERTIFICADO DE ISENÇÃO}

Certificamos que o Protocolo (CIP-IC:B \"394/10 referente ao projeto intitulado: "Efeitos da radiação gama e feixe de elétrons na contaminação fúngica e por aflatoxinas em castanba-do-brasil" sob a responsabilidade de Ednei Assunção Antunes Coelho, foi analisado na

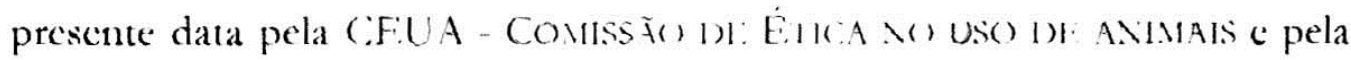

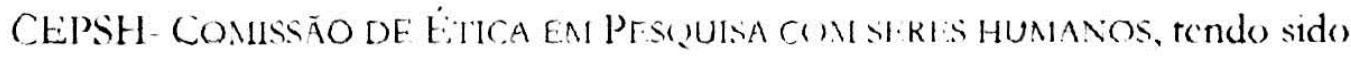
deliberado que o referides projeco nàs envolve manipulaçàs animal ou humana que justifique uma aprovaçà quanto aes principios éticos exigidos por ambas as comisisers.

Sacs Paulo, 21 de junho de 2010.
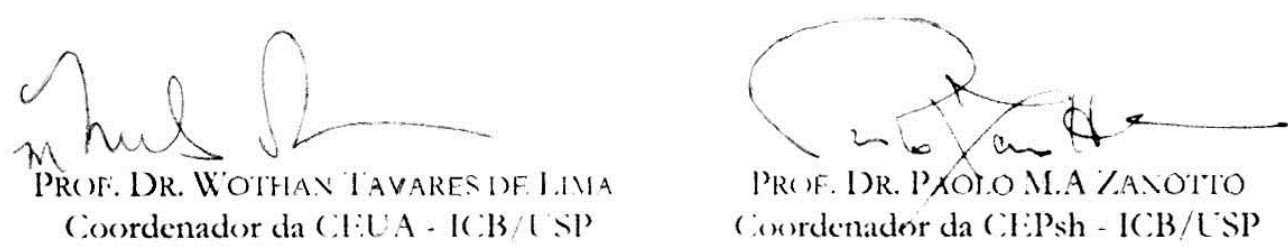
Aos meus pais, que são exemplos para a minha vida, "é na educação dos filhos que se revelam as virtudes dos pais", familiares e amigos pela dedicação, incentivo e apoio constante para a minha formação.

Obrigado! 


\section{AGRADECIMENTOS}

Ao Prof. Dr. Benedito Corrêa, por sua confiança, amizade, apoio e principalmente por acreditar no meu potencial para a elaboração de um projeto de pesquisa tão importante.

À Dra. Arianne Costa Baquião, pela amizade, e pelos valiosos ensinamentos nos períodos de estágios dentro do laboratório.

À Tatiana Alves dos Reis, pela amizade, compreensão, apoio técnico e principalmente por ser uma excelente pesquisadora e funcionária do Laboratório de Micotoxinas, obrigado pelos ensinamentos que foram cruciais para a elaboração de todos os meus experimentos e tese.

Aos meus amigos, Vinicius de Moraes, Mariana Sconza, Maitê Oliveira, Danielle Atayde, Ludmila Jalaim, Patrícia Zorzete, Tainah Drumond, Diego Rossi, Julian Esteban.

Aos companheiros do Laboratório de Micotoxinas, pela parceria durante o estágio e trabalho.

Ao Instituto de Pesquisas Energéticas e Nucleares - IPEN, pelo suporte na irradiação das amostras utilizadas nos experimentos. Principalmente aos funcionários Carlos e Beth pelo apoio e incentivo à pesquisa. À Prof. Dra. Susy Sabato e ao Wladimir.

Á ACECIL (Central de Esterilização, Comércio e Indústria Ltda), pela ajuda na esterilização das amostras e apoio à pesquisa.

A fundação de Amparo a Pesquisa do Estado de São Paulo (FAPESP) pelo apoio financeiro.

A Deus, por tudo. 
"Sinto-me confortável com o desconhecido, esse é o ponto da Ciência. Eu não preciso de uma resposta, eu não preciso de respostas para tudo. Eu quero ter respostas para encontrar."

Brian Cox 


\section{RESUMO}

COELHO, E. A. A. Efeitos da radiação gama e feixe de elétrons sobre amostras de castanhas-do-Brasil inoculadas artificialmente com Aspergillus flavus. 2012. $85 \mathrm{f}$. Dissertação (Mestrado em Microbiologia) - Instituto de Ciências Biomédicas, Universidade de São Paulo, São Paulo, 2012.

Com o elevado índice de contaminação por aflatoxinas, produzidas por fungos, em lotes de castanha-do-Brasil e o rigoroso controle dos países importadores em relação aos níveis de toxinas presentes nos alimentos, os países da União Européia decidiram em 2003 pela devolução de lotes destes produtos oriundos do Brasil. Apesar da perda econômica, representada pela contaminação por fungos toxigênicos em castanhas-doBrasil, um importante produto extrativista da região Norte do Brasil, estudos realizados ainda são incipientes quanto ao controle da contaminação por fungos aflatoxigênicos utilizando métodos como radiação gama (R.G) e, sobre tudo, feixe de elétrons (F.E). Esses fatos motivaram a presente pesquisa, que teve como objetivo avaliar os efeitos da radiação gama e da aplicação de feixe de elétrons em amostras de castanha-do-Brasil inoculadas artificialmente por Aspergillus flavus. Para atingir tal objetivo foram estudadas 50 amostras de castanha-do-brasil, previamente, inoculadas com suspensão de esporos de A. flavus e, posteriormente, incubadas a $30^{\circ} \mathrm{C} \mathrm{em}$ ambiente com umidade relativa controlada a $93 \%$. Após período de incubação de 15 dias, a atividade de água média das amostras foi de 0,80 e as amostras foram subdivididas em 5 grupos que receberam as seguintes doses de radiação: controle (0 kGy), 5 e 10 kGy F.E, 5 e 10 kGy R.G. A micobiota foi realizada através de diluição seriada, com semeadura em superfície utilizando ágar batata. Os resultados demonstraram que o tratamento com F.E utilizando a dose de $5 \mathrm{kGy}$ e $10 \mathrm{kGy}$ resultou na redução de crescimento de A. flavus em $74 \%(37 / 50)$ e $94 \%$ (47/50) das amostras. Quanto às amostras tratadas com R.G na dose de 5 kGy e 10 kGy não ocorreu crescimento fúngico em 92\% (46/50) e 100\% (50/50) das. A pesquisa de aflatoxinas mostrou que doses de F.E de 5 kGy e 10 k Gy reduziram os níveis de $\mathrm{AFB}_{1}$ em 53,32\% e 65,66\%, respectivamente. Por sua vez, a aplicação de raios gama nas doses de 5 e $10 \mathrm{kGy}$ reduziu os níveis das toxinas em $70,61 \%$ e $84,15 \%$ respectivamente. Esse resultado pode ser atribuído a maior penetrabilidade da radiação gama. Análise sensorial demonstrou maior aceitação dos julgadores pelas amostras irradiadas com F.E e R.G na dose de 10 kGy. Concluímos que, apesar de a análise sensorial ter demonstrado perda de algumas características organolépticas, ambos os processos de radiação foram eficazes na redução da contagem de A. flavus e de aflatoxinas.

Palavras-chave: Castanha-do-Brasil. Aspergillus flavus. Aflatoxinas. Radiação gama. Feixe de elétrons. 


\begin{abstract}
COELHO, E. A. A. Effects of gamma radiation and electron beam on samples of the Brazil nuts artificially inoculated with Aspergillus flavus. 2012. 85 p. Masters thesis (Microbiology) - Instituto de Ciências Biomédicas, Universidade de São Paulo, São Paulo, 2012.

The high level of contamination by aflatoxin produced by fungi in lots of Brazil nuts and the strict control by importing countries in relation to the levels of toxins in food, European Union countries decided in 2003 by the return of these lots products from Brazil. Despite the economic loss represented by contamination by toxigenic fungi in Brazil nuts, a major product of extractive Northern of Brazil, studies are still preliminary as the control of contamination aflatoxigenic fungal using methods such as gamma radiation (G.R) and mainly, electron beam (E.B). These facts motivated this research, which aimed to evaluate the effects of gamma radiation and application of electron beam in samples of Brazil nut artificially inoculated with Aspergillus flavus. This goal, we were studied 50 samples of the Brazil nut previously inoculated with spores of $A$. flavus and subsequently incubated at $30{ }^{\circ} \mathrm{C}$ in relative humidity controlled at $93 \%$. After incubation, period of 15 days, the average water activity of the samples was 0.80 , the samples were divided into 5 groups that received the following doses of radiation: control $(0 \mathrm{kGy}), 5$ and $10 \mathrm{kGy} 5$ E.B and G.R. The mycobiota was performed by serial dilution, plated on surface using potato dextrose agar. The results demonstrated that treatment with E.B using a dose of $5 \mathrm{kGy}$ and $10 \mathrm{kGy}$ resulted in reduced growth of A. flavus in 74\% (37/50) and 94\% (47/50) of samples. The samples treated with G.R at the dose of $5 \mathrm{kGy}$ and $10 \mathrm{kGy}$ no fungal growth occurred in 92\% (46/50) $100 \%$ (50/50) of. The study of aflatoxins showed that doses of E.B of $5 \mathrm{kGy}$ and $10 \mathrm{kGy}$ reduced levels of $\mathrm{AFB}_{1}$ at $53.32 \%$ and $65.66 \%$ respectively. The application of gamma rays at doses of 5 and $10 \mathrm{kGy}$ reduced levels of toxins in $70.61 \%$ and $84.15 \%$ respectively. This result may be attributed to higher penetrability of gamma radiation. Sensory analysis showed greater acceptance of the judges for the samples irradiated with E.B and G.R at the dose of $10 \mathrm{kGy}$. We concluded that although sensory analysis have demonstrated some loss of organoleptic characteristics, both processes of radiation were effective in reducing the count of A. flavus and aflatoxin contamination.
\end{abstract}

Keywords: Brazil nuts. Aspergillus flavus. Aflatoxins. Gamma radiation. Electron beam. 


\section{LISTA DE ILUSTRAÇÕES}

Tabela 1 - Composição centesimal e valor energético da castanha-do-Brasil comestível..........17

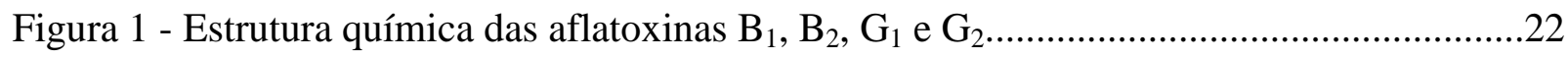

Figura 2 - Penetrabilidade da radiação ionizante, partículas $\alpha, \beta$ (Elétrons) e raios gama.........26

Figura 3 - Exemplo efeito direto da radiação no DNA.................................................................33

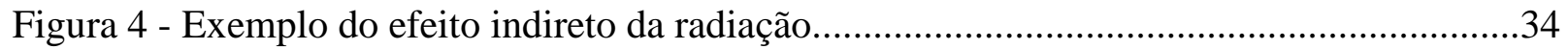

Quadro 1 - Comparação entre radiação gama e por feixe de elétrons.......................................30

Quadro 2 -Níveis de Aa das amostras de castanha-do-Brasil, antes e após incubação por 15 dias.

Quadro 3 - Número de UFC/g de A. flavus após período de incubação de 15 dias em amostras artificialmente inoculadas: controle e após os tratamentos por radiação ionizante.......50

Tabela 2- Distribuição da concentração de aflatoxinas por tratamento.

Quadro 4- Concentração de $\mathrm{AFB}_{1}(\mu \mathrm{g} / \mathrm{kg})$ em amostras antes da inoculação artificial, e após 15 dias de inoculadas (controle) e após os tratamentos por radiação ionizante. .55

Gráfico 1- Análise estatística das notas atribuídas pelos julgadores para a característica de odor de castanha-do-Brasil irradiada.

Gráfico 2 - Médias das notas atribuídas pelos julgadores para a característica de sabor de castanha-do-Brasil irradiada...... .58

Gráfico 3 - Médias das notas atribuídas pelos julgadores para a característica de textura de castanha-do-Brasil irradiada. .58

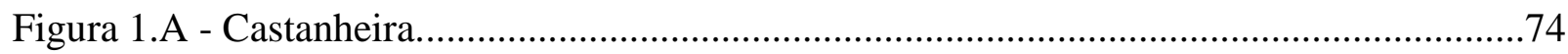

Figura 2.A - Castanha-do-Brasil com casca dentro do ouriço.................................................74

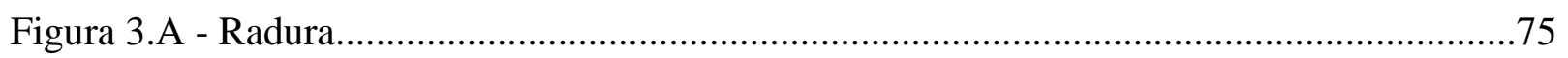

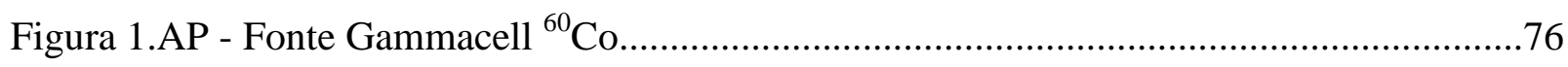

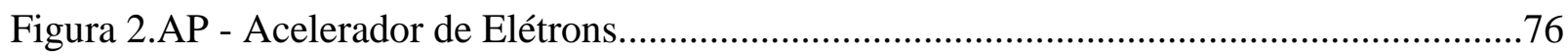

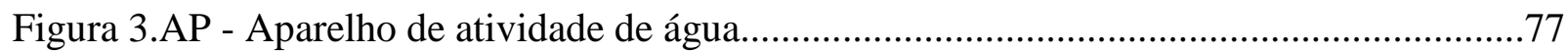

Figura 4.AP - Cromatógrafo líquido de alta eficiência..............................................................77

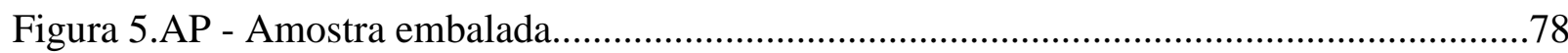

Figura 6.AP - Micobiota antes dos processos de radiação.......................................................78

Figura 7.AP - Micobiota após o processo de irradiação com 5 kGy por Feixe de Elétrons........79

Figura 8.AP - Micobiota após o processo de irradiação com 10 kGy por Feixe de Elétrons......79

Figura 9.AP - Micobiota após o processo de irradiação com 5 kGy por Radiação Gama............80 
Figura 10.AP - Micobiota após o processo de irradiação com 10 kGy por Radiação Gama......80

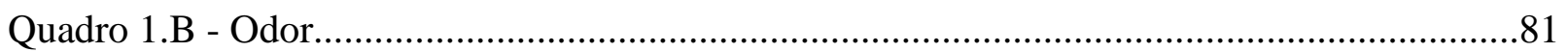

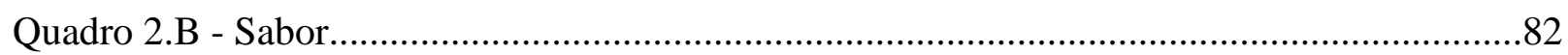

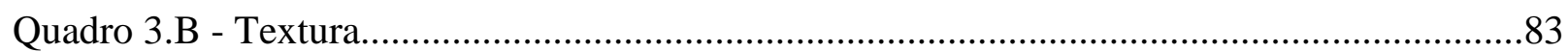




\section{SUMÁRIO}

1 INTRODUÇÃO E REVISÃO DA LITERATURA ....................................................14

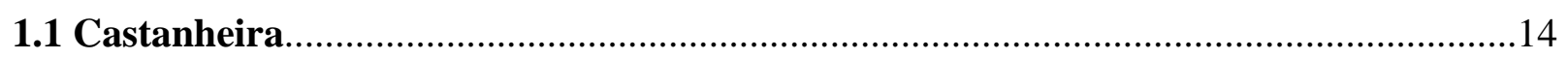

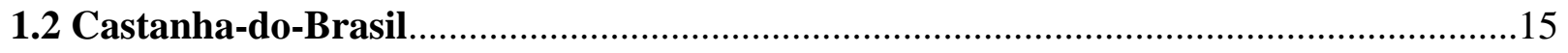

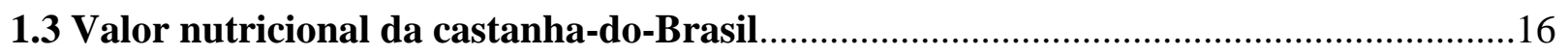

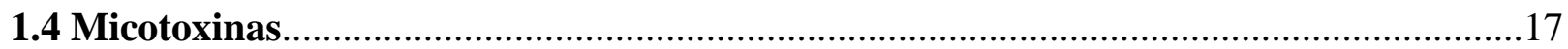

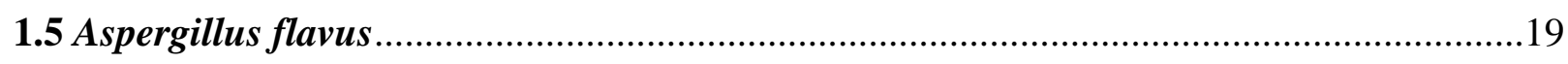

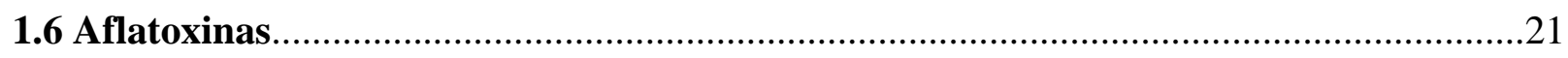

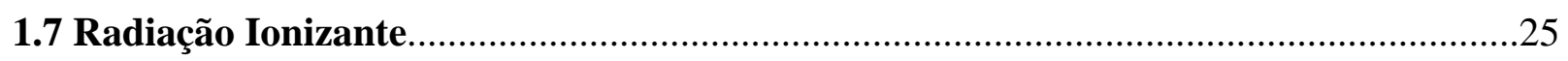

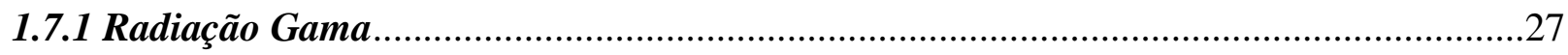

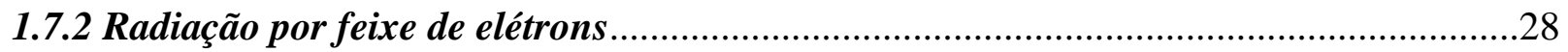

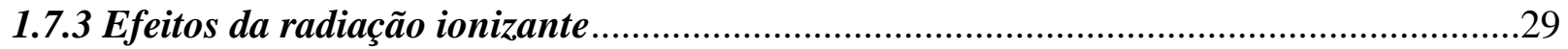

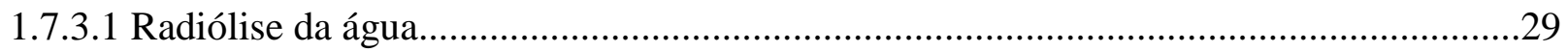

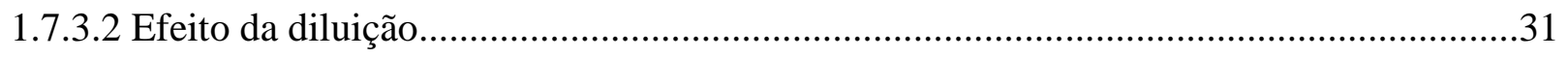

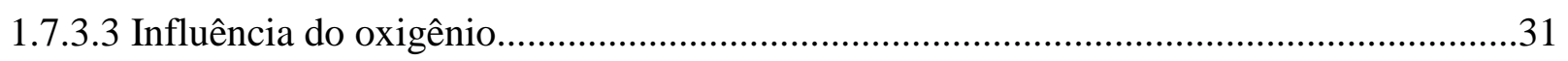

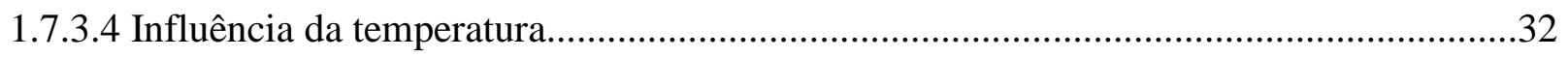

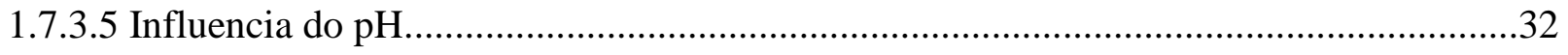

1.7.3.6 Efeito direto e efeito indireto da radiação ionizante.......................................................33

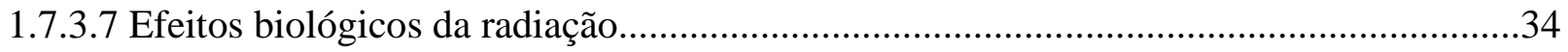

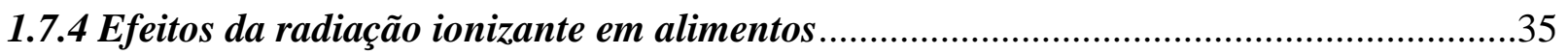

1.7.4.1 Legislação para irradiação de alimentos....................................................................37

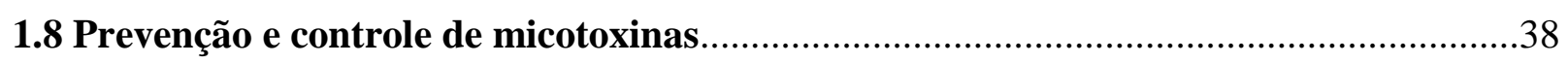

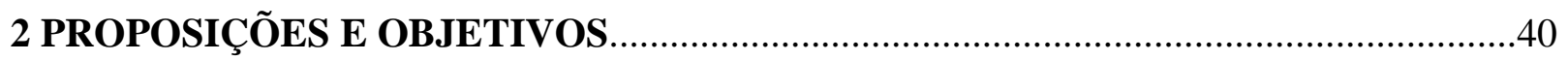

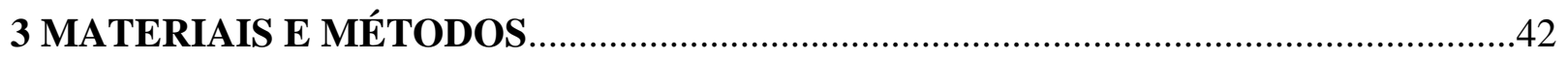

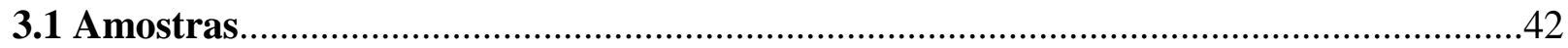

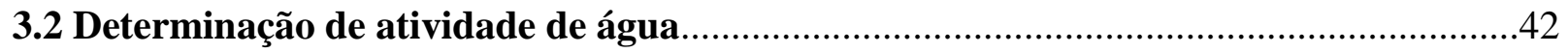

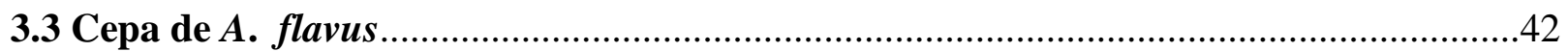

3.4 Condições de incubação das amostras inoculadas com A. flavus .................................43

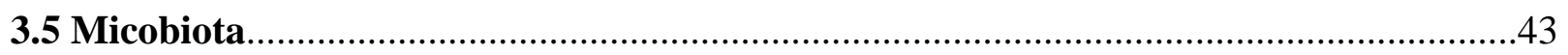

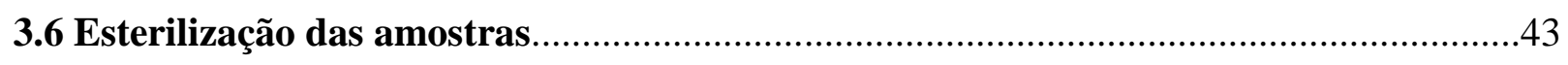

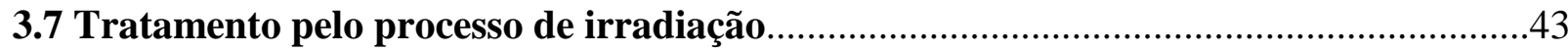




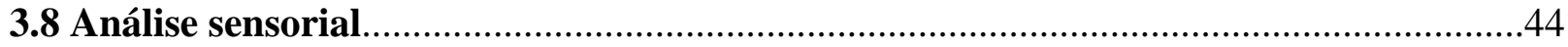

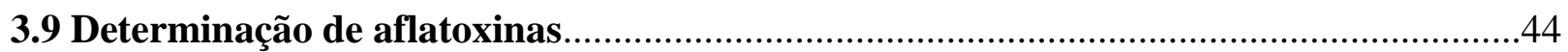

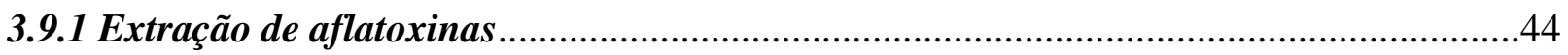

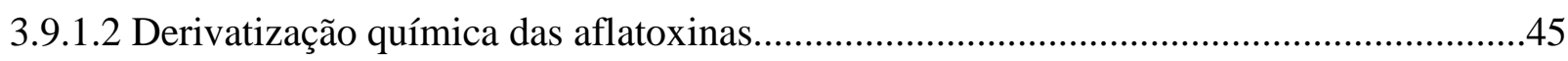

3.9.1.3 Cromatografia Líquida de Alta Eficiência (CLAE) paraseparação de aflatoxinas.........45

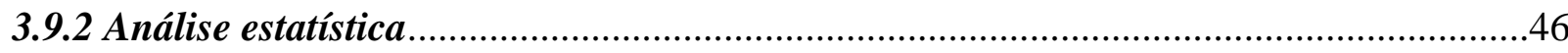

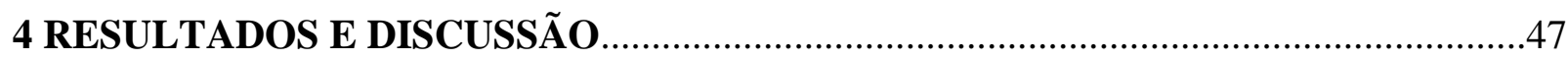

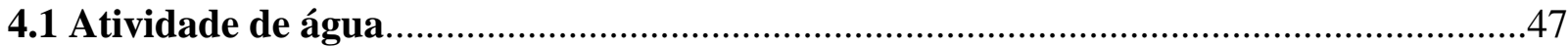

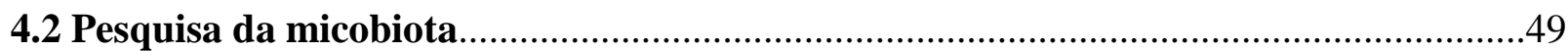

4.3 Efeito da Radiação gama e feixe de elétrons em aflatoxinas.......................................51

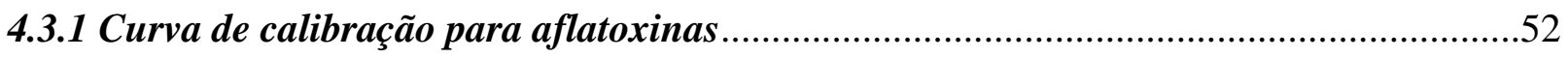

4.3.2 Limites de detecção e quantificação para aflatoxinas........................................................51

4.3.3 Teste de recuperação para aflatoxinas.........................................................................52

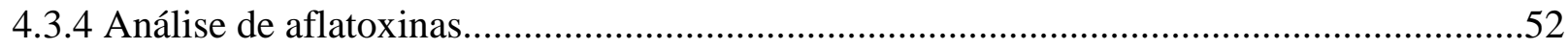

4.3.4.1 Feixe de Elétrons e Radiação gama...............................................................................53

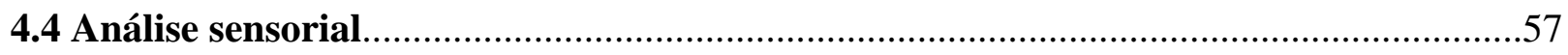

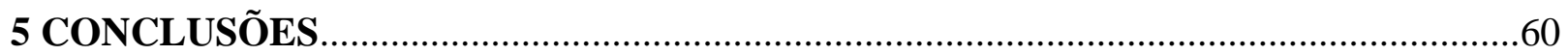

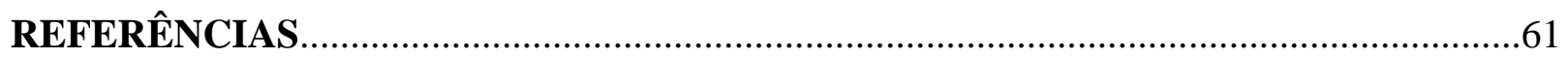

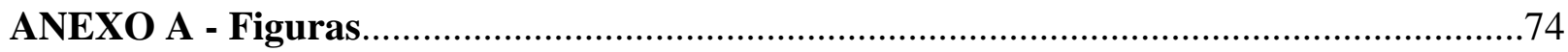

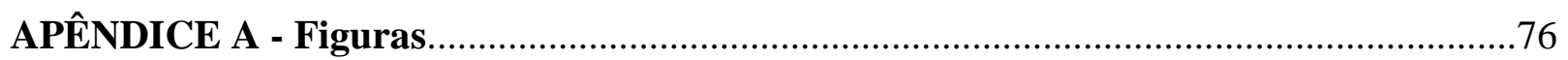

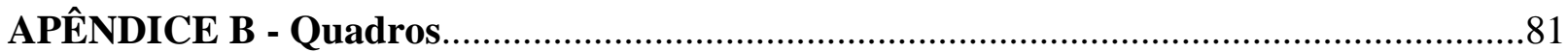

APÊNDICE C - Modelo de ficha de análise sensorial........................................................85 


\section{INTRODUÇÃO E REVISÃO DA LITERATURA}

\subsection{Castanheira}

A Castanheira (Bertholletia excelsa H.B.K) é uma árvore procedente das matas de vários países da região Amazônica (Anexo A, figura 1A) como Suriname, Guiana Francesa, Guiana, Peru, Venezuela, Colômbia, Bolívia e Brasil. As castanheiras cobrem uma superfície de aproximadamente 325 milhões de hectares, no entanto, as formações mais densas ocorrem no Brasil, principalmente nos Estados do Acre, Rondônia, Pará, Amapá, Amazonas, Mato Grosso e Goiás (CLAY; CLEMENTE, 1993; LORENZI, 2010; STOIAN et al., 2004).

Os castanhais são formações arbóreas altas e densas que se apresentam como uma floresta, onde as castanheiras se encontram, geralmente, os castanhais estão na forma de árvores adultas e de grande porte, sendo encontrados em solos pobres, desestruturados, drenados e argilosos/argilo-arenosos (DUBOIS, 1996; PENNACCHIO, 2007).

$\mathrm{Na}$ Amazônia, as áreas produtoras de castanha-do-Brasil encontram-se em climas quentes e úmidos, com temperaturas médias anuais que variam entre 24,3 e $27,2{ }^{\circ} \mathrm{C}$, demonstrando valores máximos de 30,6 e $32,6{ }^{\circ} \mathrm{C}$, com mínimas entre 19,2 e $23,4{ }^{\circ} \mathrm{C}$. Já as médias anuais de precipitação variam entre 1400 e $2800 \mathrm{~mm}$ e umidade relativa entre $79 \%$ e 86\% (BAQUIÃO 2012; TONINI, 2008).

A castanheira é uma árvore que pode atingir 50m de altura e 2 metros de diâmetro de base, apresenta tronco cilíndrico, reto e liso, ramificando-se apenas na porção superior da copa. Na floração, durante o período de seca, entre os meses de novembro a fevereiro, apresenta flores brancas ou cremes (ALHO, 1999; LORENZI 2010).

A queda dos frutos (ouriços) se inicia na estação chuvosa, entre os meses de novembro a abril. Com a queda do fruto alguns roedores, como cutias e pacas, são capazes de romper o ouriço alimentando-se das amêndoas (sementes) de castanha, assim, deixando o excedente no chão da floresta, que pode brotar e perpetuar novas gerações (BAQUIÃO, 2012). Pesquisadores também atribuem a perpetuação dos castanhais aos índios, que plantavam castanhas nos seus roçados abertos na mata, sendo que a castanheira precisa de muita luz na sua fase inicial de crescimento para germinar e crescer (DUBOIS, 2004; NOGUEIRA, 2012).

O fruto, também conhecido como ouriço, apresenta-se em estado circular com espessura fibrosa e compacta, coloração castanho-escura e diâmetro de 10 a $12 \mathrm{~cm}$, contém de 10 a 25 sementes, as sementes tem entre 3,5 a $7 \mathrm{~cm}$ de comprimento e $2 \mathrm{~cm}$ de largura, 
com peso variando entre 4 a $10 \mathrm{~g}$, apresentam uma casca dura e irregular (triangular) e, em seu interior, a amêndoa e/ou castanha-do-Brasil (ALHO, 1999; CLEY; CLEMENTE, 1993; LORENZI, 2010).

As castanhas, após removidas dos ouriços (Anexo A, figura 2A), sofrem um processo de lavagem e triagem, visando remoção daquelas consideradas deterioradas e atrofiadas. Após, são submetidas a secagem e armazenamento, até serem comercializadas com casca ou descascadas (BAQUIÃO, 2012).

\subsection{Castanha-do-Brasil}

Após a decadência da borracha, a castanha-do-Brasil, da família das Lecythidaceae, passou a ser o principal produto de extrativismo e exportação da região norte do Brasil. Visando normatizar o comércio desse produto, foi proposto o Decreto Federal $n^{\circ}$ 5.975/06, que regulamenta o Código Florestal e a Política Nacional de Meio Ambiente estabelecendo, assim, regras sobre o Plano de Manejo Florestal Sustentável, supressão de vegetação, utilização de matéria-prima florestal, reposição florestal e licença para transporte de produtos florestais (BAQUIÃO, 2012).

A castanha-do-Brasil atualmente é o produto vegetal mais importante da Amazônia na parte ecológica, social, econômica e alimentar. A maior parte do produto é comercializado descascado, in natura, e desidratado como forma de melhor conservação. No Brasil, a tecnologia empregada para beneficiamento de alimentos não sofreu evoluções significativas, porém, ações governamentais de apoio à produção extrativista tem gerado resultados muito positivos, uma vez que as cooperativas e organizações têm mostrado maior poder de negociação, já que a cadeia produtiva, por ser muito frágil, depende de compradores que praticamente ditam o preço (PENNACCHIO, 2012; SOUZA, 1984).

A produção brasileira de castanha-do-Brasil no que se refere ao comércio, obedece dois fluxos, comércio interno e externo, essa relação tem se alterado para $70 \%$ a $75 \%$ de consumo interno e de $25 \%$ a $30 \%$ para a exportação. No caso de exportações do produto in natura, o principal destino é a Bolívia, seguida dos Estados Unidos, Peru, e da castanha beneficiada, Honk Kong, Europa e Austrália (BRASIL, 2010; PENNACCHIO, 2012).

Apesar de ter a maior área de concentração de castanhais, atualmente o Brasil perdeu seu posto de maior exportador mundial do produto para a Bolívia, que lidera o mercado. A Bolívia também está entre os países que mais importam castanha com casca da amazônia 
brasileira, isso se dá pela falta de políticas públicas que possibilitem tratar de forma eficaz a cadeia produtiva do produto no Brasil, além disso, redução de castanhais produtivos, escassez de políticas de incentivo à comercialização, dificuldades de atendimento às exigências fitossanitárias para a exportação (BRASIL, 2010; LORENZI, 2000; PENNACHIO, 2007).

\subsection{Valor nutricional da castanha-do-Brasil}

Segundo Gonçalves et al. (2002), a castanha-do-Brasil é uma amêndoa oleaginosa de elevado valor energético e nutricional, apresentando vários constituintes que, em consumo adequado, são considerados essenciais para uma ótima alimentação. Além da qualidade nutritiva, ela também é apreciada pelo sabor .

Estudos demonstram que a amêndoa da castanha-do-Brasil possui de 60 a $70 \%$ de lipídeos e aproximadamente 15 a $20 \%$ de proteínas de alto valor biológico, cerca de cinco vezes o valor proteico do leite bovino in natura. A presença da fração albumina, excelsina, faz a castanha ser considerada a único alimento completo de origem vegetal conhecido, sendo chamada como "carne vegetal". Dentre os aminoácidos essenciais e imprescindíveis presentes na castanha estão, a leucina, isoleucina, metionina, cisteína, lisina, triptofano, valina e treonina (PENNACCHIO, 2012; SOUZA; MENEZES, 2004).

A fração lipídica denominada ácidos graxos mono e poli-insaturados apresenta-se nas seguintes proporções: $37,75 \%$ de ácido linoleico e $37,42 \%$ de oleico, o que totaliza $75,17 \%$ dos ácidos graxos totais, e 24,83\% de ácidos graxos saturados como o palmítico 13,15\%, esteárico 10,36\% e araquidônico 1,32\% (GONÇALVES, 2002). Os ácidos graxos mono e poli-insaturados são capazes de diminuir o colesterol ruim do sangue (LDL) e aumentar o colesterol bom (HDL), ajudando a impedir o desenvolvimento de doenças cardiovasculares (LIMA, 2000).

O elevado índice de ácidos graxos insaturados presentes na amêndoa, a torna um alimento altamente perecível, principalmente decorrendo dos processos oxidativos aos quais esses lipídeos são expostos. Isso pode implicar na redução do valor nutricional e o surgimento de cheiro e sabor rançoso, principalmente se as castanhas estiverem comercializadas em locais de alta temperatura e umidade relativa (SILVA, 2010).

A amêndoa contém minerais que são importantes para o organismo humano, dentre eles estão o fósforo, cobre, potássio, zinco, magnésio, manganês, cálcio e vitaminas, 
especialmente vitamina $\mathrm{B}_{1}$, sendo que esse valor varia conforme a localização das árvores (FELBERG, 2004; GONÇALVES, 2002).

Outro constituinte presente na castanha é o selênio, referido como um importante antioxidante, responsável na prevenção de câncer e, também, envolvido no metabolismo da tireoide. Sua deficiência é associada a cardiomiopatias, distrofia muscular e desordem na reprodução em várias espécies animais, inclusive no ser humano, assim a ingestão, em quantidades adequadas, de castanha-do-Brasil vem sendo indicada para pessoas que buscam uma melhor qualidade de vida (ALEIXO, 2000; COUTINHO, 2002). Vale resaltar que a quantidade de selênio também varia amplamente conforme a localização das árvores (FRANK; BETANCOURT, 1981).

Tabela 1 - Composição centesimal e valor energético da castanha-do-Brasil comestível.

\begin{tabular}{lc}
\hline Componentes & $\begin{array}{c}\text { Castanha-do-Brasil } \\
\text { (Quantidade g. } 100 \mathrm{~g}^{-1} \text { ) }\end{array}$ \\
\hline Umidade & 3,10 \\
Lipídeos & 64,94 \\
Proteínas & 14,11 \\
Nitrogênio & 2,62 \\
Fibra alimentar & 8,02 \\
Carboidratos & 6,27 \\
Cinzas & 3,56 \\
Valor energético & 655,98 \\
\hline
\end{tabular}

Fonte: Freitas (2010).

É recomendada a ingestão diária de $55 \mu \mathrm{g}$ de selênio na alimentação de adultos, o limite máximo tolerado é de $400 \mu \mathrm{g}$ (NAN, 2004).

\subsection{Micotoxinas}

As micotoxinas compreendem um conjunto de substâncias tóxicas produzidas por fungos filamentosos, denominados bolores, que dependendo da quantidade encontrada nos alimentos, causam graves problemas à saúde humana e animal. O termo micotoxina tem a 
origem na palavra grega "mykes", que significa fungo, e do latim "toxicum", que significa veneno ou toxina. (BULLERMAN, 1979; GOLDBLATT, 1972; MOSS, 1998).

O metabolismo fúngico produz dois tipos de metabólitos, os primários, que são compostos indispensáveis para o seu crescimento (carbono, lipídios e açúcares) e os secundários que são produzidos por várias espécies de fungos durante o crescimento exponencial, como os antibióticos, quinonas e micotoxinas, assim considerados produtos de biossíntese fúngica (BU'LOCK, 1980; STEYN, 1977).

As micotoxinas são metabólitos secundários orgânicos de baixo peso molecular, complexos, com elevada toxicidade a microrganismos, plantas e animais, podem ser voláteis, parcialmente voláteis ou não voláteis e contaminam alimentos no campo, durante o armazenamento ou após o processamento (MOSS, 1989).

Atualmente cerca de 400 tipos de micotoxinas são conhecidas, porém, apenas algumas delas são profundamente estudadas (ETZEL, 2002).

O problema da contaminação por micotoxinas já existe há muito tempo, e provavelmente vários surtos de micotoxicoses foram confundidos com pragas, envenenamentos e epilepsia. No antigo testamento, as 10 pragas do Egito, relatadas nos livros do Êxodo e Jó, há evidências da presença de micotoxinas nos alimentos. Supõe-se que uma das pragas lançadas contra os egípcios estivesse relacionada com a presença de micotoxinas, já que a contaminação dizimou rebanhos e a peste induziu tumores e úlceras nos e no povo egípcio. Inúmeros outros relatos de intoxicação por micotoxinas são citados durante a Idade Média, Moderna e Contemporânea na Europa e Ásia (SABINO, 2004). Em 1985, ocorreu o episódio chamado de "fogo de Santo Antonio", no qual a ingestão de centeio infectado por Claviceps purpurea foi relacionado a características de ergotismo. O ergotismo matou milhares de pessoas na Europa nos últimos mil anos, levantando a possibilidade do perigo de metabólitos tóxicos produzidos por fungos (PITT, 2012; SANTURIO, 2000). Já no Japão, muitas mortes foram associadas à ingestão de arroz contaminado por Penicillium spp. (SAITO et al., 1971) e, na Rússia, a ingestão de toxinas produzidas por Fusarium sporotrichioides causou ulcerações necróticas e estomatites na população (CAMPBELL; STOLOFF, 1974).

Os fungos produtores de micotoxinas podem crescer e produzir toxinas em produtos agrícolas, no campo ou armazenamento, durante o transporte, na indústria ou em qualquer momento da fase de consumo, quando a exposição às toxinas ocorre predominantemente pela ingestão de alimentos contaminados. Desta forma, as micotoxinas podem entrar na dieta humana e animal por meio de contaminação direta ou indireta dos alimentos, mantendo sua 
atividade biológica por longos períodos (CHU, 1991; JAY, 1994; RAMAKRISHNA; LACEY; SMITH, 1991).

A produção de micotoxinas pelos fungos vai depender da susceptibilidade do substrato, presença de macro e micronutrientes e fatores físicos como temperatura do ambiente, atividade de água do substrato, pH do substrato, umidade relativa do ar, aeração, danos mecânicos e tempo de armazenamento do produto. Existem, também, fatores biológicos como quantidade de esporos viáveis, capacidade genética do fungo em produzir micotoxinas, interação de diferentes fungos existentes no mesmo substrato, interação de micotoxinas e presença de parasitas (insetos, roedores e ácaros) (CIEGLER, 1978; MILLER, 1994).

De acordo com Cast (2003) e Hussein e Brasel (2001), a contaminação de alimentos por micotoxinas pode acarretar perdas econômicas de milhões de dólares, associadas ao impacto para a saúde humana, produtividade animal e também ao comércio internacional destes produtos, já que muitos países estabeleceram limites máximos para micotoxinas em alimentos. Os principais substratos suscetíveis à contaminação por micotoxinas, especialmente aflatoxinas, incluem o amendoim, milho, sementes de algodão e castanhas, especialmente, a castanha-do-Brasil (AMORIM et al., 2000; JELINEK , 1987).

No Brasil a Resolução - RDC n 7, de 18 de fevereiro de 2011 da Agência Nacional de Vigilância Sanitária, dispõe sobre os limites máximos tolerados (LMT) para micotoxinas em alimentos.

\subsection{Aspergillus flavus}

O gênero Aspergillus foi descrito inicialmente em 1729 pelo botânico Pier Antonio Michelli, porém, foi só em 1809 que Johan Heirich Friedrich definiu o gênero de forma mais clara, mas com o avanço da microscopia óptica em 1856, Rudolf Virchow apresentou as características micromorfológicas de Aspergillus spp. (BENNET, 2009; MACKENZIE, 1988; SMITH; ROSS, 1991).

Embora o gênero Aspergillus contenha mais de 260 espécies já estudadas, sua sistemática ainda esta amplamente em estado de fluxo, sempre evoluindo (SAMSOM; VARGA, 2009).

As espécies do gênero Aspergillus estão entre as mais importantes na deterioração de alimentos, estas se caracterizam pelo desenvolvimento de colônias coloridas e brilhantes e produção de conídios em cabeça tipo "mop-like" (escovão) (PITT; HOCKING, 2009). 
As principais espécies pertencentes a Aspergillus seção Flavi são: Aspergillus flavus, Aspergillus parasiticus, Aspergillus nomius, Aspergillus oryzae e Aspergillus sojae. Porém, o A. flavus, A. parasiticus e A. nomius recebem maior atenção pela capacidade de produção da micotoxina. Já as espécies A. oryzae e A. sojae são consideradas seguras, por não apresentarem histórico de produção de toxinas, sendo utilizadas na indústria alimentícia (PILDAIN; VAAMONDE; CABRAL, 2004; PITT; HOCKING, 2009).

A. flavus destaca-se por ser uma importante espécie produtora de aflatoxinas. As colônias de A. flavus apresentam características verdes e amarelo-oliva, eventualmente apresentando coloração amarelo puro, tornando-se acinzentadas com a idade (GEISEN, 2000).

Os conidióforos de A. flavus surgem a partir de hifas vegetativas septadas. As fiálides podem surgir de uma vesícula globosa (unisseriada) ou da métula que envolve a superfície da vesícula (bisseriada) (KORALIS-BURELLE et al., 1997).

A. flavus é mundialmente distribuído em solo, ar (anemófilo), materiais orgânicos e plantas, invadindo pré ou pós-colheita, podendo causar assim a contaminação fúngica e consequente produção de aflatoxinas (COTTY et al., 1994).

Segundo Lindsey e Turner (1975), os fungos anemófilos participam da contaminação de grãos na etapa do campo contaminando as partes aéreas das plantas durante seu desenvolvimento.

A contaminação fúngica inicia-se no campo e segue durante a coleta, secagem e armazenamento do substrato. O gênero Aspergillus spp. é amplamente distribuído e ocorre em maior frequência em regiões tropicais e subtropicais com alta umidade, porém, tem a capacidade de crescer em condições de altas temperaturas e baixa atividade de água, assim contaminando uma extensa variedade de substratos, sendo assim encontrado no período de armazenamento (BENNET; KLICH, 2003; CHOURASIA; ROY, 1991; PITT; HOCKING, 2009). Segundo Mello e Scussel, 2007, e Baquião, 2012, a contaminação fúngica pode acontecer no campo e segue durante o armazenamento e transporte dos frutos até o processamento.

Os fungos toxigênicos são aqueles capazes de produzir micotoxinas, sendo adaptados, em condições favoráveis, a colonizar, crescer e produzir toxinas, em uma variedade de substratos, conforme a exigência de cada espécie (STOLOFF, 1979).

A. flavus se desenvolve bem em substratos oleaginosos, onde apresentam maior capacidade de produção de aflatoxinas. Podem também produzir aflatoxinas em menor 
frequência em substratos ricos em amido como o milho (CASTRO et al., 1995; LACEY; MAGAN, 1991; POZZI et al., 1995; XAVIER et al., 1991).

A atividade de água (Aa) de um alimento é descrita como a quantidade de água livre disponível, ou seja, a água que não é comprometida com ligações químicas, dissoluções de solutos e outros (TANIWAKI; SILVA, 2001). Os valores de atividade de água oscilam entre 0 e 1 , sendo 1 o valor encontrado na água. Todos os fungos toxigênicos apresentam valores mínimo, ótimo e máximo de Aa para o seu crescimento (JAY, 1994), sendo que a maioria cresce em uma atividade de água em torno de 0,85 (TANIWAKI; SILVA, 2001). Segundo Lacey (1991), os valores mínimos de Aa para o crescimento de A. flavus encontram-se na faixa de 0,78 a 0,82 .

A umidade relativa do ar de $80 \%$ a $90 \%$ e temperatura acima de $25{ }^{\circ} \mathrm{C}$ favorecem o crescimento e desenvolvimento de A. flavus, sendo que o crescimento ótimo deste fungo ocorre a uma temperatura em torno de $35^{\circ} \mathrm{C}$ (CAST, 2003; CHRISTENSEN; SAUER, 1982).

A espécie A. flavus destaca-se por ser a uma das mais importantes produtora das aflatoxinas, sendo capaz de sintetizar as aflatoxinas B $_{1}$ e B $_{2}$ (PITT; HOCKING, 1997).

\subsection{Aflatoxinas}

Em 1960 mais de 100 mil perus morreram nas fazendas da Inglaterra, com uma doença aparentemente nova, inicialmente denominada "Turkey X Disease", logo descobriram que a doença não se limitou aos perus, mas outras aves também foram afetadas. Depois de um cuidadoso estudo visando encontrar os focos iniciais da doença, descobriram que ela estava associada a lotes de farelo de amendoim exportado pelo Brasil que foi consumido por essas aves. Após uma análise detalhada dos lotes de farelo suspeitos, foi descoberto que esse produto era altamente tóxico para os animais, a partir daí surgiram várias especulações na Inglaterra sobre a natureza da toxina, porém apenas em 1961 foi identificado o A. flavus como o produtor da aflatoxina, nome dado devido à sua origem (A. flavus - Afla) (ANSCI, 2012; BLOUNT, 1961). A partir daí vários estudos foram realizados envolvendo as aflatoxinas.

Em 1961 surgiu o primeiro estudo sobre o efeito carcinogênico da aflatoxina, onde observou-se o desenvolvimento de tumores malignos em ratos que consumiram ração contaminada com a toxina em doses baixas, diferentes das doses que causavam intoxicações agudas (LANCASTER; JENKINS; PHILIP, 1961). 
De acordo com a FAO estima-se que cerca de $25 \%$ dos alimentos consumidos mundialmente apresentam contaminação por micotoxinas, das quais a mais notória são as aflatoxinas. O prejuízo anual é de aproximadamente 1 bilhão de dólares, incluindo gastos com saúde humana, animal e produtos agrícolas contaminados (CAST, 2003).

As aflatoxinas (Figura 1), quimicamente apresentam um núcleo cumarínico fundido a um anel bifurano e um anel pentanona ou 6-lactona (APPLEBAUM et al., 1982). São conhecidas 17 substâncias do grupo, porém, as aflatoxinas $B_{1}, B_{2}, G_{1}$ e $G_{2}$ são as mais importantes em alimentos, sendo a toxina $B_{1}$ a mais tóxica do grupo, seguida das $G_{1}, B_{2}$ e $G_{2}$. As aflatoxinas receberam essas denominações $B$ e $G$ devido às suas características fluorescentes quando expostas à radiação ultravioleta: B - blue e G - green (HARTLEY e O'KELLEY, 1963; WYLLIE; MOREHOUSE, 1997).

Figura 1 - Estrutura química das aflatoxinas $\mathrm{B}_{1}, \mathrm{~B}_{2}, \mathrm{G}_{1}$ e $\mathrm{G}_{2}$.

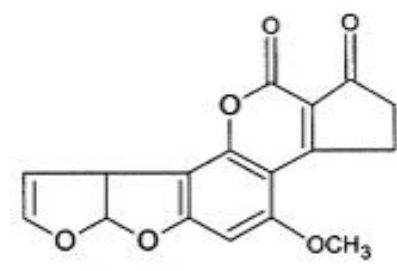

Aflatoxina $\mathrm{B}_{1}$<smiles>COc1cc2c(c3oc(=O)c4c(c13)CCOC4=O)C1C=COC1O2</smiles>

Aflatoxina $\mathrm{G}_{1}$

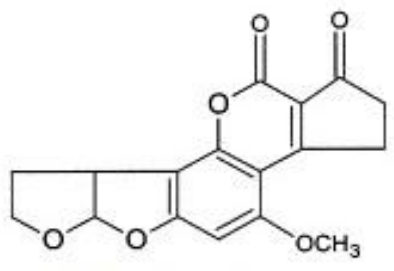

Aflatoxina $\mathrm{B}_{2}$<smiles>COc1cc2c(c3oc(=O)c4c(c13)CCOC4=O)C1CCOC1O2</smiles>

Aflatoxina $\mathrm{G}_{2}$

Fonte: Zain (2011).

As aflatoxinas são hepatotóxicas e podem causar injúrias no fígado. $\mathrm{AFB}_{1}$ foi descrita como o mais potente agente hepatocarcinógeno em mamíferos, sendo que os efeitos tóxicos das aflatoxinas ocorrem após a ativação metabólica por enzimas hepáticas de suas moléculas, principalmente no retículo endoplasmático liso e no citoplasma (HUSSEIN; BRASEL, 2001; IARC, 1993). Podem causar danos como hemorragias, edemas, imunossupressão e carcinoma hepático (SMITH; ROSS, 1991). 
$A$ aflatoxina $B_{1}$ quando presente em ração, pode ser ingerida por animais e sofrer biotransformação, transformando-se em aflatoxina $\mathrm{M}_{1}\left(\mathrm{AFM}_{1}\right)$. Assim, existe o risco de exposição humana às aflatoxinas através da ingestão de alimentos diretamente contaminados, ou através da ingestão indireta, com o consumo de leites e carnes contaminadas com $\mathrm{AFM}_{1}$ (MOSS, 1989; PEREIRA et al., 2005).

Segundo a Organização Mundial da Saúde (1983), as aflatoxinas são metabólitos lipossolúveis, de baixo peso molecular, solúveis em solventes como clorofórmio e metanol. São relativamente sensíveis à luz e apresentam, no caso $\mathrm{AFB}_{1}$, ponto de fusão de $269{ }^{\circ} \mathrm{C}$. Essas toxinas podem ser absorvidas pela pele, pulmão e trato gastrintestinal, sendo distribuídas para rins, tecido adiposo e músculos, tendo maior concentração no fígado.

Almeida e Azevedo (1950), Arrus et al. (2005), Baquião (2012), Bitancourt (1949) e Lin e Dianese (1976), revelaram a presença A. flavus em castanha-do-Brasil, isolando também cepas aflatoxigênicas deste fungo. Trabalhos realizados por Marklinder et al. (2005) e Steiner et al. (1992), também demonstraram a ocorrência de aflatoxinas em castanha-doBrasil.

A ocorrência de aflatoxinas em castanha-do-Brasil tem sido confirmada por vários estudos e constitui um problema para a exportação da castanha-do-Brasil, desde 1998, quando a União Europeia restringiu os limites de tolerância de aflatoxinas total e $\mathrm{AFB}_{1}$ para 4 e 2 ng/g, respectivamente (ARRUS et al., 2005; FREIRE et al., 2000; STEINER et al., 1992). Além disso, ocorreu devolução de lotes de castanha-do-Brasil por países importadores devido ao alto nível de contaminação por toxinas, a União Europeia passou a exigir condições especiais para a compra do produto, dentre elas o atendimento às boas práticas extrativistas e a determinação dos teores de aflatoxinas por laboratórios credenciados junto ao Ministérios da Agricultura, Pecuária e Abastecimento (MAPA). O MAPA, então, começou a elaborar programas de monitoramento da cadeia produtiva da castanha-do-Brasil, visando prevenir e controlar a contaminação (BRASIL, 2000).

Atualmente no Brasil a Resolução - RDC n 7, de 18 de fevereiro de 2011 da Agência Nacional de Vigilância Sanitária, dispõe sobre os limites máximos tolerados (LMT) para micotoxinas em alimentos. Para aflatoxinas $B_{1}, B_{2}, G_{1}$ e $G_{2}$ os limite máximo tolerado para castanha-do-Brasil sem casca para o consumo direto é de $10 \mu \mathrm{g} / \mathrm{kg}$.

Segundo Scott (1990), existem vários métodos para a detecção de aflatoxinas como a cromatografia em cama delgada (CCD), a cromatografia líquida de alta eficiência (CLAE), a cromatografia gasosa (CG) e ELISA. 
A. flavus destaca-se como mais importante produtora de aflatoxinas, capaz de sintetizar as $\mathrm{AFB}_{1}$ e $\mathrm{AFB}_{2}$, já a espécie A. parasiticus sintetiza $\mathrm{AFB}_{1}, \mathrm{AFB}_{2}, \mathrm{AFG}_{1}$ e $\mathrm{AFG}_{2}$ (PITT; HOCKING, 1997; SMITH; ROSS, 1991).

Segundo Lacey (1991), as faixas de temperatura e de atividade de água (Aa) necessárias para o crescimento destes fungos são de 6 a $45{ }^{\circ} \mathrm{C}$ e de 0,78 a 0,80 , respectivamente, sendo a temperatura e a atividade de água ótimas de 35 a $37{ }^{\circ} \mathrm{C}$ e atividade de água de 0,95. Para a produção de micotoxinas, a Aa mínima varia de 0,83 a 0,87. As temperaturas mínima, ótima e máxima para a produção de aflatoxinas são 12, 27 e 40 a $42{ }^{\circ} \mathrm{C}$, respectivamente (OMS, 1983); favorecendo a contaminação em zonas tropicais e subtropicais. Em alimentos estocados a umidade relativa do ar de 80 a $85 \%$ e do substrato de $17 \%$, facilitam o crescimento do gênero Aspergillus e a produção de aflatoxinas, bem como a temperatura de armazenamento de 24 a $35^{\circ} \mathrm{C}$ (LEESON et al., 1995).

Recentemente vários trabalhos demonstraram a ocorrência de aflatoxinas em amêndoas de castanha-do-Brasil, como o de Pacheco et. al. (2010) que detectaram aflatoxinas em 7,5\% das amostras coletadas na cidade de Manaus. As amostras, oriundas das etapas de recepção e comercialização, revelaram concentrações de aflatoxinas de 8 a $686 \mu \mathrm{g} / \mathrm{kg}$.

Caldas et al. (2002), demonstraram que 33,3\% das amostras de castanha-do-Brasil estavam contaminadas com aflatoxinas.

Alguns trabalhos citam a aplicação de métodos para avaliar o grau de degradação de aflatoxinas e de contaminação fúngica. Neste sentido, estudos conduzidos por Scussel et al. (2011), avaliando a aplicação de métodos com atmosfera modificada (ozônio, dióxido de carbono e absorventes), revelaram degradação de aflatoxinas e inibição de crescimento da micobiota após aplicação de ozônio nas embalagens de castanha-do-Brasil armazenadas.

Segundo a Association of Official Analytical Chemists, a retirada das cascas e triagem das amêndoas deterioradas por fungos pode também contribuir para a redução de aflatoxinas em castanha-do-Brasil, assim como o processo de secagem, que tem como finalidade diminuir a Aa das amostras e controlar o crescimento fúngico e produção de aflatoxinas (AOAC, 2005; BITANCOURT, 1949; PACHECO; SCUSSEL, 2007; VARGAS et al., 2011).

A radiação ionizante vem sendo citada por diversos trabalhos como um valioso método utilizado para conservação de alimentos, principalmente com a aplicação de dose de 10 kGy. A irradiação de alimentos contribui imensamente no controle de perigos microbiológicos (AN-HUNG et al., 1995; FOOD AND DRUG ADMINISTRATION, 2012). 


\subsection{Radiação ionizante}

A radiação ionizante (raios X, radiação gama, feixe de elétrons) é a forma de radiação que apresenta energia suficiente para remover elétrons das órbitas dos átomos ou moléculas produzindo assim íons. Considerada radiação de alta energia, por causar ionização do meio em que é absorvida, difere da radiação não ionizante (microondas, ondas de rádio e TV) que não tem energia suficiente para ionizar o meio (RUSTOM, 1997).

A energia gasta na excitação e ionização de moléculas, gera reações químicas que podem modificar permanentemente a estrutura físico-química do material irradiado. A dose absorvida, ou simplesmente dose, é a quantidade de energia absorvida por unidade de massa do material irradiado. A unidade utilizada denomina-se Gray (Gy) ou quilogray (kGy) onde 1 Gy equivale à energia de 1 joule absorvido por $1 \mathrm{~kg}$ de material irradiado (CAMARGO; WALDER, 2012; DIEHL, 1992; SATIN, 1993).

A ideia do uso da radiação ionizante em alimentos surgiu logo após a descoberta da radioatividade por Henri Becquerel, em 1895. No mesmo ano foi sugerida, em publicação de um jornal de medicina da Alemanha, a utilização da radiação para o controle de microrganismos patogênicos em alimentos. No inicio de 1900, estudos realizados nos Estados Unidos e no Reino Unido descreveram o uso da radiação ionizante na destruição de microrganismos em alimentos. Naquela época, a única fonte de radiação ionizante era o rádio, que pela não disponibilidade, tornava o processo inviável comercialmente. Entretanto, há relatos de outros estudos utilizando raios-X para matar insetos e larvas em folha de tabaco e também parasitas encontrados na carne do porco. Com o surgimento de reatores nucleares a radiação ionizante passou a ser mais viável, e mais estudos foram feitos para a segurança das aplicações em alimentos. O primeiro país a conceder autorização para consumo humano de alimentos irradiados foi a antiga União Soviética, que autorizou em 1958 a irradiação de batatas para inibição do brotamento deste alimento (NORDION, 2012).

Através da radiação podem ser eliminados microrganismos patogênicos ao homem e animais, sendo utilizada principalmente para esterilização de produtos farmacêuticos e médicos e irradiação de alimentos, já na agricultura a radiação ionizante contribui para o controle de insetos e pragas em produtos agrícolas (TSAI, 2006).

O comitê de especialistas sobre radiação de alimentos formados pelos órgãos das nações unidas Food and Agriculture Organization (FAO), International Atomic energy Agency (IAEA) e a World Health Organization (WHO) e o codex geral de padrões para 
alimentos irradiados, fazem a recomendação sobre os tipos de radiação ionizante consideradas adequadas para a irradiação de alimentos: Raios- $\mathrm{X}$ com energia de até $5 \mathrm{MeV}$, Radiação gama originada dos radionuclídeos Cobalto $60\left({ }^{60} \mathrm{Co}\right)$ e Césio $\left({ }^{137} \mathrm{Cs}\right)$, Elétrons com energia de até $10 \mathrm{MeV}$ (DIEHL, 1992; FAO/IAEA, 1982).

Segundo Tsai (2006), a geração de raios- $X$ é feita em aceleradores, onde o feixe de elétrons incide sobre um alvo de material pesado gerando, por freamento, os raios $\mathrm{X}$, esse efeito é também conhecido como "efeito Bremsstralung". Esse tipo de gerador apresenta eficiência muito baixa, pois não mais que $10 \%$ da energia dos elétrons se convertem em energia na forma de ondas eletromagnéticas (raios x), assim a viabilidade da utilização de radiação por feixe de elétrons e radiação gama é maior.

Os isótopos que liberam constantemente radiação gama não podem ser ligados ou desligados como uma máquina de raio $\mathrm{X}$, assim a radiação gama e feixe de elétrons tem sido utilizada para esterilização de alimentos e insumos médicos, e novos equipamentos vêm sendo projetados para essa finalidade (AQUINO, 2011; PELCZAR; CHAN; KRIEG, 1996).

Nem todos os tipos de radiação ionizantes são adequados para a irradiação de alimentos, porque não apresentam penetração suficiente no material, como por exemplo as partículas alfa (FERREIRA-CASTRO, 2011).

Figura 2 - Penetrabilidade da radiação ionizante, partículas $\alpha, \beta$ (Elétrons) e raios gama.

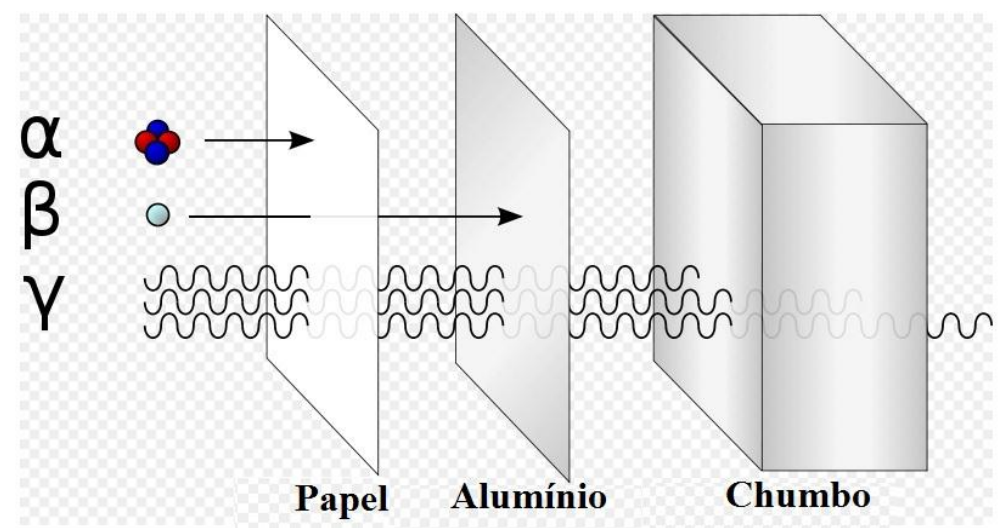

Fonte: Modificado de Wikimedia (2012).

A penetrabilidade das radiações ionizantes é inversamente proporcional a densidade do produto beneficiado, a espessura e a densidade do material a ser tratado é importante para a aplicação da radiação gama ou feixe de elétrons, onde o poder de penetração do feixe de elétrons é menor que o do raio gama, por exemplo, em um material com densidade de 1 $\mathrm{g} / \mathrm{cm}^{3}$ (semelhante a água) o poder de penetração de um feixe de elétrons com energia de 10 
$\mathrm{MeV}$ é de $5 \mathrm{~cm}$, enquanto que utilizando a radiação gama com cobalto-60 e energia média de 1,25 MeV é de cerca de $50 \mathrm{~cm}$ (SATO, 1993; TSAI, 2006).

Em tecnologia de alimentos são preconizadas técnicas para a preservação de alimentos, neste sentido, a irradiação de alimentos pode ser empregada isoladamente ou em conjunto com outras tecnologias como: resfriamento, congelamento, aquecimento e embalagem (WIENDL, 1997).

As radiações utilizadas no processamento de alimentos não possuem energia suficiente para provocar qualquer reação nuclear na matéria, ou seja, não reagem com núcleo dos átomos dos materiais, portanto não deixam nenhum resíduo radioativo no material após a irradiação, assim o alimento ou qualquer outro material submetido a essas radiações, não se tornam radioativos (IAEA; FAO; WHO, 2012; MAXY, 1992; OKUNO, 1998).

\subsubsection{Radiação Gama}

O tratamento com radiação gama é baseado em ondas eletromagnéticas de alta frequência, liberadas por radioisótopos como o cobalto-60 $\left({ }^{60} \mathrm{Co}\right)$ e o césio-137 $\left({ }^{137} \mathrm{Cs}\right)$, este último utilizado no tratamento de câncer, na investigação de camadas subterrâneas de poços de petróleo, etc. (ENVIRONMENTAL PROTECTION AGENCY, 2012) .

$\mathrm{O}{ }^{60} \mathrm{Co}$, formando quando o ${ }^{59} \mathrm{Co}$ absorve um nêutron adicional, tem meia vida de 5,261 anos, ou seja, há um decaimento da atividade do radioisótopo de 12,34\% ao ano, assim é necessário periodicamente reabastecer as fontes (Apêndice A, figura 1.AP) com o isótopo para manter sua capacidade (CALVO, 2005; DIEHL, 1995).

Segundo Tsai (2006), o cobalto-60, empregado na indústria no processo de esterilização, tem como vantagem a produção de radiação gama com alta penetrabilidade e uniformidade da dose, permitindo o tratamento de produtos de diferentes tamanhos e formatos. A não utilização do Césio-137 como fonte industrial para irradiação de alimento se dá também principalmente pela preocupação ambiental, devido este ser um sal solúvel e de fácil contaminação. A legislação brasileira permite para a irradiação de alimentos uso de fontes de cobalto-60 e césio-137 e aceleradores de elétrons (DIEHL, 1992; SABATO, 2005).

Os materiais são colocados no interior do irradiador tendo como fonte o ${ }^{60} \mathrm{Co}$, e a radiação gama penetra, por exemplo, o alimento e sua embalagem, porém a maior parte dela apenas passa pelo produto, similar às microondas, sem deixar resíduos. A esterilização com raios gama é mais demorada do que a com feixe de elétrons, porém tem capacidade de 
penetração muito maior que os elétrons de alta energia (SPOLAORE et al., 2003; TSAI, 2006).

Os irradiadores com fontes de cobalto-60 e césio-137 foram inicialmente mais utilizados nos processos de radiação, devido a simplicidade e confiabilidade do processamento, porém, atualmente o tratamento com feixe de elétrons vem sendo muito utilizado, principalmente pela preocupação ambiental e de radioatividade (TSAI, 2006).

\subsubsection{Radiação por feixe de elétrons}

Um acelerador de partículas é definido como um equipamento que aplica forças as partículas carregadas por meio de alguma combinação de campos elétricos e magnéticos, gerando íons com alta velocidade e alta energia, quando se estabelece um potencial de alta voltagem entre um cátodo e um ânodo, no vácuo, o cátodo emite feixe de elétrons, seguindo o mesmo princípio do tubo de televisão (Apêndice A, figura 2.AP), porém, o tubo de televisão utiliza aproximadamente 25.000 volts de energia, já para aceleradores industriais esta tensão varia entre 200.000 volts a 10.000.000 de volts (BORRELY, 1995; TSAI, 2006).

Os aceleradores de elétrons não foram inicialmente utilizados para processos de esterilização devido às dificuldades de serem controlados, pelo número de variáveis envolvidas como: energia, varredura, largura, intensidade do feixe, velocidade da esteira; esses fatores influenciavam na dose absorvida. Outros fatores se davam pelo fato das máquinas apresentarem sistemas eletrônicos complexos, e que poderiam precisar de reparos mais constantes, porém com o avanço da tecnologia dos aceleradores industriais, visando adaptá-los para atender a rotina de irradiação dos produtos, tornou-se mais viável a utilização desse processo (SPINKS; WOODYS, 1990; TSAI, 2006).

Segundo Silva et al. (2011), os aceleradores de elétrons são bastante utilizados no processamento industrial, principalmente na preservação e desinfestação de alimentos. Apresentam elevada capacidade de processamento, custo favorável e a possibilidade de interrupção das fontes de radiação. Diferentemente da radiação gama, o emprego de feixes de elétrons, destaca-se pela rapidez no processamento de materiais.

Os aceleradores de elétrons são projetados e fabricados para usos específicos, sendo classificados pela faixa de energia, sendo que os aceleradores com faixa entre 0,3 a $10 \mathrm{MeV}$ são os mais utilizados para aplicação industrial (SATO, 1993).

Quadro 1 - Comparação entre radiação gama e por feixe de elétrons 


\begin{tabular}{|c|c|c|}
\hline Tipo de radiação & Vantagens & Desvantagens \\
\hline Radiação gama & $\begin{array}{l}\text { - Boa Penetração. } \\
\text { - Baixo consumo de energia } \\
\text { elétrica. } \\
\text { - Não requer operadores } \\
\text { especializados. }\end{array}$ & $\begin{array}{l}\text { - Não pode ser focado, } \\
\text { flexionado, com implicações na } \\
\text { eficiência. } \\
\text { - Não pode ser desligado. } \\
\text { - Dificuldades para } \\
\text { licenciamento } \\
\text { - Recarga e transporte da fonte }\end{array}$ \\
\hline Feixe de elétrons & $\begin{array}{l}\text { - Condução do material a ser } \\
\text { exposto mais facilitada. } \\
\text { - Pode ser focado, flexionado } \\
\text { com maior flexibilidade na } \\
\text { eficiência } \\
\text { - Pode ser desligado (menor } \\
\text { desperdício) } \\
\text { - Não utiliza material } \\
\text { radioativo }\end{array}$ & $\begin{array}{l}\text { - Baixo poder de } \\
\text { penetrabilidade. } \\
\text { - Alto consumo de energia. } \\
\text { - Necessita de operadores } \\
\text { capacitados. } \\
\text { - Custo do equipamento e } \\
\text { instalações. }\end{array}$ \\
\hline
\end{tabular}

Fonte: (BORRELY, 1995; TSAI, 2006).

$\mathrm{Na}$ escolha do processo de radiação ionizante a ser utilizado, precisam ser avaliados esses itens do Quadro 1, de acordo com as necessidades de cada caso (SABATO, 2005).

\subsubsection{Efeitos da radiação ionizante}

A radiação ionizante é capaz de causar vários efeitos ao meio no qual se difundem, através de vários processos de interação.

\subsubsection{Radiólise da água}

A água está presente em todos os alimentos, com percentual de aproximadamente 90\% nos vegetais, $80 \%$ nas frutas, $60 \%$ em carnes e $40 \%$ em pães. Até os produtos considerados mais secos apresentam água, como: farinha de trigo 13\%, vegetais desidratados 
$10 \%$, e $5 \%$ para castanhas (nozes). A radiólise da água ocorre quando a radiação ionizante entra em contato com a água, esse processo é de extrema importância para a irradiação de alimentos (DIEHL, 1995; WHO, 1994).

Os primeiros estudos avaliando os efeitos da radiólise da água foram descritos por Giesel e Marie Curie,em 1902, porém, só em 1909 que Kernbaum relatou a produção de peróxido de hidrogênio (GIESEL, 1902; KERNBAUM, 1909). Debierne foi o primeiro a levantar a hipótese de que a radiólise da água produzia átomo de hidrogênio $(\cdot \mathrm{H})$ e o radical hidroxila $(\cdot \mathrm{OH})$, porém, apenas com o avanço das pesquisas em radiação química, principalmente durante a segunda guerra mundial, foi que a radiólise da água foi amplamente estudada, principalmente nos Estados Unidos (CAER, 2011).

A produção de radicais livres provenientes da água intracelular, são responsáveis por danos celulares, ou seja, a desidratação favorece a radiorresistência dos microrganismos (CORRE; VENAILLE, 1988).

Segundo Buxton (1987), Diehl (1995) e Spinks (1990), os produtos da radiólise da água são:

$\mathbf{e}_{\mathbf{a q}}^{-}$- Elétron aquoso ou hidratado

- OH - Radical hidroxila

-H - Átomo de hidrogênio

$\mathbf{H}_{2}$ - Hidrogênio

$\mathbf{H}_{2} \mathbf{O}_{2}$ - Peróxido de hidrogênio

$\mathbf{H}_{3} \mathbf{O}^{+}\left(=\mathrm{H}^{+}{ }_{\mathrm{aq}}\right)$ - Próton hidratado

$\mathbf{H O}_{2}$ - Hidroperóxido

$\mathbf{H}_{2} \mathrm{O} \rightarrow$ Radiação ionizante $\rightarrow \mathbf{e}^{-}{ }_{\text {aq }} \cdot \cdot \mathbf{O H}, \cdot \mathbf{H}, \mathrm{HO}^{\cdot}{ }_{2}, \mathrm{H}_{3} \mathrm{O}^{+}, \mathbf{O H}^{-}, \mathbf{H}_{2} \mathbf{O}_{2}, \mathbf{H}_{2}$

$\mathrm{O}$ radical hidroperoxila $\left(\mathrm{HO}_{2}\right)$ é pouco produzido. A hidroxila $(\cdot \mathrm{OH})$, o elétron aquoso $\left(\mathrm{e}_{\mathrm{aq}}^{-}\right)$e o átomo de hidrogênio $(\cdot \mathrm{H})$ são altamente reativos, o hidrogênio $\left(\mathrm{H}_{2}\right)$ e peróxido de hidrogênio $\left(\mathrm{H}_{2} \mathrm{O}_{2}\right)$ são endoprodutos da radiólise da água muito estáveis, sendo amplamente consumidos durante o processo, como demonstrado na seguinte reação:

$$
\begin{aligned}
& \mathrm{H}_{2} \mathrm{O}_{2}+\mathrm{e}_{\text {aq }}^{-} \rightarrow \cdot \mathrm{OH}+\mathrm{OH}^{-} \\
& \mathrm{H}_{2}+\cdot \mathrm{OH} \rightarrow \mathrm{H}_{2} \mathrm{O}+\cdot \cdot \mathrm{H}^{-}
\end{aligned}
$$


Eles são produzidos em baixas quantidades, mesmo em doses de radiação muito altas, a saturação da água com o oxigênio pode aumentar a produção de $\mathrm{H}_{2} \mathrm{O}_{2}$, a formação desses produtos tem grande significado na irradiação de alimentos já que o $\mathrm{H}_{2} \mathrm{O}_{2}$ é um agente oxidante, o radical hidroxila $(\cdot \mathrm{OH})$ é também conhecido como um poderoso agente oxidante, e o $\mathrm{e}_{\mathrm{aq}}^{-}$é um forte agente redutor e o $\cdot \mathrm{H}$ é um agente redutor menos efetivo. Considerando que todos os alimentos contem substâncias que podem ser oxidadas ou reduzidas, as reações descritas anteriormente são esperadas quando os alimentos que contêm água são irradiados (DIEHL, 1995).

\subsubsection{Efeito da diluição}

Quando uma solução diluída é irradiada, ocorre aumento da radiossensibilidade, processo conhecido como efeito da diluição. Assim, quando a solução diluída é irradiada, a extensão da degradação do soluto depende do número de radicais reativos disponíveis para a reação com as moléculas do soluto. A pectinase (enzima) apresenta uma alta radiorresistência quando irradiada em estado seco, mas é inativada quando irradiada em soluções (FARKAS, 1985).

\subsubsection{Influência do oxigênio}

A presença ou ausência de oxigênio durante a irradiação tem uma importância muito grande durante a radiólise. A água, em equilíbrio com o oxigênio do ar, contem baixas concentrações de oxigênio, átomos de hidrogênio podem reduzir o oxigênio formando o radical hidroperóxido $\left(\cdot \mathrm{HO}_{2}\right)$, que é um agente oxidante fraco (CAER, 2011; WHO, 1994; DIEHL, 1995).

$$
\cdot \mathbf{H}+\mathrm{O}_{2} \rightarrow \cdot \mathbf{H O}_{2}
$$

Em equilíbrio com o radical ânion superóxido:

$$
\cdot \mathbf{H O}_{2} \leftrightarrow \mathbf{H}^{+}+\cdot \mathbf{O}_{2}^{-}
$$

Outro caminho para a formação do radicação superóxido $\left(\cdot \mathrm{O}_{2}^{-}\right)$é a reação de elétron aquoso com oxigênio:

$$
\mathbf{e}_{\mathrm{aq}}^{-}+\mathrm{O}_{2} \rightarrow \cdot \mathbf{O}_{2}^{-}
$$


Com a remoção dos agentes redutores elétron aquoso e átomo de hidrogênio $\left(\mathrm{e}_{\mathrm{aq}}^{-} \mathrm{e}\right.$ $\cdot \mathrm{H})$, a importância do radical $\cdot \mathrm{OH}$ e das reações de oxidação tornam-se maiores em soluções oxigenadas. Ambos radicais hidroperóxido e superóxido $\left(\cdot \mathrm{OH}_{2}\right.$ e $\left.\cdot \mathrm{O}_{2}{ }^{-}\right)$podem causar o aumento do peróxido de hidrogênio $\left(\mathrm{H}_{2} \mathrm{O}_{2}\right)$ :

$$
\begin{gathered}
2 \cdot \mathrm{HO}_{2} \rightarrow \mathrm{H}_{2} \mathrm{O}_{2}+\mathrm{O}_{2} \\
\cdot \mathrm{O}_{2}^{-}+\cdot \mathrm{HO}_{2}+\mathrm{H}^{+} \rightarrow \mathrm{H}_{2} \mathrm{O}_{2}+\mathrm{O}_{2}
\end{gathered}
$$

A radiossensibilidade das bactérias é menor em condições de anaerobiose, em contrapartida o efeito letal das radiações ionizantes aumenta na presença de oxigênio, por causa da oxidação dos lipídios de membrana, que reduz a energia e material necessário para a reparação celular (CORRE; VENAILLE, 1988).

Como demonstrado, muitos outros radicais são produzidos quando os alimentos são irradiados. O oxigênio pode acrescentar alguns dos radicais, levando ao aumento de radicais peróxidos (GRANT et al., 1991).

\subsubsection{Influência da temperatura}

Segundo Diehl (1995) e Ley (1970), durante a irradiação, a temperatura também é um fator determinante para provocar mudanças radiolíticas. $\mathrm{O}$ frio (congelamento) promove um efeito protetor aos efeitos da radiólise. Assim, um material a $-2{ }^{\circ} \mathrm{C}$ quando submetido à irradiação tende a apresentar maior difusão de moléculas e radicais livres, se comparado a -10 ${ }^{\circ} \mathrm{C}$. A radiólise da água, interrompida em materiais congelados, são, desta forma, mantidas inertes das reações entre os radicais ou com o substrato.

Quando o material alcança novamente a temperatura ambiente, os danos no substrato são muito menores do que em produtos não congelados, quando irradiados. O gelo funciona como radioprotetor, inibindo a formação de radicais livres (CORRE; VENNAILLE, 1988).

\subsubsection{Influencia do $\mathrm{pH}$}

$\mathrm{O} \mathrm{pH}$ do material a ser irradiado é um fator que pode influenciar o resultado do tratamento com radiação ionizante, devido ao equilíbrio das reações, em meio ácido ocorre o 
desaparecimento dos elétrons hidratados $(\cdot \mathrm{H})$, já em meio alcalino há um favorecimento da formação de elétron aquoso ( $\mathrm{e}_{\mathrm{aq}}^{-}$) (DIEHL, 1995).

1.7.3.6 Efeito direto e efeito indireto da radiação ionizante

Quando uma solução aquosa é irradiada, as moléculas do substrato podem ser primeiramente afetadas diretamente, e/ou mais tarde por reações com produtos provenientes da radiólise da água, esses dois mecanismos são chamados de efeitos diretos e efeitos indiretos da radiação (DIEHL, 1995; NUCLEAR REGULATORY COMMISSION (NRC, 2012).

A radiação ionizante quando aplicada em materiais biológicos, pode provocar efeitos direto em átomos da molécula de ácido nucléico, ou em algum outro componente crítico para a sobrevivência da célula, essa interação pode afetar a capacidade da célula de se reproduzir e, portanto, sobreviver. O efeito direto é o dominante quando esporos são irradiados (NRC, 2012).

Figura 3 - Exemplo efeito direto da radiação no DNA.

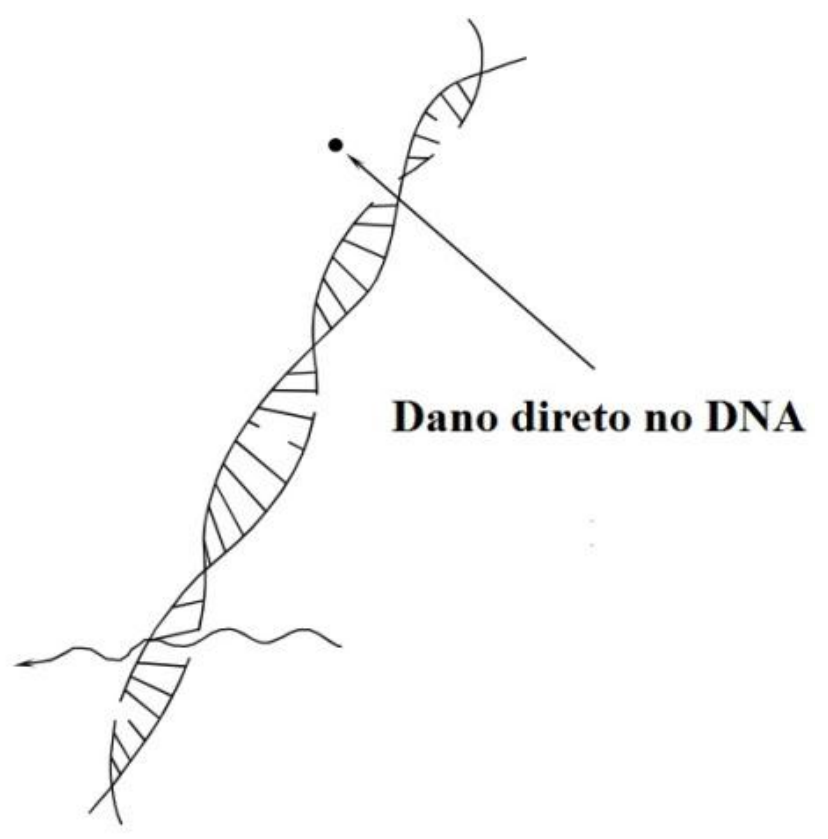

Fonte: (NRC, 2012).

A radiação ionizante pode reagir com a água, que forma a maior parte do volume da célula, e produzir radicais livres que podem se recombinar ou reagir com outros fragmentos, 
como o DNA, danificando o mesmo e contribuindo para a destruição celular. Tal efeito, considerado indireto, é muito importante para células vegetativas, cujo o citoplasma apresenta cerca de 80\% de água (DIEHL, 1995; NRC, 2012).

Figura 4 - Exemplo do efeito indireto da radiação.

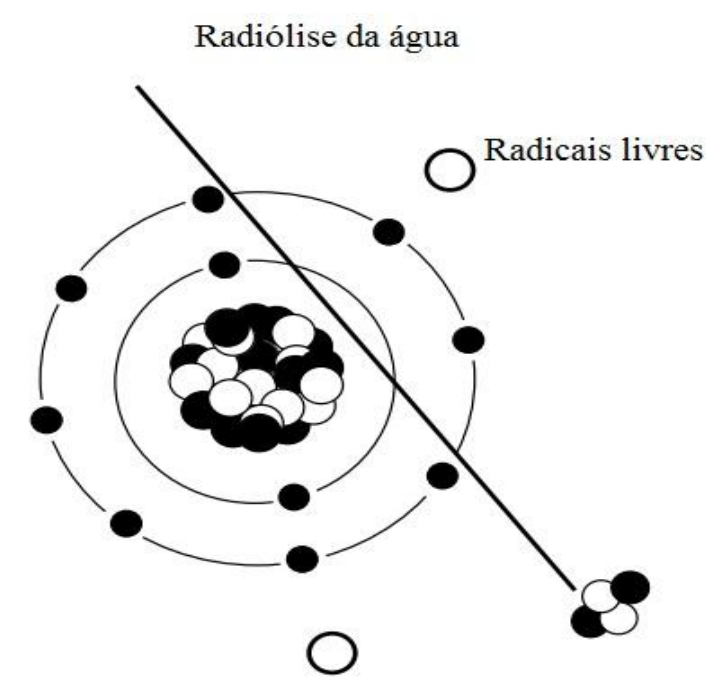

Fonte: (NRC, 2012).

\subsubsection{Efeitos biológicos da radiação}

A radiação ionizante quando aplicada em materiais biológicos causa efeitos diretos nas células, como por exemplo danos ao ácido nucléico e de forma alternativa os efeitos indiretos, produzindo radicais livres que podem interagir com o pontos críticos do microrganismo causando a destruição do mesmo, células em divisão, ou as que estão metabolicamente ativas, ou ainda as que se reproduzem rapidamente, são mais sensíveis que aquelas altamente diferenciadas, a destruição ou inativação do microrganismo pela irradiação ocorre em progressão geométrica (DIEHL, 1995; HANSEN; SHAFFER, 2001; OKUNO, 1988).

As doses de radiação causa pequenas mudanças químicas em alimentos, mas causa mudanças letais em uma célula bacteriana, as moléculas de DNA são enormes comparadas com outras moléculas dentro da estrutura celular, por isso constituem o alvo principal dos efeitos da radiação (AQUINO, 2003; DIEHL, 1995).

A sensibilidade à radiação de macromoléculas é aproximadamente proporcional ao seu peso molecular, estima-se que uma dose de $0,1 \mathrm{kGy}$ danifica 2,8 \% do DNA numa célula bacteriana, enquanto que a mesma dose danificaria $0,14 \%$ das enzimas e apenas $0,005 \%$ dos 
aminoácidos, isso explica porque uma dada dose de radiação pode ter efeito letal em microrganismos de um alimento irradiado, sem causar grandes alterações na composição química do alimento (POLLARD, 1966).

O efeito da radiação em microrganismos já foi descrito por vários autores, como o trabalho de Onyenekwe, Ogbadu e Hashimoto (1997), que isolou fungos do gênero Fusarium spp. e Aspergillus spp. de uma espécie de pimenta (Piper guineese), e concluiu que doses de 10 kGy foram necessárias para descontaminação total do condimento sem alterar seus valores nutricionais.

A idade da cultura pode influenciar na sensibilidade à irradiação, Segundo Diehl (1995), culturas com 3 semanas de A. flavus requerem uma dose de 2 kGy para prevenir o crescimento do fungo, enquanto que doses de $1 \mathrm{kGy}$ são suficientes para inibir o crescimento da mesma cultura com 6 semanas. Fungos que apresentam maior conteúdo lipídico são mais resistentes aos efeitos da radiação quando comparados a outros de menor concentração lipídica (AZIZ et al., 1997), estudos verificando a radiorresistência de fungos dos gêneros Aspergillus, Cladosporium, Curvularia, Penicillium, Fusarium e Alternaria verificou-se que as espécies Alternaria alternata, Cladosporium cladosporioides, Curvularia lunata e Curvularia geniculata, foram mais resistentes aos efeitos da radiação gama (SALEH et al., 1988).

Ferreira-Castro et al. (2007), empregaram doses de $20 \mathrm{kGy}$ em amostras de milho contaminadas com Aspergillus flavus e Fusarium verticillioides eliminando, assim, os possíveis agentes contaminantes.

\subsubsection{Efeitos da radiação ionizante em alimentos}

A ingestão de alimentos contaminados afeta grande parte da população mundial, até mesmo os países desenvolvidos, a radiação ionizante em alimentos vem sendo amplamente utilizada para vários objetivos, como desinfestação do alimento, prolongando o tempo de conservação, inibição de brotamento, controle de pragas. O processamento de alimentos por radiação requer uma exposição cuidadosa e controlada frente à dose de energia conhecida, a dose administrada tem que atingir o resultado desejado, evitando, ao mesmo tempo, a degradação do alimento (AQUINO, 2003; IAEA, 1999).

$\mathrm{O}$ tipo de radiação utilizado no tratamento de alimentos se limita às radiações ionizantes provenientes do raio-X (máquinas de energia $5 \mathrm{MeV}$ ), raios gama de alta energia ( 
fonte cobalto-60 ou césio-137) e feixe de elétrons (aceleradores de elétrons), o radionucleotídeo utilizado quase que exclusivamente para irradiação de alimentos, com raios gama, é o cobalto-60, pois não há fornecimento de césio-137 em quantidades comerciais (IAEA, 2012; WHO, 1994).

O feixe de elétron é bastante utilizado em embalagens finas de alimentos ou em grãos de fluxo livre ou em quedas, sendo a radiação gama fonte $\mathrm{Co}^{60}$ amplamente utilizada irradiação de alimentos (IAEA, 1999).

A irradiação destrói microrganismos causadores de doenças, inclusive os vermes parasitas e insetos que deterioram os alimentos armazenados, em nenhum momento, durante o processo de irradiação, o alimento entra em contato com a fonte de radiação (MATSUDA, 2002; OMS, 1989).

Os organismos mais simples são mais resistentes aos efeitos da radiação ionizante, os vírus, por exemplo, são mais resistentes do que as bactérias, as quais são mais resistentes que os bolores, sendo os bolores mais resistentes que os seres humanos (MONK, 1995).

Segundo IAEA (1999), Murano (1995) e Villavincencio (1998), o uso da irradiação por si só como uma técnica de preservação, não vai resolver todos os problemas das perdas nos alimentos pós-colheita, porém, representa um papel importante na redução de perdas. $\mathrm{O}$ uso da irradiação ajuda também a diminuir a dependência da utilização de agentes químicos no controle de pragas em alimentos, a eficácia da ação da irradiação de alimentos vai depender dos seguintes fatores:

- a dose a ser empregada;

- número de microrganismos presentes (inicialmente) no alimento;

- tipo e espécie de microrganismo;

- estado físico ou químico do alimento (pH, presença de oxigênio, umidade, temperatura);

- composição do alimento;

- idade dos microrganismos, células vegetativas ou esporuladas podem influenciar na sensibilidade do microrganismo.

A international health e autoridades de segurança dos alimentos, estabeleceram uma dose para a irradiação de alimentos de até $10 \mathrm{kGy}$, porém em uma avaliação recente de um grupo internacional de pesquisa organizado pela FAO, IAEA e WHO, demonstrou que 
alimentos tratados com boas práticas de fabricação em qualquer dose acima de $10 \mathrm{kGy}$ também são seguros para o consumo (IAEA, 1999).

A aplicação da radiação deve ser feita em alimentos embalados, mas não evita a recontaminação ou a reinfestação, a irradiação não substitui a manipulação adequada dos produtos, pois não é capaz de melhorar a qualidade de um produto cuja a qualidade inicialmente seja duvidosa; o procedimento não devolve a propriedade sensorial normal do alimento, ou seja, não elimina odores ou sabores desagradáveis ou aspecto de um alimento já decomposto, o alimento a ser irradiado deve seguir as boas praticas de fabricação, pois o sucesso do processo é em função da qualidade do produto original (FARKAS, 1985; MATSUDA, 2002; VILLAVICENCIO, 1998).

As perdas de nutrientes dos alimentos irradiados são pequenas ou nulas e muitas vezes significativamente menor do que as perdas associadas a outros métodos de conservação como, enlatar, secar, pasteurizar, isso acontece principalmente quando é respeitada a dose certa para cada tipo de alimento (DIEHL, 1994; IAEA, 1999).

A radiação ionizante pode causar oxidação de lipídios, por isso deve-se ter cuidado com a dose administrada, principalmente em alimentos com alto teor de gordura, pois altas doses podem causar rancidez em alguns produtos (SILVA, 2008).

\subsubsection{Legislação para irradiação de alimentos}

Em 1984 a Organização Mundial da Saúde (OMS) em conjunto com a Organização das Nações Unidas para a Alimentação e Agricultura (FAO) e a Agência Internacional de Energia Atômica (IAEA), criaram o ICGFI (International Consultative Group on Food Irradiation) para estudar as diversas aplicações da irradiação de alimentos, o Brasil e mais 44 países fazem parte desse grupo. Somente os países Brasil, Chile e Argentina têm legislações sobre irradiação de alimentos, estas legislação diferem entre si principalmente em termos de alimentos que podem ser irradiados e doses aplicadas (AQUINO, 2003; MATSUDA, 2002).

Os fabricantes devem adicionar informações explicando o porquê da utilização da irradiação, e o símbolo na embalagem do alimento tratado pelo processo de irradiação. $\mathrm{O}$ símbolo internacional para a irradiação de alimentos é conhecido como radura (Anexo, figura 3.A) (pétalas verdes soltas dentro de um círculo quebrado), esse símbolo deve ser acompanhado pelas palavras "tratado por irradiação" ou "tratado com irradiação" (FERREIRA, 2005). 
No Brasil, as Portarias no 09/1985 e n 30/1989 do DINAL/MS, ambas revogadas a partir da Resolução da Diretoria colegiada, RDC n 21 de 26 de janeiro de 2001 da ANVISA, dispõe sobre o regulamento técnico para a irradiação de alimentos.

\subsection{Prevenção e controle de micotoxinas}

Os grãos e em geral e outros alimentos podem sofrer alterações em sua qualidade ainda no campo, durante a maturação, até o momento do seu consumo, essas alterações são causadas por fungos, insetos, manuseio durante a colheita, recebimento, secagem e armazenamento, há portanto a necessidade de um sistema de educação e treinamento para o agricultor, o processador, revendedor e consumidor de produtos capazes de portar fungos, já que no Brasil a "legislação rigorosa" de alimentos é praticamente inexistente (LAZZARI, 2000; SABINO, 2000).

A contaminação dos alimentos durante a colheita pode ser reduzida através da implantação de práticas agrícolas adequadas que limitem o desenvolvimento fúngico. Após a colheita a contaminação pode ser minimizada através de métodos adequados de secagem e armazenamento, assim como o monitoramento micológico e micotoxicológico regular (CONKOVÁ et al., 2003; RUSTOM, 1997).

Até o momento não existe uma metodologia adequada que permite a aplicação de práticas, a nível industrial, para controle das diferentes micotoxinas, e muitos procedimentos aplicados causam perdas na qualidade dos alimentos e consequentemente perdas econômicas, como por exemplo, processos químicos, biológicos e físicos (HUWIG, 2001; ILENDER, 1999).

- Processos Químicos: algumas micotoxinas podem ser destruídas por hidróxido de cálcio, ozônio ou amônia. A amonização, por exemplo, é um procedimento liberado em diversos países para a descontaminação de aflatoxinas, porém apresenta ineficiência na redução de outras micotoxinas e também pode causar problemas à saúde devido ao excesso de resíduos de amônia no alimento, as aflatoxinas são também destruídas por tratamento com hipoclorito (SEKIYAMA et al., 2007; WHO, 1979).

- Processos biológicos: Estes estão em estudos e ainda não são utilizados na prática de descontaminação de micotoxinas, na prática é a utilização de microrganismos que metabolizam as toxinas, como a conversão de aflatoxina $\mathrm{B}_{1}\left(\mathrm{AFB}_{1}\right)$ pelo 
Flavobacterium auranticum em produtos menos tóxicos, ou a degradação da $\mathrm{AFB}_{1}$ por Aspergillus niger (KRISHNAMURTHY et al., 2006; SEKIYAMA et al., 2007).

- Processos físicos: Geralmente as micotoxinas são compostos termoestáveis, a aplicação dos tratamentos físicos depende do grau de contaminação das toxinas no alimento, as aflatoxinas puras no estado livre em água são muito estáveis ao calor (BINDER, 2000; ILENDER, 1999). Segundo Van Der Zijden et al., (1962) as aflatoxinas são decompostas à temperatura de cerca de $220^{\circ} \mathrm{C}$, não sendo favorável a aplicação em alimentos. A adsorção é também utilizada para o controle de micotoxinas, onde os adsorventes, por exemplo, são misturados às rações e se unem a micotoxina no trato gastrointestinal diminuindo a disponibilidade da micotoxina e associações tóxicas (SEKIYAMA, 2007).

Segundo Rustom (1997), a radiação ionizante vem sendo aplicada para obtenção de alimentos livres de microrganismos patogênicos, favorecendo a preservação do produto.

Visconti et al. (1996), aplicaram doses de radiação de $15 \mathrm{kGy}$ em farinha de milho naturalmente contaminada, essa dose foi suficiente para eliminar o crescimento de microrganismos e redução nas concentrações de fumonisinas na ordem de $20 \%$.

O estudo de Ferreira (2005), demonstrou que a administração de doses de radiação superiores a 5 kGy em milho contaminado com Fusarium verticillioides foi eficaz na inibição do crescimento do fungo, e que o uso de doses de $10 \mathrm{kGy}$ reduziu a concentração de fumonisinas em $50 \%$.

Aquino (2003), demonstrou que doses de irradiação de 2, 5 e 10 kGy foram eficientes para na redução de Aspergillus flavus em grãos de milho, porém, as doses de 5 e 10 kGy foram mais efetivas, e a dose de $10 \mathrm{kGy}$ degradou totalmente as aflatoxinas.

Rogovschi et al. (2009), estudou a aplicação de feixe de elétrons nas doses de 5 kGy em ágar coco com Aspergillus flavus, e observou que o tratamento destruiu $75,49 \%$ da aflatoxina $\mathrm{B}_{1}$.

A radiação ionizante age no anel furano terminal das aflatoxinas, originando produtos de baixa atividade biológica (RUSTOM, 1997).

A melhor forma de evitar a contaminação por micotoxinas é prevenindo sua formação, medidas preventivas de pragas são importantes na conservação dos alimentos, porém raramente são realizadas pelos responsáveis do armazenamento (LORINI, 2000; SEKIYAMA, 2007). 


\section{PROPOSIÇÕES E OBJETIVOS}

A produção de castanha-do-Brasil sofreu uma queda desde 1990 quando o país produzia pouco mais de 50 mil toneladas/ano. Na última avaliação, a produção brasileira tem mantido desde 2000, cerca de 30 mil toneladas/ano.

A cada ano que se passa surgem novas tecnologias para controle de fungos e micotoxinas em castanha-do-Brasil, como os descritos por Scussel et al., 2011, que propuseram a aplicação de métodos com atmosfera modificada (ozônio, dióxido de carbono e absorventes), em castanhas previamente embaladas, dos tratamentos testados o único que promoveu a degradação de aflatoxinas além da inibição do crescimento de microrganismos foi a aplicação de ozônio.

A legislação Brasileira permite o uso de fontes do radioisótopo cobalto-60 e aceleradores de elétrons para irradiar alimentos.

Tendo em vista o elevado índice de contaminação por aflatoxinas em lotes de castanha-do-Brasil e o rigoroso controle dos países importadores em relação aos níveis de toxinas presentes nos alimentos, os países da União Europeia decidiram, em 2003, pela devolução de lotes deste produto oriundos do Brasil. A partir de então, passaram a exigir condições especiais para a importação do produto, tais como o atendimento às Boas Práticas Extrativistas, com respectiva comprovação pelas autoridades brasileiras e determinação dos teores de aflatoxinas por laboratórios credenciados junto ao Ministério da Agricultura, Pecuária e Abastecimento.

No Brasil, as exigências quanto ao controle de aflatoxinas na castanha-do-Brasil são menos restritivas assim sendo, os lotes rejeitados por países europeus podem ser direcionados ao mercado nacional, fato que representa grande risco para a saúde da população. Desta forma, o controle da contaminação fungica e de aflatoxinas é de extrema relevância não apenas porque evita grandes perdas econômicas e impacto socioambiental na região, mas principalmente por se constituir uma questão de saúde pública.

O emprego do tratamento pelo processo de irradiação pode ser um valioso meio de prevenir os riscos de contaminação fungica, além de representar a alternativa mais viável para a descontaminação desta classe de produto. Os estudos sobre castanha-do-Brasil são escassos e não há relatos sobre o controle de fungos utilizando métodos de irradiação, sobretudo o feixe de elétrons. 
Com base nessas informações o presente trabalho teve como objetivo geral avaliar os efeitos da radiação gama e da aplicação de feixe de elétrons sobre castanhas-do-Brasil artificialmente inoculadas com Aspergillus flavus.

Os objetivos específicos foram:

- avaliar os efeitos de diferentes doses de radiação gama e de feixes de elétrons em amostras de castanha-do-Brasil artificialmente inoculadas com Aspergillus flavus;

- avaliar os efeitos da radiação gama e feixe de elétrons na aflatoxina;

- realizar análise sensorial de amostras de castanha-do-Brasil tratadas pelos dois processos de irradiação;

- comparar os resultados obtidos pelos dois métodos de irradiação. 


\section{MATERIAIS E MÉTODOS}

\subsection{Amostras}

Foram utilizadas 50 amostras de castanha-do-Brasil, adquiridas no comércio varejista da Cidade de São Paulo, contendo 250 g cada. As amostras foram esterilizadas e inoculadas com cepa padrão de A. flavus toxigênica. Antes da irradiação foi realizada pesquisa da micobiota, a determinação da atividade de água, e a determinação de aflatoxinas, para se obter a concentração de aflatoxinas antes da irradiação. Em seguida, cada amostra foi subdividida em 5 grupos (subamostras), contendo $50 \mathrm{~g}$ cada, as quais receberam as seguintes denominações e doses de radiação: controle (0 kGy), 5 e 10 kGy F.E, 5 e 10 kGy R.G. Após a irradiação, foram realizadas 250 análises de atividade de água, 250 análises de micobiota e 250 análises de aflatoxinas. A micobiota foi realizada em triplicata e a pesquisa de aflatoxinas, em duplicata.

Análise sensorial foi realizada em um lote de $1250 \mathrm{~g}$ de amostra de castanha-do-Brasil que foi previamente subdividida em 5 grupos, embalada e irradiada com radiação gama e feixe de elétrons nas doses 0 (controle), 5 e $10 \mathrm{kGy}$.

\subsection{Determinação de atividade de água}

A atividade de água das amostras de castanha-do-Brasil (amêndoa) foi determinada utilizando o aparelho AQUALAB CX-2 (Decagon Devices Inc). (Apêndice A, figura 3.AP).

\subsection{Cepa de $A$. flavus}

As amostras foram inoculadas com cepa de A. flavus produtora de aflatoxinas do grupo B (IMI 190), proveniente do Internation Mycology Institute, Londres, Inglaterra.

A suspensão foi preparada em frascos contendo solução tampão fosfato-salino (PBS) com pH corrigido para 7,2 e adicionado de $0,1 \mathrm{~mL}$ de tween 80 . A contagem foi efetuada usando câmara de Neubauer e o número de esporos foi ajustado para $1 \times 10^{5}$ esporos $/ \mathrm{mL}$ (AQUINO et al., 2003).Volume de $1 \mathrm{ml}$ da suspensão foi adicionado a cada amostra de $250 \mathrm{~g}$ de castanha previamente esterilizada por óxido de etileno. 


\subsection{Condições de incubação das amostras inoculadas com A. flavus}

Após inoculação com A. flavus, as amostras foram mantidas durante até 15 dias em estufa BOD ajustada a $30{ }^{\circ} \mathrm{C}$, no escuro, sob umidade relativa de 93,0\% obtida utilizando solução salina saturada de sulfato de potássio $\left(\mathrm{K}_{2} \mathrm{SO}_{4}\right)$ a $10 \%$ de acordo com Winston e Bates 1960.

\subsection{Micobiota}

A pesquisa da micobiota foi realizada empregando-se a técnica da diluição seriada com semeadura em superfície (PITT; HOCKING, 2009). Foram utilizadas dez gramas de cada amostra, previamente trituradas e homogeneizadas, diluídas em $90 \mathrm{~mL}$ de água destilada estéril (diluição $10^{-1}$ ). A partir desta, foram realizadas diluições decimais sucessivas até $10^{-3}$, e inoculado 0,1 $\mathrm{mL}$ de cada amostra em placas de Petri contendo o meio de ágar batata dextrose. As placas foram incubadas em condições controladas de umidade relativa (93\%) e de temperatura $\left(25^{\circ} \mathrm{C}\right)$ por até 10 dias. Após esse período foi realizada a contagem de colônias e a correção pelo fator de diluição, a fim de obter o número de unidades formadoras de colônia por grama (UFC/g) de substrato (BUSTA et al., 1984). As análises foram realizadas em triplicata.

\subsection{Esterilização das amostras}

As amostras utilizadas foram previamente esterilizadas com óxido de etileno pela empresa ACECIL, Campinas, São Paulo, porém, aquelas empregadas nas análises sensoriais não foram esterilizadas.

\subsection{Tratamento pelo processo de irradiação}

Após 15 dias da incubação, as amostras inoculadas foram subdivididas em 5 grupos e acondicionadas em sacos de polietileno individuais seladas a vácuo (Apêndice A, figura 5.AP) e, posteriormente tratadas pelos processos de radiação ionizante, tanto por feixe de elétrons como por radiação gama, com doses de 0,5 e $10 \mathrm{kGy}$. O processo de irradiação foi conduzido no Instituto de Pesquisas Energéticas e Nucleares (IPEN - USP), utilizando para 
tratamento com radiação gama, Fonte Gammacell ${ }^{60} \mathrm{Co}$ e para tratamento por feixe de elétrons, Acelerador de elétrons.

\subsection{Análise sensorial}

Os testes de análise sensorial foram feitos conforme as normas preconizadas pelo IAL (2008), utilizando 30 provadores que fizeram o teste de aceitação por escala hedônica de 9 pontos com os extremos 1 (desgostei extremamente) e 9 (gostei extremamente). Após avaliação do sabor, odor e textura das amostras irradiadas, os dados obtidos foram avaliados estatisticamente pela análise de variância ANOVA com médias comparadas pelo teste Tukey $(\mathrm{p}<0,05)$.

\subsection{Determinação de aflatoxinas}

Todos os solventes utilizados nas etapas de determinação de aflatoxinas das amêndoas foram grau CLAE (Merck, Darmstadt, Alemanha). Foi utilizada água Milli-Q obtida no equipamento Academic System (Millipore, Marlborough, MA, EUA).

Os padrões de aflatoxinas $B_{1}, B_{2}, G_{1}$ e $G_{2}$ (Sigma, St. Louis, MO, EUA), antes de serem utilizados, foram ressuspendidos em solução de benzeno:acetonitrila (98:2, v:v) e quantificados em espectrofotômetro DU 640 (Beckman, EUA). A partir da concentração encontrada, foi realizada diluição a $1 \mu \mathrm{g} / \mathrm{mL}$ de cada aflatoxina. A partir dessa solução foram realizadas as diluições para uso nas atividades propostas.

\subsubsection{Extração de aflatoxinas}

A técnica para determinação de aflatoxinas foi baseada em Baquião, et al. (2012).

Foi utilizada $50 \mathrm{~g}$ cada amostra, foram previamente trituradas e homogeneizadas. Em seguida, alíquota de $2,5 \mathrm{~g}$ foi utilizada para a pesquisa de aflatoxinas.

Estas 2,5 g foram transferidas para um tubo de polipropileno (tipo Falcon) de $50 \mathrm{~mL}$, adicionou-se $12,5 \mathrm{~mL}$ de solução acetonitrila:água $(85: 15$, v/v). Os tubos foram submetidos agitação em vórtex por 1 minuto e, posteriormente, a agitador mecânico horizontal a $180 \mathrm{rpm}$ durante 60 minutos. Em seguida, os tubos foram centrifugados a $10000 \mathrm{rpm}$ durante 3 minutos. Cinco mililitros do sobrenadante foram, então, transferidos para outro tubo de 
polipropileno de $50 \mathrm{~mL}$ e adicionado $45 \mathrm{ml}$ de água acidificada $0,5 \%$. O tubo foi, então, agitado vigorosamente. A partir desta solução foi realizada a extração em fase sólida, utilizando cartucho Strata C18-E $500 \mathrm{mg} / 3 \mathrm{~mL}$, previamente condicionado com $3 \mathrm{~mL}$ de metanol e $6 \mathrm{~mL}$ de água acidificada 0,5\%. A solução foi submetida a fluxo de 1 gota/segundo, com auxílio de bomba a vácuo. Após esta etapa, a limpeza foi realizada pela adição de $12 \mathrm{~mL}$ de água acidificada $0,5 \%$ e a eluição das aflatoxinas foi feita com $1 \mathrm{~mL}$ de metanol em frasco âmbar. $\mathrm{O}$ metanol foi evaporado a resíduo e os frascos foram armazenados a $-4{ }^{\circ} \mathrm{C}$ até $\mathrm{o}$ momento da derivatização química.

\subsubsection{Derivatização química das aflatoxinas}

A derivatização química dos extratos foi realizada com a finalidade de aumentar os sinais cromatográficos das $\mathrm{AFB}_{1}$ e $\mathrm{AFG}_{1}$, transformando-as em $\mathrm{AFB}_{2 \mathrm{a}}$ e $\mathrm{AFG}_{2 \mathrm{a}}$, respectivamente, confirmando a identidade química desses compostos. Assim, o procedimento foi realizado pela adição de $200 \mu \mathrm{L}$ de hexano e $100 \mu \mathrm{L}$ de ácido trifluoracético (TFA) (Sigma-Aldrich, St. Louis, MO, USA), os frascos foram incubados em banho seco a 40 ${ }^{\circ} \mathrm{C}$ por 15 minutos e, a seguir, a solução derivatizante foi evaporada sob nitrogênio e, os frascos, armazenados a $-4{ }^{\circ} \mathrm{C}$ até a separação cromatográfica.

\subsubsection{Cromatografia Líquida de Alta Eficiência (CLAE) para separação de aflatoxinas}

As amostras foram ressuspendidas em $500 \mu \mathrm{L}$ de solução metanol: água (1:1, v/v) e 10 $\mu \mathrm{L}$ de cada amostra foram injetados em cromatógrafo Shimadzu modelo Proeminence acoplado ao Software LC Solution (Shimadzu Corporation, Kyoto, Japão) através de injetor automático. As aflatoxinas, quando presentes, foram separadas por CLAE, tendo como fase móvel isocrática composta por água:acetonitrila:metanol (8:1,5:1,5 v/v/v) 0,1\% TFA a um fluxo de $1 \mathrm{~mL} / \mathrm{min}$. A fase móvel foi baseada em trabalho de Scott et al. (1990). Foram utilizados detector de fluorescência RF-10AX (365 nm de excitação e $450 \mathrm{~nm}$ de emissão), coluna Shim-Pack VP-ODS 150L X 4,6 (Shimadzu) (Apêndice, figura 4.AP) e cartucho de pré-coluna Shim-Pack GVP-ODS 10 X 4,6 (Shimadzu) em forno com temperatura controlada a $40{ }^{\circ} \mathrm{C}$. As aflatoxinas, segundo essa metodologia, tiveram aproximadamente os seguintes tempos de retenção de 5,0;6,8;10,0;14,6 minutos para $\mathrm{AFG}_{1}, \mathrm{AFB}_{1}, \mathrm{AFG}_{2}$ e $\mathrm{AFB}_{2}$, respectivamente. $\mathrm{O}$ tempo total de cromatografia foi de 20 minutos para cada amostra. 


\subsubsection{Análise estatística}

Todos os dados foram submetidos ao teste de Tukey $(\mathrm{p}<0,05)$ de comparações múltiplas, usando o software Graphpad prism 5, com análise de dados e métodos ajustados realizados no Centro de Estatística Aplicada do Instituto de Matemática e Estatística (IME) da USP. 


\section{RESULTADOS E DISCUSSÃO}

\subsection{Atividade de água}

As 50 amostras de castanha-do-Brasil analisadas, denominadas A1 a A50, apresentaram níveis de atividade de água variando de 0,44 a 0,59 com média de 0,48 (antes da incubação) e de 0,78 a 0,88, média de 0,80 (após incubação). (Quadro2). A temperatura média das amostras após a incubação foi de $29,7^{\circ} \mathrm{C}$. Segundo Lacey et al. (1991), que consideram a água o mais importante fator para o crescimento fúngico, as faixas de temperatura e de atividade de água (Aa) necessárias para o crescimento de A. flavus são de 6 a $45^{\circ} \mathrm{C}$ e de 0,78 a 0,80 , respectivamente, sendo a temperatura e a atividade de água ótimas de 35 a $37{ }^{\circ} \mathrm{C}$ e atividade de água de 0,95. Para a produção de aflatoxinas, a Aa mínima varia de 0,83 a 0,87.

Em nosso experimento constatamos que em algumas amostras até com 0,78 houve a produção de aflatoxina $\mathrm{B}_{1}$. Geograficamente, dentro do gênero Aspergillus, as espécies $A$. flavus e A. parasiticus são frequentemente isoladas em regiões tropicais e subtropicais, pouco freqüentes em regiões de clima temperado e raramente isolados em regiões de clima frio.

Quadro 2 - Níveis de Aa das amostras de castanha-do-Brasil, antes e após incubação por 15 dias.

\begin{tabular}{|c|c|c|}
\hline \multirow{2}{*}{ Amostra } & \multicolumn{2}{|c|}{ Atividade de água } \\
\cline { 2 - 3 } & Antes da incubação & Após incubação \\
\hline Amostra 01 & 0,55 & 0,83 \\
\hline Amostra 02 & 0,54 & 0,81 \\
\hline Amostra 03 & 0,58 & 0,84 \\
\hline Amostra 04 & 0,57 & 0,88 \\
\hline Amostra 05 & 0,57 & 0,81 \\
\hline Amostra 06 & 0,57 & 0,82 \\
\hline Amostra 07 & 0,55 & 0,83 \\
\hline Amostra 08 & 0,59 & 0,84 \\
\hline Amostra 09 & 0,56 & 0,83 \\
\hline Amostra 10 & 0,57 & 0,82 \\
\hline Amostra 11 & 0,49 & 0,79 \\
\hline Amostra 12 & 0,47 & 0,78 \\
\hline Amostra 13 & 0,48 & 0,81 \\
\hline Amostra 14 & 0,47 & 0,80 \\
\hline
\end{tabular}




\begin{tabular}{|c|c|c|}
\hline Amostra 15 & 0,49 & 0,79 \\
\hline Amostra 16 & 0,47 & 0,78 \\
\hline Amostra 17 & 0,48 & 0,79 \\
\hline Amostra 18 & 0,47 & 0,79 \\
\hline Amostra 19 & 0,48 & 0,80 \\
\hline Amostra 20 & 0,47 & 0,80 \\
\hline Amostra 21 & 0,49 & 0,78 \\
\hline Amostra 22 & 0,47 & 0,79 \\
\hline Amostra 23 & 0,48 & $\overline{0,81}$ \\
\hline Amostra 24 & 0,45 & 0,78 \\
\hline Amostra 25 & 0,49 & 0,78 \\
\hline Amostra 26 & 0,50 & 0,80 \\
\hline Amostra 27 & 0,46 & 0,82 \\
\hline Amostra 28 & 0,47 & 0,82 \\
\hline Amostra 29 & 0,47 & 0,82 \\
\hline Amostra 30 & 0,49 & 0,78 \\
\hline Amostra 31 & 0,46 & 0,83 \\
\hline Amostra 32 & 0,44 & 0,84 \\
\hline Amostra 33 & 0,44 & 0,79 \\
\hline Amostra 34 & 0,45 & 0,79 \\
\hline Amostra 35 & 0,46 & 0,83 \\
\hline Amostra 36 & 0,43 & 0,83 \\
\hline Amostra 37 & 0,44 & 0,81 \\
\hline Amostra 38 & 0,45 & 0,79 \\
\hline Amostra 39 & 0,45 & 0,80 \\
\hline Amostra 40 & 0,46 & 0,79 \\
\hline Amostra 41 & 0,46 & 0,80 \\
\hline Amostra 42 & 0,45 & 0,79 \\
\hline Amostra 43 & 0,44 & 0,78 \\
\hline Amostra 44 & 0,47 & 0,79 \\
\hline Amostra 45 & 0,48 & 0,79 \\
\hline Amostra 46 & 0,48 & 0,80 \\
\hline Amostra 47 & 0,45 & 0,79 \\
\hline Amostra 48 & 0,47 & 0,78 \\
\hline Amostra 49 & 0,49 & 0,79 \\
\hline Amostra 50 & 0,50 & 0,78 \\
\hline
\end{tabular}




\subsection{Pesquisa da micobiota}

A pesquisa da micobiota das 50 amostras, antes de serem subdivididas (inoculadas artificialmente e analisadas após incubação) (Apêndice, figura 6.AP) revelou número de UFC/g de A. flavus variando de $1 \times 10^{1}$ a $4 \times 10^{4}$.

Após os tratamentos com radiação ionizante, observamos que, as amêndoas submetidas ao tratamento com Feixe de Elétrons utilizando dose de 5 kGy resultou na ausência de crescimento de A. flavus em 74 \% (37/50) das amostras (Apêndice A, figura 7.AP), enquanto que as amostras tratadas com $10 \mathrm{kGy,} 94 \%$ (47/50) não tiveram crescimento do fungo (Apêndice, figura 8.AP). As amostras tratadas com Radiação Gama, na dose de 5 kGy, 92 \% (46/50) não revelaram crescimento fúngico (Apêndice, figura 9.AP), porém, todas as amostras tratadas com 10 kGy não apresentaram crescimento fúngico (50/50) (Apêndice, figura 10.AP). Desta forma, observamos que ambos os processos de irradiação apresentaram redução da micobiota, porém, a Radiação Gama mostrou maior eficiência (Quadro 3). A sensibilidade de fungos à radiação ionizante foi discutida previamente por diversos autores, que citaram valores de doses compreendidas entre 4 a 10 kGy para a inibição da contaminação fúngica natural em alimentos e especiarias (AQUINO et al., 2005; AZIZ et al., 1997).

Quadro 3 - Número de UFC/g de A. flavus após período de incubação de 15 dias em amostras artificialmente inoculadas: controle e após os tratamentos por radiação ionizante.

\begin{tabular}{|c|c|c|c|c|c|}
\hline \multirow{2}{*}{ Amostra } & \multicolumn{5}{|c|}{ Subdivisões/subamostras } \\
\cline { 2 - 6 } & Controle & $\begin{array}{c}\text { Após irradiação } \\
\text { com FE-5kGy }\end{array}$ & $\begin{array}{c}\text { Após irradiação } \\
\text { com FE-10kGy }\end{array}$ & $\begin{array}{c}\text { Após irradiação } \\
\text { com RG - 5kGy }\end{array}$ & $\begin{array}{c}\text { Após irradiação } \\
\text { com RG- 10kGy }\end{array}$ \\
\hline Amostra 01 & $2 \times 10^{2}$ & 0 & 0 & 0 & 0 \\
\hline Amostra 02 & $2 \times 10^{2}$ & 0 & 0 & 0 & 0 \\
\hline Amostra 03 & $1 \times 10^{2}$ & $1 \times 10^{1}$ & 0 & 0 & 0 \\
\hline Amostra 04 & $3 \times 10^{2}$ & $1 \times 10^{2}$ & 0 & 0 & 0 \\
\hline Amostra 05 & $3 \times 10^{2}$ & 0 & 0 & $1 \times 10^{1}$ & 0 \\
\hline Amostra 06 & $2 \times 10^{2}$ & 0 & 0 & 0 & 0 \\
\hline Amostra 07 & $1 \times 10^{2}$ & $1 \times 10^{1}$ & 0 & $1 \times 10^{1}$ & 0 \\
\hline Amostra 08 & $2 \times 10^{4}$ & $1 \times 10^{2}$ & $1 \times 10^{1}$ & 0 & 0 \\
\hline Amostra 09 & $2 \times 10^{4}$ & 0 & 0 & 0 & 0 \\
\hline
\end{tabular}




\begin{tabular}{|c|c|c|c|c|c|}
\hline Amostra 10 & $1 \times 10^{3}$ & 0 & 0 & 0 & 0 \\
\hline Amostra 11 & $2 \times 10^{2}$ & 0 & 0 & 0 & 0 \\
\hline Amostra 12 & $3 \times 10^{2}$ & 0 & 0 & 0 & 0 \\
\hline Amostra 13 & $1 \times 10^{1}$ & 0 & 0 & 0 & 0 \\
\hline Amostra 14 & $2 \times 10^{1}$ & 0 & 0 & 0 & 0 \\
\hline Amostra 15 & $3 \times 10^{2}$ & 0 & 0 & 0 & 0 \\
\hline Amostra 16 & $1 \times 10^{2}$ & 0 & 0 & 0 & 0 \\
\hline Amostra 17 & $3 \times 10^{1}$ & 0 & 0 & 0 & 0 \\
\hline Amostra 18 & $2 \times 10^{2}$ & 0 & 0 & 0 & 0 \\
\hline Amostra 19 & $2 \times 10^{2}$ & 0 & 0 & 0 & 0 \\
\hline Amostra 20 & $2 \times 10^{1}$ & 0 & 0 & 0 & 0 \\
\hline Amostra 21 & $2 \times 10^{3}$ & 0 & 0 & 0 & 0 \\
\hline Amostra 22 & $3 \times 10^{3}$ & $1 \times 10^{2}$ & 0 & 0 & 0 \\
\hline Amostra 23 & $4 \times 10^{4}$ & 0 & 0 & 0 & 0 \\
\hline Amostra 24 & $2 \times 10^{3}$ & $1 \times 10^{2}$ & 0 & 0 & 0 \\
\hline Amostra 25 & $2 \times 10^{3}$ & 0 & 0 & 0 & 0 \\
\hline Amostra 26 & $4 \times 10^{3}$ & 0 & 0 & 0 & 0 \\
\hline Amostra 27 & $3 \times 10^{4}$ & $1 \times 10^{1}$ & 0 & 0 & 0 \\
\hline Amostra 28 & $1 \times 10^{4}$ & 0 & 0 & 0 & 0 \\
\hline Amostra 29 & $4 \times 10^{3}$ & 0 & 0 & 0 & 0 \\
\hline Amostra 30 & $5 \times 10^{3}$ & $1 \times 10^{2}$ & $1 \times 10^{1}$ & $1 \times 10^{1}$ & 0 \\
\hline Amostra 31 & $5 \times 10^{2}$ & $1 \times 10^{1}$ & 0 & 0 & 0 \\
\hline Amostra 32 & $4 \times 10^{2}$ & 0 & 0 & 0 & 0 \\
\hline Amostra 33 & $5 \times 10^{2}$ & 0 & 0 & 0 & 0 \\
\hline Amostra 34 & $4 \times 10^{2}$ & 0 & 0 & 0 & 0 \\
\hline Amostra 35 & $5 \times 10^{2}$ & 0 & 0 & 0 & 0 \\
\hline Amostra 36 & $5 \times 10^{3}$ & 0 & 0 & 0 & 0 \\
\hline Amostra 37 & $2 \times 10^{2}$ & 0 & 0 & 0 & 0 \\
\hline Amostra 38 & $5 \times 10^{2}$ & 0 & 0 & 0 & 0 \\
\hline Amostra 39 & $5 \times 10^{2}$ & $1 \times 10^{1}$ & 0 & 0 & 0 \\
\hline Amostra 40 & $2 \times 10^{2}$ & 0 & 0 & 0 & 0 \\
\hline Amostra 41 & $3 \times 10^{2}$ & 0 & 0 & 0 & 0 \\
\hline Amostra 42 & $2 \times 10^{3}$ & 0 & 0 & 0 & 0 \\
\hline Amostra 43 & $1 \times 10^{3}$ & $1 \times 10^{1}$ & 0 & 0 & 0 \\
\hline Amostra 44 & $3 \times 10^{2}$ & 0 & 0 & 0 & 0 \\
\hline
\end{tabular}




\begin{tabular}{|c|c|c|c|c|c|}
\hline Amostra 45 & $4 \times 10^{2}$ & $1 \times 10^{1}$ & 0 & $1 \times 10^{1}$ & 0 \\
\hline Amostra 46 & $3 \times 10^{2}$ & 0 & 0 & 0 & 0 \\
\hline Amostra 47 & $3 \times 10^{3}$ & $1 \times 10^{1}$ & $1 \times 10^{1}$ & 0 & 0 \\
\hline Amostra 48 & $2 \times 10^{3}$ & 0 & 0 & 0 & 0 \\
\hline Amostra 49 & $3 \times 10^{2}$ & 0 & 0 & 0 & 0 \\
\hline Amostra 50 & $2 \times 10^{2}$ & 0 & 0 & 0 & 0 \\
\hline
\end{tabular}

F.E: Feixe de Elétrons; R.G: Radiação Gama.

\subsection{Efeito da Radiação gama e feixe de elétrons em aflatoxinas}

Para a utilização da metodologia descrita, foram avaliados os seguintes parâmetros: recuperação, repetibilidade e limite de quantificação.

De acordo com o Instituto Nacional de Metrologia, Qualidade e Tecnologia (INMETRO) (2003), a recuperação expressa a precisão de uma metodologia, sendo estimada pela adição de quantidades conhecidas do analito em uma determinada amostra. A repetibilidade é utilizada para avaliar a dispersão dos resultados entre ensaios independentes, repetidos de uma mesma amostra, e em condições definidas. O limite de quantificação (LQ) é definido como a menor concentração do analito que pode ser determinada com nível aceitável de precisão. As amostras foram quantificadas através de curva de calibração construída a cada lote ("batch").

\subsubsection{Curva de calibração para aflatoxinas}

O valor final de massa injetada no cromatógrafo corresponde a $1 \mathrm{~g}$ de amostra. Dessa forma, as curvas de calibração para as aflatoxinas, com 5 pontos e em quintuplicata, foram realizadas injetando-se soluções derivatizadas dos padrões nas concentrações de 0,625 ng/mL; $1,25 \mathrm{ng} / \mathrm{mL} ; 2,5 \mathrm{ng} / \mathrm{mL} ; 5 \mathrm{ng} / \mathrm{mL}$ e $10 \mathrm{ng} / \mathrm{mL}$ para cada aflatoxina. Essas concentrações correspondem aos valores de $0,25 \mu \mathrm{g} / \mathrm{kg} ; 0,5 \mu \mathrm{g} / \mathrm{kg} ; 1,0 \mu \mathrm{g} / \mathrm{kg} ; 2,0 \mu \mathrm{g} / \mathrm{kg}$ e $4 \mu \mathrm{g} / \mathrm{kg}$.

Os valores dos coeficientes de correlação foram de 0,999 para todas as aflatoxinas.

\subsubsection{Limites de detecção (LD) e quantificação (LQ) para aflatoxinas}

A determinação dos LD e LQ seguiram protocolo padronizado por Reis et al., (2012).

O LD foi a menor concentração que pode ser determinada como sendo diferente da amostra branco (livre de aflatoxinas). Os valores estimados para LD foram baseados na 
relação de 5 vezes o ruído da linha de base e determinado através de análises de soluções de padrão de cada aflatoxina, diminuindo as concentrações até o menor nível detectável (IUPAC; CURRIE, 1999).

LQ foi o nível o qual os resultados puderam ser obtidos com um grau específico de confiança (IUPAC; CURRIE, 1999). O LQ foi determinado pela análises de soluções padrão de cada aflatoxinas, diminuindo as concentrações até o menor nível quantificado com precisão e acurácia aceitáveis.

Desta forma, para amêndoas castanha-do-Brasil, os limites de quantificação e detecção para todas as aflatoxinas foi $1,5 \mathrm{ng} / \mathrm{g}$ e $0,75 \mathrm{ng} / \mathrm{g}$, respectivamente.

\subsubsection{Teste de recuperação para aflatoxinas}

Para o teste de recuperação de aflatoxinas foi feita a inoculação de solução padrão quantificada em amostras de castanha-do-Brasil (amêndoas), que apresentaram níveis de aflatoxinas não detectados. Os testes foram realizados em quintuplicata. A inoculação da solução-padrão foi correspondente à concentração de $10 \mathrm{ng} / \mathrm{g}$ de cada aflatoxina na matriz. A partir da inoculação, executaram-se as etapas de extração e quantificação por CLAE, previamente descritas. Foram realizados, também, os cálculos do percentual de recuperação para cada aflatoxina.

Os coeficientes de recuperação para aflatoxinas foram: $\mathrm{B}_{1}, 80,44 \% ; \mathrm{B}_{2}, 83,28 \% ; \mathrm{G}_{1}$, $116,06 \%$ e $\mathrm{G}_{2}, 84,26 \%$.

\subsubsection{Análise de aflatoxinas}

Das 50 amostras analisadas, antes da inoculação artificial, 12\% (6/50) apresentaram níveis acima do limite estabelecido pela legislação brasileira de $10 \mu \mathrm{g} / \mathrm{kg}$. 


\subsubsection{Feixe de elétrons e radiação gama}

O efeito da radiação por feixe de elétrons e radiação gama foi demonstrado na tabela 2 , onde constatou-se, de acordo com a análise estatística, diferença significativa entre a amostras controle (0 kGy) e as irradiadas.

Tabela 2- Distribuição da concentração de aflatoxinas por tratamento.

\begin{tabular}{lccccc}
\hline Tratamento & N & Média & DP & Mínimo & Máximo \\
\hline Concentração Inicial & 50 & 4,749 & 4,871 & ND & 19,82 \\
5 kGy F.E & 50 & 2,217 & 3,332 & ND & 15,138 \\
5 kGy R.G & 50 & 1,396 & 2,545 & ND & 8,941 \\
10 kGy F.E & 50 & 1,631 & 2,871 & ND & 14,539 \\
10 kGy R.G & 50 & 0,753 & 1,711 & ND & 6,755 \\
\hline
\end{tabular}

F.E = Feixe de Elétrons; R.G = Radiação Gama; DP = Desvio Padrão; ND=não detectado.

Análise de aflatoxinas nas amostras artificialmente inoculadas demonstram, após irradiação com feixe de elétrons na dose de 5 kGy, redução de 53,3\% na concentração de aflatoxinas. Já na dose de 10 kGy constatou-se diminuição de 65,66\% da toxina. Tais resultados vem ao encontro daqueles obtidos por Rogovschi et al. (2009), utilizando meio de ágar coco inoculado com $A$. flavus produtor de $\mathrm{AFB}_{1}$. Os autores observaram redução de 75,49\% na concentração de $\mathrm{AFB}_{1}$, após dose de $5 \mathrm{kGy}$ de feixe de elétrons. A eficácia da irradiação com feixes de elétrons também foi constatada por Shahbaz et al. (2010), utilizando graõs de milho irradiados com doses de 10, 15, 20 e $25 \mathrm{kGy}$. Os percentuais de redução dos níveis AFB1 foram de 11, 23, 46 e 66\%, respectivamente.

Recentemente a utilização de aceleradores de elétrons foi considerada uma nova alternativa de irradiação. Os radicais livre gerados, altamente reativos, além de controlar o crescimento fúngico podem atacar o anel furano terminal da $\mathrm{AFB}_{1}$ gerando produtos de baixa atividade biológica (RUSTOM, 1997; TSAI, 2006)

Uma outra vantagem da irradiação por feixe de elétrons é o menor tempo de irradiação, porém, há de se destacar sua baixa penetrabilidade (RUSTOM, 1997;TSAI, 2006).

A espessura do material e sua densidade são importantes na penetrabilidade do processo, por exemplo, em um material com densidade semelhante a da água, o poder de 
penetração de um feixe de elétron com $10 \mathrm{MeV}$ é de $5 \mathrm{~cm}$, enquanto que por radiação gama com cobalto-60 com energia de $1,25 \mathrm{MeV}$ é de cerca de $50 \mathrm{~cm}$. Devido à irregularidade da forma das amêndoas, embalamos as amostras de forma compacta (Apêndice, figura 5.AP), visando uma melhor distribuição da irradiação por feixe de elétrons na amostra (SATO, 1993).

A maior eficácia da radiação gama, comparativamente ao feixe de elétrons, também pode ser constatada, nas duas doses empregadas. A redução de AFB1 foi mais eficiente com o emprego de $10 \mathrm{kGy}$, comparativamente à dose de $5 \mathrm{kGy}$. Os percentuais de redução foram de 70,61\% (5 kGy) e de 84,15\% (10kGy). Segundo Aquino et al. (2005), dose de 10 kGy de raios gama, foi efetiva para a eliminação total de aflatoxinas em amostras de milho. Em trabalho realizado com amendoim nas doses de 15 kGy, 20kGy, 25 kGy e 30 kGy de radiação gama, resultaram redução de 55-74\% de $\mathrm{AFB}_{1}$ (PRADO, 2003).

O uso da radiação gama para inativação de aflatoxinas também foi investigado por Rustom (1997). Segundo o autor, a presença de água tem um importante papel na destruição de aflatoxinas, devido a radiólise da água levar a formação de radicais livres altamente reativos que, da mesma forma da radiação por feixe de elétrons, atacam o anel furano terminal da $\mathrm{AFB}_{1}$.

Temcharoen e Thilly (1982), analisando amostras de alimento à base de amendoim previamente inoculada com aflatoxina $\mathrm{B}_{1}\left(\mathrm{AFB}_{1}\right)$, observaram redução de $75 \%$ e $100 \%$ após a irradiação gama, respectivamente nas doses de 1 e $10 \mathrm{kGy}$. Em estudo feito com grãos de milho foi demonstrada a redução em 14, 24, 49 e 69\% utilizando radiação gama nas doses de 10, 15, 20 e 25 kGy respectivamente (SHAHBAZI et al., 2010).

Observando a média da concentração e a porcentagem de $\mathrm{AFB}_{1}$ das amostras inoculadas antes e após passarem pelos processos de radiação, podemos perceber que todos os processos foram eficientes e não apresentaram diferença estatística entre si. Tratando-se de análises de médias de quantificação de $\mathrm{AFB}_{1}$, a radiação gama mostrou maior eficiência do que o feixe de elétrons, isso pode se dar, principalmente, por seu maior poder de penetrabilidade no alimento.

O Quadro 4 mostra a concentração de AFB1 nas amostras, antes e após os processos de irradiação. 
Quadro 4- Concentração de $\mathrm{AFB}_{1}(\mu \mathrm{g} / \mathrm{kg})$ em amostras antes da inoculação artificial, e após 15 dias de inoculadas (controle) e após os tratamentos por radiação ionizante.

\begin{tabular}{|c|c|c|c|c|c|c|}
\hline \multirow[b]{2}{*}{ Amostras } & \multirow[b]{2}{*}{$\begin{array}{l}\text { Amostras } \\
\text { antes a } \\
\text { inoculação }\end{array}$} & \multicolumn{5}{|c|}{ Subdivisões } \\
\hline & & $\begin{array}{c}\text { Controle } \\
\text { Após } 15 \\
\text { dias }\end{array}$ & $\begin{array}{c}\text { Após } \\
\text { irradiação } \\
\text { com FE- } \\
5 \mathrm{kGy}\end{array}$ & $\begin{array}{c}\text { Após } \\
\text { irradiação } \\
\text { com FE- } \\
10 \mathrm{kGy}\end{array}$ & $\begin{array}{c}\text { Após } \\
\text { irradiação } \\
\text { com RG- } \\
5 \mathrm{kGy}\end{array}$ & $\begin{array}{c}\text { Após } \\
\text { irradiação } \\
\text { com RG- } \\
10 \mathrm{kGy}\end{array}$ \\
\hline Amostra 01 & 11,075 & 15,964 & 9,959 & 7,675 & 6,339 & 3,696 \\
\hline Amostra 02 & 10,102 & 12,219 & 6,524 & 5,045 & 9,679 & 6,755 \\
\hline Amostra 03 & ND & 1,182 & ND & 1,110 & ND & ND \\
\hline Amostra 04 & ND & 19,820 & 10,723 & 7,887 & 4,824 & 6,735 \\
\hline Amostra 05 & 11,089 & 12,833 & 5,616 & 5,514 & 4,521 & 4,932 \\
\hline Amostra 06 & 10,077 & 10,713 & 8,176 & 8,941 & 1,900 & 4,046 \\
\hline Amostra 07 & ND & 3,078 & 3,021 & ND & 2,634 & ND \\
\hline Amostra 08 & ND & 5,003 & 1,257 & ND & 1,254 & ND \\
\hline Amostra 09 & ND & 4,383 & 3,102 & ND & 1,874 & ND \\
\hline Amostra 10 & ND & 7,327 & 2,560 & 3,538 & 4,645 & ND \\
\hline Amostra 11 & ND & 6,626 & ND & ND & ND & ND \\
\hline Amostra 12 & ND & ND & ND & ND & ND & ND \\
\hline Amostra 13 & ND & 4,659 & ND & 0,912 & ND & ND \\
\hline Amostra 14 & ND & 5,926 & 1,670 & ND & ND & ND \\
\hline Amostra 15 & ND & 8,154 & 2,509 & 1,863 & ND & 0,917 \\
\hline Amostra 16 & ND & 4,478 & 3,413 & ND & 1,941 & ND \\
\hline Amostra 17 & ND & 6,113 & 3,165 & ND & ND & ND \\
\hline Amostra 18 & ND & 4,750 & ND & ND & ND & ND \\
\hline Amostra 19 & ND & 8,416 & 4,015 & ND & 4,951 & ND \\
\hline Amostra 20 & ND & 8,121 & 6,021 & ND & 2,915 & ND \\
\hline Amostra 21 & ND & $\mathrm{ND}$ & $\mathrm{ND}$ & ND & $\mathrm{ND}$ & ND \\
\hline Amostra 22 & ND & ND & ND & ND & ND & ND \\
\hline Amostra 23 & ND & 5,962 & 1,785 & ND & $\mathrm{ND}$ & ND \\
\hline Amostra 24 & 12,003 & 15,946 & 15,138 & 7,626 & 14,539 & 4,205 \\
\hline Amostra 25 & 11,030 & 14,316 & 2,041 & 2,031 & ND & ND \\
\hline Amostra 26 & ND & 10,214 & 7,676 & 7,600 & 2,983 & ND \\
\hline Amostra 27 & ND & 3,174 & 2,933 & 2,265 & 1,631 & 1,897 \\
\hline Amostra 28 & ND & 7,189 & 3,756 & 3,291 & 7,189 & ND \\
\hline Amostra 29 & $\mathrm{ND}$ & 2,692 & 1,032 & ND & 1,421 & 0,810 \\
\hline Amostra 30 & ND & 0,601 & ND & ND & ND & $\mathrm{ND}$ \\
\hline Amostra 31 & ND & 1,751 & ND & ND & ND & ND \\
\hline Amostra 32 & $\mathrm{ND}$ & 2,583 & ND & ND & $\mathrm{ND}$ & $\mathrm{ND}$ \\
\hline Amostra 33 & ND & 2,260 & ND & ND & ND & ND \\
\hline Amostra 34 & ND & 1,532 & ND & ND & ND & ND \\
\hline Amostra 35 & ND & 1,356 & 1,125 & 0,867 & ND & ND \\
\hline Amostra 36 & ND & 1,576 & 1,327 & 1,117 & 1,285 & 1,330 \\
\hline Amostra 37 & ND & 1,505 & 1,019 & 1,034 & 1,277 & 0,887 \\
\hline
\end{tabular}




\begin{tabular}{|c|c|c|c|c|c|c|}
\hline Amostra 38 & ND & 1,170 & ND & ND & ND & ND \\
\hline Amostra 39 & ND & 1,470 & ND & ND & ND & ND \\
\hline Amostra 40 & ND & ND & ND & ND & ND & ND \\
\hline Amostra 41 & ND & 1,079 & ND & ND & ND & ND \\
\hline Amostra 42 & ND & 1,419 & ND & ND & ND & ND \\
\hline Amostra 43 & ND & ND & ND & ND & ND & ND \\
\hline Amostra 44 & ND & 3,323 & 1,311 & 0,876 & 1,220 & 0,988 \\
\hline Amostra 45 & ND & 2,360 & ND & ND & 1,990 & ND \\
\hline Amostra 46 & ND & 1,061 & ND & ND & ND & ND \\
\hline Amostra 47 & ND & 1,895 & ND & ND & ND & ND \\
\hline Amostra 48 & ND & 0,772 & ND & ND & ND & ND \\
\hline Amostra 49 & ND & ND & ND & ND & ND & ND \\
\hline Amostra 50 & ND & 1,129 & ND & ND & 0,955 & ND \\
\hline
\end{tabular}

ND: Não detectado; LD: 0,75 $\mu \mathrm{g} / \mathrm{kg}$

Obs: Amostras com concentrações acima de $4 \mu \mathrm{g} / \mathrm{kg}$ foram rediluídas e o cálculo da concentração foi feito conforme a diluição. 


\subsection{Análise sensorial}

Os resultados da análise sensorial foram avaliados estatisticamente pela análise de variância ANOVA com médias anaalisadas pelo teste Tukey $(\mathrm{p}<0,05)$, utilizando o software Graphpad prism 5. Nos gráficos, 1, 2 e $3 \mathrm{o}$ * indica a significância estatística dos tratamentos em relação ao controle $(\mathrm{p}<0,05)$.

Em relação ao odor, todos os tratamentos demonstraram diferença significativa ( $\mathrm{p}<$ 0,05), quando comparado ao grupo controle (Gráfico 1).

Gráfico 1- Análise estatística das notas atribuídas pelos julgadores para a característica de odor de castanha-do-Brasil irradiada.

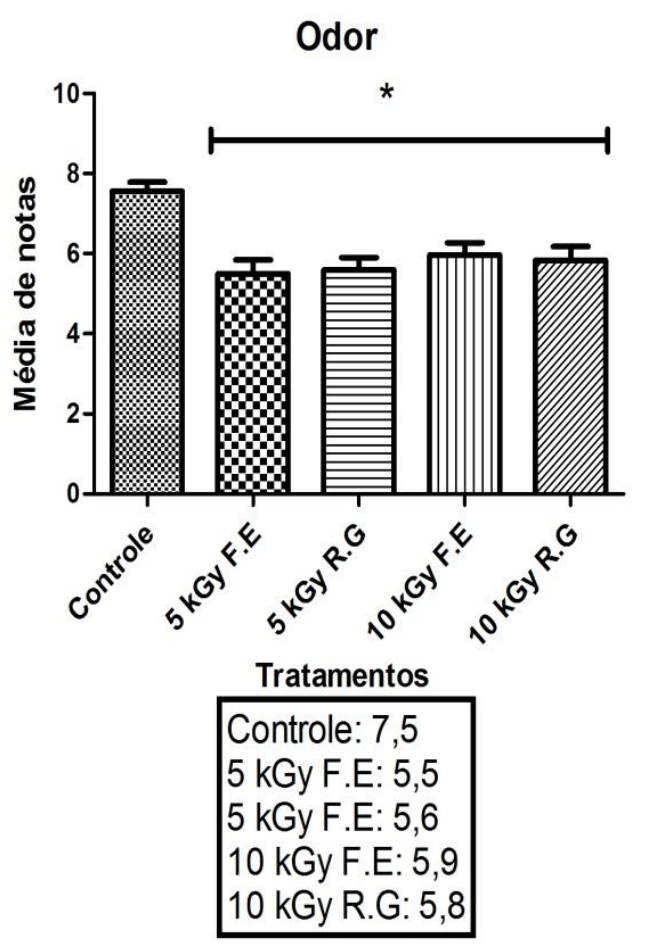

Em relação ao sabor, as amostras irradiadas com com feixe de elétrons (5 kGy) e de radiação gama (5 e $10 \mathrm{kGy})$, apresentaram diferença significativa $(p<0,05)$, em relação a amostra controle. Já o tratamento por feixe de elétrons na dose de 10 kGy não demonstrou diferença significativa, ou seja, os provadores não notaram diferença sensorial em relação ao sabor comparado a amostra controle (Gráfico 2). 
Gráfico 2 - Médias das notas atribuídas pelos julgadores para a característica de sabor de castanha-do-Brasil irradiada.

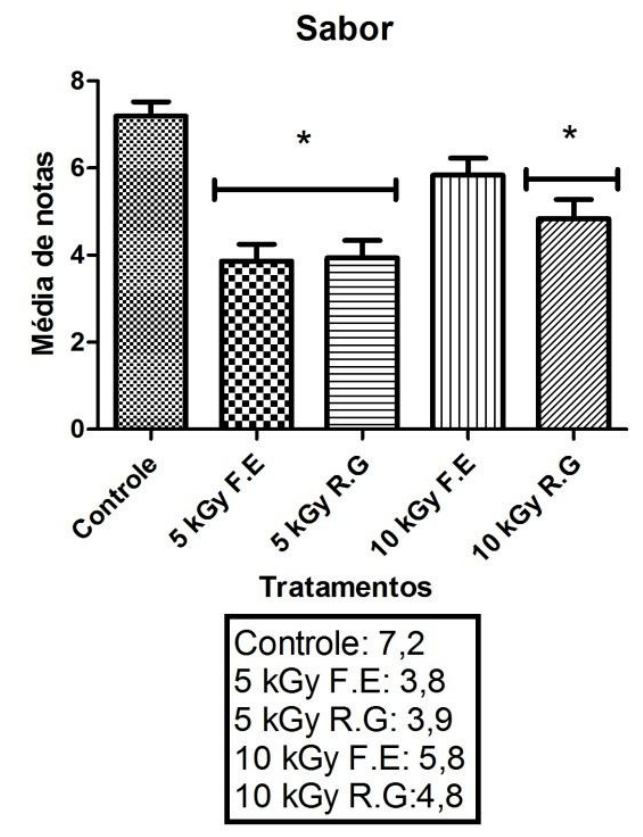

Avaliando a textura, as amostras com tratadas com feixe de elétrons (5kGy) e radiação gama (5 e $10 \mathrm{kGy)}$ apresentaram diferença significativa, quando comparados as amostras controle. Já a avaliação das amêndoas irradiadas com 10 kGy por Feixe de elétrons, não demonstrou diferença estatística de textura comparada às amostras controle. (Gráfico 3).

Gráfico 3 - Médias das notas atribuídas pelos julgadores para a característica de textura de castanha-do-Brasil irradiada.

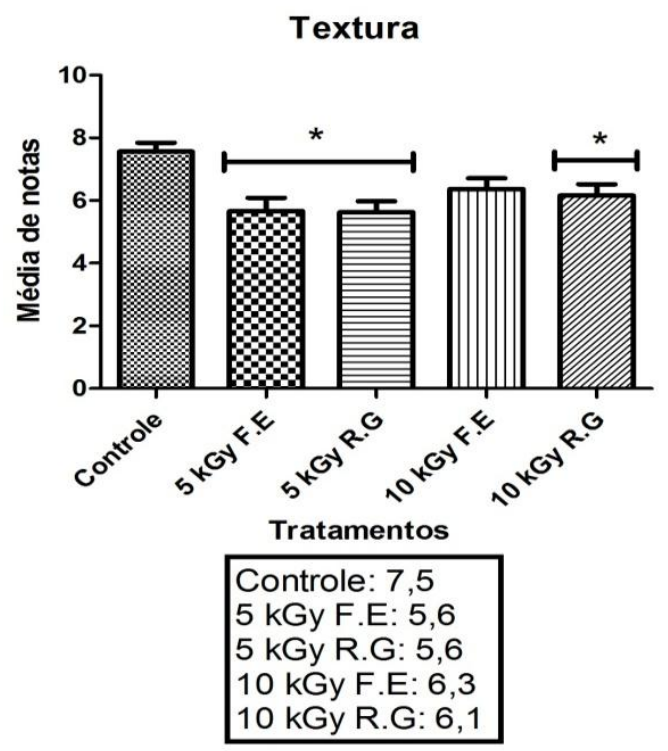


Conforme a média das notas atribuídas e a análise estatística, observamos que comparado odor, sabor e textura, a amostra que mais se aproximou das características sensoriais do controle na aceitação dos provadores foi a amostra irradiada com $10 \mathrm{kGy}$ por feixe de elétrons.

Os principais comentários a respeito das amostras irradiadas com feixe de elétrons, principalmente na dose $5 \mathrm{kGy}$ foram: Gosto de queimado, gosto defumado, rançoso, queimado, torradas. Por sua vez, as amostras irradiadas com raios gama, principalmente aquelas irradiadas com $10 \mathrm{kGy}$, revelaram sabor um pouco rançoso e oleosidade acentuada, porém, foi a essa amostra a atribuição das maiores notas. 


\section{CONCLUSÕES}

- Foi constatada presença de $\mathrm{AFB}_{1}$ acima de $10 \mu \mathrm{g} / \mathrm{kg}$ em 12\% (6/50) das amostras inicialmente analisadas e adquiridas no mercado varejista da cidade de São Paulo;

- ambos os processos de irradiação apresentaram redução da micobiota, porém a Radiação Gama mostrou maior eficiência, provavelmente devido a maior penetrabilidade desse processo;

- através da análise de aflatoxinas verificamos que todos os processos de radiação foram eficientes, porém segundo os resultados de quantificação de $\mathrm{AFB}_{1}$, a radiação gama demonstrou maior capacidade de eliminação da $\mathrm{AFB}_{1}$ presente nas amostras;

- a análise sensorial avaliando odor, sabor e textura da castanha-do-Brasil, demonstrou maior aceitação da amostra controle e a que mais se aproximou da média de aceitação foi a amostra irradiada com Feixe de elétrons na dose de 10 kGy;

- a utilização do feixe de elétrons pode ser inviável para uma grande quantidade de amostras, pois a irregularidade da forma das amêndoas dificulta a homogeneidade da radiação;

- a penetrabilidade da radiação gama mostrou-se mais eficiente, já que as castanhas apresentam estrutura irregular, o que poderia dificultar a utilização de feixe de elétrons. 


\section{REFERÊNCIAS ${ }^{*}$}

ALEIXO, P. C.; NÓBREGA, J. A.; JÚNIOR, D. S.; MULLER, C. S. Determinação direta de selênio em água de coco e em leito de coco utilizando espectrometria de absorção atômica com atomização eletrotérmica em forno grafite. Art. Rev. Química Nova, p. 210-312, 2000.

ALHO, C. J. R. Proteção da floresta mais benefícios sociais. Ciência Hoje, v. 25, p. 31-37, 1999.

ALMEIDA, F.; AZEVEDO, P. C. O gênero Aspergillus e a podridão da castanha-do-pará. Paramédico, v. 50, jan./mar. 1950.

AMORIM, S. S.; SILVA, C. M. G.; PIRES, R. A.; SANTOS, E. A.; CASTRO, L.; SA, T. A. Occurrence of Mycotoxins in Food and Feed in Brazil. In: OFFICIAL PROGRAM AND ABSTRACT BOOK OF THE 10TH INTERNATIONAL IUPAC SYMPOSIUM ON MYCOTOXIN AND PHYCOTOXIN, 2000, São Paulo. Abstracts... São Paulo, 2000. p. 141.

AN-HUNG, F. U.; SEBRANEK, J. G.; MURANO. E. A. Suviral of Listeria monocytogenes and Salmonella typhimurium and quality attributes of cooked pork chops and cured ham after irradiation. J. Food Sci., v. 60, n. 5, p. 1001-1008, 1995.

ANSCI (DEPARTAMENT OF ANIMAL SCIENCE). Aflatoxins: occurrence and health risks. Plants poisonous to livestock. Cornell University. Disponível em: <http://www.ansci.cornell.edu/plants/toxicagents/aflatoxin/aflatoxin.html>. Acesso em: 07 Aug 2012.

ASSOCIATION OF OFFICIAL ANALYTICAL CHEMISTS (AOAC). Official methods of analysis of the 18th international AOAC. In: HORWITZ, W.; LATIMER, G. W. (Ed.) Official methods of analysis of the 18th international AOAC. Published by AOAC International. Gaithersburg, 2005.

APPLEBAUM, R. S.; BRACKETT, R. E.; WISEMAN, D. W.; MARTH, E. H. Responses of dairy cows to dietary aflatoxin: feed intake and yeld, toxin content, and quality of milk of cows treated with pure and impure aflatoxin. J. Dairy Sci., v. 65, p. 1503-1508, 1982.

AQUINO, S. Efeitos da radiação gama no crescimento de Aspergillus flavus produtor de aflatoxinas e no emprego da técnica da reação em cadeia da polimerase (PCR) em amostras de grão de milho inoculadas artificialmente. 2003. 89 f. Dissertação (Mestrado em Tecnologia Nuclear) - Instituto de Pesquisas Energéticas e Nucleares, Universidade de São Paulo, São Paulo, 2003.

AQUINO, S. Gamma radiation against toxigenic fungi in food, medicinal and aromatic herbs. In: MENDEZ, V. (Ed.). Science against microbial pathogens: communicating current research and technological advances. 2011. p. 272-281.

\footnotetext{
* De acordo com:

ASSOCIAÇÃO BRASILEIRA DE NORMAS TÉCNICAS. NBR 6023: informação e documentação: referências: elaboração. Rio de Janeiro, 2002.
} 
AQUINO, S.; FERREIRA, F.; RIBEIRO, D. H. B.; CORRÊA, B.; GREINER, R.; VILLAVICENCIO, A. L. C. H. Evaluation of viability of Aspergillus flavus and aflatoxinas degradation in irradiated samples of maize. Brazilian Journal of Microbiology, v. 36, p. 352-356, 2005.

ARRUS, K.; BLANK, G.; ABRAMSON, D.; CLEAR, R.; HOLLEY, R.A. Aflatoxin production by Aspergillus flavus in Brazil nuts. Journal of Stored Products Research, v. 41, p. 513-527, 2005.

AZIZ, N. H. et al. Effect of gamma radiation on the survival of fungal and actinomycetal florae contaminating medicinal plants. Appl. Radiat. Isot., v. 48, n. 1, p. 71 -76, 1997.

BAQUIÃO, A. C. Fungos e micotoxinas em castanhas-do-Brasil, da colheita ao armazenamento. 2012. 141 f. Tese (Doutorado em Microbiologia) - Instituto de Ciências Biomédicas, Universidade de São Paulo, São Paulo, 2012.

BAQUiÃO, A. C., ZORZETE, P., REIS, T. A., ASSUnÇÃO, E., VERGUEIRO, S. \& CORREAA, B. Mycoflora and mycotoxins in field samples of Brazil nuts. Food Control, v. 28, p. 224-229, 2012.

BENNET, J. W. Aspergillus: a primer for the novice. Med. Mycol., v. 47, p. S1-S8, 2009.

BENNET, J. W.; KLICH, M. Mycotoxins. Clinical Microbiology Reviews, Washington, v. 16, n. 3, p. 497-516, 2003.

BINDER, E. New descontamination techniques. In: SCUSSEL, V. M. (Ed.) Atualidades em micotoxinas e armazenagem de grãos. Florianópolis, 2000. p. 186-194.

BITANCOURT, A. A. Podridões da castanha-do-pará. Biológico, v. 7, p. 303-312, 1949.

BLOUNT, W. P. Turkey X disease. Turkeys, v. 9, n. 2, p. 52-67, 1961.

BORRELY, S. I. Tratamento de esgoto sanitário com uso de acelerador de elétrons. 1995, 104 f. Dissertação (Mestrado em Tecnologia Nuclear) - Instituto de Pesquisas Energéticas e Nucleares, Universidade de São Paulo, São Paulo, 1995.

BRASIL. Ministério da Agricultura, Pecuária e Abastecimento. Prevenção de aflatoxinas em castanha-do-Brasil: cartilha do produtor. Brasília, 2000.

BRASIL. Ministério da Agricultura, Pecuária e Abastecimento. Cenário de exportações de castanha-do-Brasil 2000-2010. Apresentação câmara setorial de fruticultura, Ministério da Agricultura, Pecuária e Abastecimento. Brasília, 2010. 15 p.

BULLERMAN, L. B. Significance of mycotoxins to food safety and human health. J. Food Prot., v. 42, n. 1, p. 65-86, 1979.

BU'LOCK, J. D. Mycotoxins as secondary metabolities. In: STAY, P. S. (Ed.). The biosynthesis of mycotoxins. New York: Academy Press, 1980. p. 1-16. 
BUSTA, F. F.; PETERSON, E. H.; ADAMS, D. M. Colony count methods. In: SPECK, M. L. (Ed.). Compendium of methods for the microbiological examination of methods for the microbiological examination of foods. New York: American Public Health Association, 1984. p. 914.

BUXTON, G. V. Radiation chemistry: principles and applications. In: FARHATAZIZ, RODGERS, M. A. J. (Ed.). Radiation chemistry: principles and applications. Weinheim, Germany: Verlag Chemie Publishers, 1987. p.641.

CAER, S. L. Water radiolysis: influence of oxide surfaces on $\mathrm{H} 2$ production under ionizing radiation. Journal Water, v. 3, p. 235-253, 2011.

CALDAS, E. D.; SILVA, S. C.; OLIVEIRA, J. N. Aflatoxinas e ocratoxina A em alimentos e riscos para a saúde humana. Rev. Saúde Pública, v. 36, p. 319-323, 2002.

CALVO, W. A. P. Desenvolvimento do sistema de irradiação em um irradiador multipropósito de cobalto-60 tipo compacto. 2005. 119 f. Dissertação (Doutorado em CNA - Aplicações) - Instituto de Pesquisas Energéticas e Nucleares, Universidade de São Paulo, São Paulo, 2005.

CAMARGO, A. C; WALDER, J. M. M. Princípios da irradiação. Divulgação da tecnologia de irradiação de alimentos e outros materiais. CENA/PCLQ. Disponível em: <http://www.cena.usp.br/irradiacao/principios.htm> Acesso em: 02 set. 2012.

CAMPBELL, C.; STOLOFF, L. Implication of mycotoxins for human health. J. Agric. Food Chem., v. 22, p. 1006-1015, 1974.

COUNCIL FOR AGRICULTURAL SCIENCE AND TECHNOLOGY (CAST); RICHARD, J. L.; PAYNE, G. A. (Ed.) Mycotoxins: risks in plant, animal and human systems. Iowa, USA: Task Force Report, 2003. n. 139.

CASTRO, M. F. P. M.; SOARES, L. M. V.; FURLANI, R. R. Z. Mycoflora, aflatoxigenic species and mycotoxins in freshly harvest corn (Zea Mays. L.): a preliminary study. Rev. Microbiol., v. 26, p. 289-295, 1995.

CHOURASIA, H. K.; ROY, A. K. Effect of temperature, relative humidity and light on aflatoxin $\mathrm{B}_{1}$ production in neem and Datura seeds. Int. J. Pharmacognosy., Lisse, v. 29, p. 197-202, 1991.

CHRISTENSEN, C. M.; SAUER, D. B. Mycoflora. In: CHRISTENSEN, C. M. (Ed.). Storage of cereal grains and their products. Minnesota: American Association of Cereal Chemists, 1982. p. 219-240.

CHU, F. S. Mycotoxins: food contamination, mechanism, carcinogenic potential and preventive measures. Mutatation Research, v. 259, n. 3-4, p. 291-306, 1991.

CIEGLER, A. Fungi that produce mycotoxins: condition and occurrence. Mycopathology, v. 65, p. 5-11, 1978. 
CLAY, J. W.; CLEMENTE, C. R. Selected species and strategies to enhance income generation from Amazonian Forests. Rome: FAO, Forestry Paper, 1993.

CONKOVÁ, E. et al. Fusarial toxins and their role in animal diseases. Vet. Journal., v. 165, n. 3, p. 214-220, 2003.

CORRE, F. L.; VENAILLE, L. Tratamientos con radiaciones ionizantes, In: BOURGEOIS, C. M.; MESCLE, J. F.; ZUCCA, J. Microbiologia alimentaria 1: aspectos microbiológicos de la seguridad y calidad alimentaria. España: Acribia, 1988. Cap. 4, p. 357-381.

COTTY, P. J.; BAYMAN, P.; EGEL, D. S.; ELIS, K. S. Agriculture, aflatoxins and Aspergillus. In: POWELL, K. A.; RENWICK, A.; PEBERDY, J. F. (Ed.). The Genus Aspergillus: from taxonomy and genetics to industrial applications. New York: Plenum Press, 1994. p. 1-27.

COUTINHO, V. F.; BITTENCOURT, V. B.; COZZOLINO, S. M. F. Effects of supplementation with Brazil nuts (CP, Bertholletia excelsa, H.B.K.) in capoeira players on selenium (Se) concentration and glutathione peroxidase activity (GSH-PX, E. C. 1.11.1.9). In: ROUSSEL, A. M.; ANDERSON, R. A.; FRAVIER, A. E. (Ed.). Trace elements in man and animal. New York: Springer, 2002. pt. 2, p. 405-406.

DIEHL, J. F. Food irradiation: is it an alternative to chemicals preservatives. Food Addit. Contam., v. 9, p. 409-416, 1992.

DIEHL, J. F. Safety of irradiated foods. New York: Marcel Dekker, 1995.

DUBOIS, J. C. L. A origem e a importância sócio-economica dos castanhais silvestres da Amazônia. Seção Artigos REBRAF, Disponível em: <http://www.rebraf.org.br/cgi/cgilua.exe/sys/start.htm?infoid=22\&sid=2> Acesso em: 14 junho, 2012.

DUBOIS, J. C. L. Utilização do potencial extrativista das florestas Amazônicas: soluções encontradas pelo homem na Amazônia. Seropédica, RJ: Depto de Fitotecnia/UFRRJ, 1996.

ETZEL, R. A. Mycotoxins. Jama, v. 287, n. 4, p. 425-427, Jan. 2002.

FOOD AND AGRICULTURAL ORGANIZATION OF THE UNITED NATIONS (FAO); INTERNATIONAL AGENCY OF ENERGY ATOMIC (IAEA). Training manual on food irradiation technology and techniques. 2nd ed. Vienna: IAEA, 1982.

FARKAS, J. Principios de la irradiación de alimentos. In: La Irradiacion de Alimentos e en Latinoamérica, Octubre 24-28, 1983. Lima, Perú: Proceedings.. Vienna: OIEA, 1985. p. 1123.

FOOD AND DRUG ADMINISTRATION (FDA). Packaging for foods treated with ionizing radiation: irradiated foods e packaging. Disponível em: $<$ http://www.fda.gov/food/foodingredientspackaging/irradiatedfoodpackaging/ucm081399.ht m). Acesso em: 04 Sep 2012. 
FELBERG, I. et al. Bebida mista de extrato de soja integral e castanha-do-Brasil: caracterização físicoquímica, nutricional e aceitabilidade do consumidor. Rev. Alim. Nutr., v. 15, n. 2, p. 163-174, 2004.

FERREIRA, F. L. Efeitos da radiação gama sobre amostras de milho contaminadas com

Fusarium verticillioides. 121 f. 2005. Dissertação (Mestrado em Ciências) - Instituto de Ciências Biomédicas, Universidade de São Paulo, São Paulo, 2005.

FERREIRA-CASTRO, F. L. et al. Effects of gamma radiation on maize samples contamineted with Fusarium verticillioides. Appl. Rad. Isotopes, v. 65, p. 927-933, 2007.

FERREIRA-CASTRO, F. L. Interação entre fungos toxigênicos (Aspergillus flavus e Fusarium verticillioides) e carunchos (Sitophillus zeamais) em amostras de grãos de milho. 2011. 111 f. Tese (Doutorado em Microbiologia) - Instituto de Ciências Biomédicas, Universidade de São Paulo, São Paulo, 2011.

FRANK, H. K.; BETANCOUT, L. A. Castanha-do-pará: origem, produção e características físicas e química. Bol. SBCTA, v. 15, n. 4, p. 351-365, 1981.

FREIRE, F. C. O.; KOZAKIEWCZ, Z.; PATERSON, R. R. M. Mycoflora and mycotoxins in Brazilian black pepper, white pepper and Brazil nuts. Mycopathologia, v. 149, p. 13-19, 2000 .

FREITAS, J. B.; NAVES, M. M. V. Composição química de nozes e sementes comestíveis e sua relação com a nutrição e saúde. Rev. Nutr., v. 23, n. 2, p. 269-279, 2010.

GEISEN, R. PCR methods for detection of Mycotoxin - producing Fungi. In: BRIDGE, P. D.; ARORA, D. K.; REDDY, C. A.; ELANDER, R. P. (Ed.). Aplications of PCR in mycology. 2nd ed. Cambrige, UK: Cambridge University Press, 2000. p. 242-263.

GIESEL, F. Uber Radium und radioactive Stoffe. Ber. Dtsch. Chem. Ges., v. 35, p. 3608$3611,1902$.

GOLDBLATT, L. A. Implications of mycotoxins. Clin. Toxicol., v. 5, p. 453-458, 1972.

GONÇALVES, J. F.; FERNANDES, A. V.; OLIVEIRA, A. F. M. Primary metabolism components of seeds from Brazilian Amazon tree species. Brazilian Journal Plant Physiology, v. 14, n. 2, p. 139-142, 2002.

GRANT, I. R.; PATTERSON, M. Effect of irradiation and modified atmosphere packaging on the microbiological safety of minced pork stored under temperature abuse conditions. Int. J. Food Science. Technol., v. 26, p. 521-533, 1991.

HANSEN, J. M.; SHAFFER, H. L. Sterilization and preservation by radiation sterilization. In: BLOCK, S. S. Disinfection sterilization and preservation. 5th ed. Philadelphia: Lippincott Williams e Wilkins, 2001. Chap. 37, p. 729-746.

HARTLEY, R. D.; O'KELLY, J. Toxicity and fluorescence properties of aflatoxins. Nature, v. 196, p. 1001, 1963. 
HUSSEIN, S. H.; BRASEL, J. M. Toxicity, metabolism, and impact of mycotoxins on humans and animals. Toxicology, v. 167, p. 101-134, 2001.

HUWIG, A.; FREIMUND, S.; KÄPPELI, O.; DUTLER, H. Mycotoxin detoxification of animal feed by different adsorbents. Toxicology Letters, v. 122, p. 179-188, 2001.

INTERNATIONAL ATOMIC ENERGY AGENCY (IAEA). Facts about food irradiation. Document for the ICGFI, Vienna, 1999. $53 \mathrm{p}$.

INSTITUTO ADOLFO LUTZ (IAL). Metodos fisíco-químicos para análise de alimentos. 4. ed. São Paulo: Secretaria de Estado da Saúde, 2008. Cap. 6.

INTERNATIONAL AGENCY FOR RESEARCH ON CANCER (IARC). Some naturally occurring substances: food items and constituents, heterocyclic aromatic amines and mycotoxins. IARC. Monographs on the Evaluation of Carcinogenic Risks to Humans, v. 56, p. 445-446, 1993.

INTERNATIONAL ATOMIC ENERGY AGENCY (IAEA). Facts about food irradiation, 1999. Disponivel em: < http://www.iaea.org/Publications/Booklets/foodirradiation.pdf > acesso em: 12/08/2012.

ILENDER (PHARMACEUTICAL CORPORATION). As micotoxinas: problema permanente. Notas Científicas, n. 3, 1999.

INSTITUTO NACIONAL DE METROLOGIA, NORMALIZAÇÃO E QUALIDADE INDUSTRIAL (INMETRO). Orientações sobre validação de métodos de ensaios químicos. Revisão, n. 1, 35 p., 2003.

International Union of Pure and Applied Chemistry and Currie (IUPAC). Commission on Analytical Nomeclature. Recommendations in evalution of analytical Methods Including detection and Quantification Capabilities. Pure and Apllied Chemistry, v. 67, p. 1699-1723, 1999.

JAY, J. M. Microbiologia moderna de los alimentos. 3. ed. Zaragoza: Editorial Acribia, 1994. $753 \mathrm{p}$.

JELINEK, C. F. Distribution of mycotoxin: an analysis of worldwide commodities data, including data from $\mathrm{FAO} / \mathrm{WHO} / \mathrm{UNEP}$ food contamination monitoring programme. Joint FAO/WHO/UNEP. In: INTERNATIONAL CONFERENCE ON MYCOTOXINS, 1987, Bangkok, Thailand. Anais... Bangkok, Thailand, 1987.

KERNBAUM, M. Sur la décomposition de l'eau par les rayons béta du radium et par les rayons ultra-violets. Le Radium, v. 6, p. 225-228, 1909.

KORALIS-BURELlE, N. et al. Compendium of peanut diseases. 2 ed. St. Paul: The American Phytopathological Society, 1997.

KRISHNAMURTHY, Y. L.; SHASHIKALA, J. Inhibition of aflatoxin $\mathrm{B}_{1}$ production of Aspergillus flavus, isolated from soybean seeeds by certain natural plant products. Journal Comp. Letters in Apllied Mycro, n. 43, p. 469-474, 2006. 
LACEY, J. Grain fung. In: ARORA, D. K. et al. Handbook appl. micology: food and feed. New York: Marcel Dekker, 1991. p. 12-77.

LACEY, J.; MAGAN, N. Fungi in cereal grains: their occurrence and water and temperature relationships, In: CHELKOWSKI, J. (Ed.). Cereal grain mycotoxins, fungi and quality in drying and storage. Amsterdam: Elsevier, 1991. p. 77-118.

LANCASTER, M. C.; JENKINS, F. P.; PHILIP, J. McL. Toxicity associated with certain samples of groundnuts. Nature, v. 192, p. 1095, 1961.

LAZZARI, F. Prevenção de Micotoxinas em Alimentos e Rações. In: SCUSSEL, V.M. (Ed.) Atualidades em Micotoxinas e Armazenagem de Grãos. Florianópolis: Ed. da Autora, p. 104-109, 2000.

LEESON, S.; GONZALO, J. D. G.; SUMMERS, J. D. Poultry metabolic disorders and mycotoxins. Ontario, Canada: Univ. Guelph, 1995. p. 299-309.

LEY, F. J.; KENNEDY, T. S.; KAWASHIMA, K.; ROBERTS, D.; HOBBS, B. C. The use of gamma radiation for the elimination of Salmonella from frozen meat. J. Hyg., v. 6, p. 293$311,1970$.

LIMA, F. E. L. Ácidos graxos e doenças cardiovasculares: uma revisão. Rev. [online] Nutr., v. 13, n. 2, p. 73-80, 2000.

LIN, M. T.; DIANESE, J. C. A Coconut-Agar Medium for rapid detection of aflatoxin production by Aspergillus spp. Phytopathology, v. 66, p. 1466-1469, 1976.

LINDSEY, D. L.; TURNER, R. B. Inhibition of growth of Aspergillus flavus and Trichoderma viride by peanut embryos. Mycopathologia, v. 55, p. 149-152, 1975.

LORENZI, H. Árvores brasileiras. 4. ed. São Paulo: Instituto Plantarum, 2000. v. 1.

LORENZI, H. Árvores brasileiras: manual de identificação e cultivo de plantas arbóreas nativas do Brasil. São Paulo: Instituto Plantarium Ltda, 2010. 384 p.

LORINI, I. Controle físico, químico e biológico de pragas de grãos armazenados: inseticidas, resistência e resíduos. In: SCUSSEL, V. M. (Ed.) atualidades em micotoxinas e armazenagem de grãos. Florianópolis, 2000. p. 321-338.

MACKENZIE, D. W. R. Keynote lecture: Aspergillus in man. In: VANDEN BOSSCHE, H.; MACKENZIE, D. W. R.; CAUWENBERGH, G. (Ed.). Aspergillus and Aspergillosis. New York: Plenum Press, 1988. p. 332.

MARKLINDER, I.; LINDBLAD, M.; GIDLUND, A.; OLSEN, M. Consumers ability to discriminate aflatoxin-contamined Brazil nuts. Food Addit. Contam., v. 22, p. 56-64, 2005.

MATSUDA, A. H. Aplicação da técnica de irradiação gama para preservação de própolis. 2002. 86 f. Dissertação (Mestrado em Tecnologia Nuclear) - Instituto de Pesquisas Energéticas e Nucleares, Universidade de São Paulo, São Paulo, 2002. 
MAXY, R. B. Irradiation of food for public health protection. J. Food Prot., v. 45, n. 4, p. 363-366, 1992.

MELLO, F. R.; SCUSSEL, V. M. Characteristics of in shell Brazil nuts and their relationship to aflatoxin contamination: criteria for sorting. J. Agric. Food Chem., v. 55, p. 9305-9310, 2007.

MILLER, J. R. Epidemiology of Fusarium ear diseases of cereals. In: MILLER, J. D.; TRENHOLM, H. L. (Ed.). Mycotoxins in Grain. St. Paul: Eagan Press, 1994. p. 19-36.

MONK, J. D; BEUCHAT, L. R; DOYLE, M. P. Irradiation inactivation of food-borne microrganisms. J. Food Prot., v. 58, n. 2, p. 197-208, 1995.

MOSS, M. O. Recent studies of mycotoxins. J. Appl. Microbiol., v. 84, n. 27, p. 62S-76S, 1998. Suppl.

MOSS, M. O. Mycotoxins of Aspergillus and other filamentous fungi. J. Appl. Bacteriol., p. 69-81, 1989. Suppl.

MURANO, E. A. Irradiation of fresh meats. Food Technol., p. 52-54, 1995.

NATIONAL RESOURCE CENTER ON NUTRITION AND AGING (NAN). Dietary reference intakes (DRIs)/ Recommended Dietary Allowances (RDAs). Dietary Reference Intakes for Older Adults, Florida International University, p. 1, 2004.

NOGUEIRA, S. O fator humano: castanhais podem ser resultado de populações indígenas antes da colonização Européia. Revista FAPESP, n. 198, p. 59, 2012.

NORDION. The history of food irradiation. 5 p. Disponível em: <http://www.nordion.com/documents/the-history-of-food-irradiation.pdf> Acesso em: 09 Sep 2012.

NUCLEAR REGULATORY COMMISSION (NRC). Technical Training Center. Biological effects of radiation. Reactor Concepts Manual, p. 1-23, 2012.

OKUNO, E. Radiação: efeitos, riscos e benefícios. São Paulo: Harbra, 1998.

ORGANIZACIÓN MUNDIAL DE LA SALUD (OMS). Critérios de salud ambiental. Micotoxinas, México: OMS, 1983. v. 11, 131 p.

ORGANIZACIÓN MUNDIAL DE LA SALUD (OMS). La irradiación de los alimentos una técnica para conservar y preservar la inocuidad de los alimentos. Genebra: Organización Mundial de la Salud, 1989. p. 18-23.

ONYENEKWE, P. C.; OGBADU, G. H.; HASHIMOTO, S. The effect of gamma radiation on the microflora and essential oil of Ashanti pepper (Piper guineense) berries Postharvest, Biol. Technol., v. 10, p. 161-167, 1997. 
PACHECO, A. M.; LUCAS, A.; PARENTE, R.; PACHECO, N. Association between aflatoxin and aflatoxigenic fungi in Brazil nuts (Bertholletia excelsa H.B.K.). Ciência Tecnol. Alimentos, v. 30, p. 330-334, 2010.

PACHECO, A. M; SCUSSEL, V. M. Selenium and aflatoxins levels in raw Brazil nuts from the Amazon basin. Journal of Agricultural and Food Chemistry, v. 55, p. 11087-11092, 2007.

PELCZAR JR, M. J.; CHAN, E. C. S.; KRIEG, N. R. Controle de Microrganismos: Fundamentos e Agentes Físicos. In: Microbiologia: Conceitos e Aplicações. 2. ed. São Paulo: Makron Books, 1996. vol. 1, cap. 7, p. 198-200.

PENNACCHIO, H. L. Castanha-do-Brasil proposta de preço mínimo safra 2006/2007. Revista Conab, v. 1, p. 124-127, 2007.

PENNACCHIO, H. L. Conjuntura mensal castanha-do-Brasil. Brasília: Conab/Mapa, 2012. 3 p.

PEREIRA, M. M. G. et al. Aflatoxinas em alimentos destinados a bovinos e em amostras de leite da região de Lavras, Minas Gerais - Brasil. Ciênc. Agrotec. [online], v. 29, n. 1, p. 106$112,2005$.

PILDAIN, M. B.; VAAMONDE, G.; CABRAL, D. Analysis of population structure of Aspergillus flavus from peanut based on vegetative compatibility, geographic origin, mycotoxin and sclerotia production. Int. J. Food Microbiology, v. 93, p. 31-40, 2004.

PITT, J, L. An introduction to mycotoxins. Agriculture and Consumer protection/FAO. Disponível em: <http://www.fao.org/docrep/x5036e/x5036E04.htm>. Acesso em: 01 Sep 2012.

PITT, J. I.; HOCKING, A. D. Fungi and food spoilage. London: Blackie Academic Professional, 2009. p. 519.

PITT, J. I.; HOCKING, A. D. Fungi and food spoilage. 2nd ed. London: Beackie Academic and Professional, 1997. 593 p.

POLLARD, E. C. Phenomenology of radiation effects on microrganisms. In:

Encyclopedia of Medical Radiology. New York: Springer-Verlag, 1966. vol. 2, p. 1-34.

POZZI, C. R. et al. Postharvest and stored corn in Brazil: mycoflora interaction, abiotic factors and mycotoxin occurrence. Food Add. Contam., v. 12, n. 3, p. 313-319, 1995. Suppl.

PRADO, G. et al. Effect of gamma irradiation on the inactivation of aflatoxin $\mathrm{B}_{1}$ and fungal flora in peanut. Braz. J. Microbiol., v. 34, p. 138-140, 2003. Suppl. 1.

RAMAKRISHNA, N.; LACEY, J.; SMITH, J. E. Effect of surface sterization, fumigation and gamma irradiation on the microflora and germination of barley seeds. Int. J. Food Microbiol., v. 13, p. 47-54, 1991. 
REIS, T. A.; OLIVEIRA, T. D.; BAQUIAO, A. C.; GONÇALEVS, S. S.; ZORZETE, P. CORREA, B. Mycobiota and mycotoxins in Brazil nut samples from different states of the Brazilian Amazon region. International Journal of Food Microbiology, v. 159, p. 61-68, 2012.

ROGOVSCHI, V. D.; AQUINO, S.; NUNES, T. C. F.; GONÇALEZ, E.; CORREA, B.; VILLAVICENCIO, A. L. C. H. Use of electron beam on aflatoxins degradation in coconut agar. International Nucelar Atlantic Conference, Rio de Janeiro, 2009. p. 4.

RUSTOM, I. Y. S. Aflatoxin in food and feed: occurrence, legislation and inactivation by physical methods. Food Chem., v. 59. n. 1, p. 57-67, 1997. Suppl.

SABATO, S. Introdução à irradiação de alimentos. São Paulo: IPEN, 2005. Material didático do curso de Mestrado no CTR do Instituto de Pesquisas Energéticas Nucleares da Universidade de São Paulo.

SABINO, M. programa nacional de monitoração de micotoxinas. In: SCUSSEL, V. M. (Ed.) Atualidades em micotoxinas e armazenagem de grãos. Florianópolis, 2000. p. 93-96.

SABINO, M. Retrospectiva e situação atual das micotoxinas. In: ENCONTRO NACIONAL DE MICOTOXINAS, 11., 2004, Piracicaba. Resumos.... Piracicaba: Laboratório de Micotoxinas - LAN/ESALQ-USP, 2004. p. 10-12.

SAITO, M.; ENOMOTO, M.; TATSUNO, T.; URAGUCHI, K. Yellowed rice toxins. In: CIEGLER, A.; KADIS, S.; AHL, S. J. (Ed.). Microbial toxins, a comprehensive treatise: fungal toxins. London: Academic Press, 1971. v. 6, p. 299-380.

SALEH, Y. G.; MAYO, M. S.; AHEARN, D. G. Notes: resistance of some commom fungi to gamma irradiation. Appl. Environ. Microbiol., v. 54, n. 8, p. 2134-2135, 1988.

SAMSOM, R. A.; VARGA, J. "What is a species in Aspergillus?". Med. Mycol., v. 47, p. 1320, 2009.

SANTURIO, J. M. Micotoxinas e micotoxicoses na avicultura. Rev. Bras. Ciênc., v. 2, n. 1, p. 1-12, 2000.

SATIN, M. The case of food irradiation. International Conference of the Agricultural Research Institute, p. 93-110, 1993.

SATO, S. General View of electron acellerator utilization. In: Proceedings of the workshops on the utilization of electron beams. JAERI- M/93-160, Bangkok e Jakarta, 1993.

SCOTT, P. M. Natural poisons. In: HELRICH, K. Association of the official analytical chemists. 15. ed. Arlington: Official Methods of Analysis, 1990. Cap. 49, p. 1184-1213.

SCUSSEL, V. M.; GIORDANO, B. N.; SIMÃO, V.; MANFIO, D.; GALVAO, S.; NAZAR, M. N. F. Effect of oxygen-reducing atmospheres on the safety of packaged shelled Brazil nuts during storage. Int. J. Anal. Chem., v. 2011, p. 1-9, 2011. 
SEKIYAMA, B. L.; FERRARI, G.; JUNIOR, M. M. Processos de descontaminação de rações contendo micotoxinas. Rev. Analytica, n. 26, p. 64-67, 2007.

SHAHBAZI, H. R.; SHWRANG, P.; SADEGHJ, A. A. Effects of gamma and electron-beam irradiation on aflatoxin $B_{1}$ content of corn grain. Animal Sciences Journal, v. 3, p. 56-61, 2010.

SILVA, A. C. O. Efeito da radiação gama sobre lipídios, microbiota contaminante e validade comercial do leite cru integral refrigerado e sobre caractarísticas sensoriais do leite pasteurizado integral refrigerado. 2008. 90 f. Dissertação (Mestrado em Higiene Veterinária e Processamento Tecnológico de Produtos de Origem Animal) - Niterói, Rio de Janeiro, 2008.

SILVA, L. G. A.; DIAS, D. B.; MIRANDA, F.; CALVO, W. A. P. Processamento por feixe de elétrons em polímeros. In: CONGRESSO BRASILEIRO DE POLÍMEROS, 11., 2011, São Paulo. Anais... São Paulo: IPEN-CNEN/SP, 2011.

SILVA, R. F.; ASCHERI, J. L. R.; SOUZA, J. M. L. Influência do processo de beneficiamento na qualidade de amêndoas de castanha-do-Brasil. Ciênc. Agrotec., v. 34, n. 2, p. 445-450, 2010.

SMITH, J. E.; ROSS, I. C. The toxigenic Aspergillus. In: SMITH, J. E.; HENDERSON, R. S. (Ed.). Mycotoxins and animal foods. London: CRC Press, 1991. p. 31-61.

SMITH, D, et al. Physiology of Aspergillus in: SMITH, J. E. (Ed.) Aspergillus. Plenum Press, New York, p. 23-37, 1994.

SOUZA, M. L. Estudo de processos tecnológicos para a obtenção de produtos derivados da castanha-do-Brasil (Bertholletia excelsa, H.B.k.). 1984. 139 f. Dissertação (Mestrado em Tecnologia de Alimentos) - Universidade Federal do Ceará, Ceará, 1984.

SOUZA, M. L.; MENEZES, H. C. Processamentos de amêndoa e torta de castanha-do-Brasil e farinha de mandioca: parâmetros de qualidade. 2004. Ciência e Tecnologia de Alimentos, p. 120-128, 2004.

SPINKS, J. W. T.; WOODS, R. J. An introduction to radiation chemistry. 3rd ed. New York, USA: Wiley-Interscience Publication, 1990.

SPOLAORE, A. J. G.; GERMANO, M. I. S.; GERMANO, P. M. L. Irradiação de alimentos. In: GERMANO, P. M. L.; GERMANO, M. I. S. Higiene e vigilância sanitária de alimentos: qualidade das matérias primas, doenças transmitidas por alimentos, treinamento de recursos humanos. 2. ed. São Paulo: Varela, 2003.

STEINER, W. E.; BRUNSCHWEILER, K.; LEIMBACHER, E.; SCHENEIDER, R. Aflatoxins and fluorescence in Brazil nuts and pistachio nuts. Journal of Agricultural and Food Chemistry, v. 40, p. 2453-2457, 1992.

STEYN, P. S. Mycotoxins, excluding aflatoxins, zearalelone and the trichothecenes. In: RODRICKS, J. V. et al. Mycotoxins in human and animal health. Illinois: Pathotox Publishers, 1977. p. 419-467. 
STOIAN, D. Consechando lo que cae: la economia de la castana (Bertholletia excelsa H.B.K) em la Amazonia Boliviana. In: ALEXIADES, M. N.; SHANLEY, P. Productos forestales, medios de subsistencia y conservación de productos florestales no maderables. Cifor, Indonésia, v. 3, cap. 5, p. 89-116, 2004.

STOLOFF, L. The three eras of fungal toxin research. J. Am. Oil Chem. Soc., v. 56, n. 9, p. 784-788, 1979.

TANIWAKI, M. H.; SILVA, N. Fungos em alimentos: ocorrência e detecção. Campinas: Núcleo de Microbiologia/ITAL, 2001. 82 p.

TEMCHAROEN, P.; THILLY, W. Removal of aflatoxin $\mathrm{B}_{1}$ toxicity but not mutagenicity by 1 megarad gamma radiation of peanut meal. J. Food Safety, v. 4, p. 199-205, 1982.

TONINI, H.; COSTA, P.; KAMINSKI, P. E. Manejo de produtos florestais não madeireiros na Amazonia - (Castanheira-do-Brasil) resultados de pesquisa. Boletim de Pesquisa e desenvolvimento, EMBRAPA, v. 2, 39 p., 2008.

TSAI, D. Aplicação da radiação por feixe de elétrons como agente esterilizante de microrganismos em substrato turfoso. 2006. 119 f. Dissertação (Mestrado em Tecnologia Nuclear) - Instituto de Pesquisas Energéticas e Nucleares, Universidade de São Paulo, São Paulo, 2006.

VAN DER ZIJDEN, A. S. M. et al. Isolation in crystalline form of a toxin responsible for turkey X disease. Nature, London, v. 195, p. 1062, 1962.

VARGAS, E. A.; SANTOS, E. A.; WHITAKER, T. B.; SLATE, A. B. Determination of aflatoxin risk components for in-shell Brazil nuts. Food Addit. Contamin., v. 28, p. 12421260, 2011.

VILLAVICENCIO, A. L. C. H. Avaliação dos efeitos da radiação ionizante de 60 Co em propriedades físicas, químicas e nutricionais dos feijões Phaseolus vulgaris L. e Vigna unguiculata (L) Walp. 1998. Tese (Doutorado) - Faculdade de Ciências Farmacêuticas da Universidade de São Paulo, São Paulo, 1998.

VISCONTI, A. et al. Stability of fumonisins at different storage periods and temperatures in g-irradiated maiz. Food Add. Contam., v. 13, p. 929-938, 1996.

WORLD HEALTH ORGANIZATION (WHO). Mycotoxins. Enviromental Health Criteria, Geneva, n. 11, p. 21-84, 1979.

WORLD HEALTH ORGANIZATION (WHO). Safaty and Nutritional Adequacy of Irradiated Food, Geneva, p. 1-77, 1994.

WIENDL, F. M. Irradiação de alimentos. Biológico, v. 59, n. 1, p. 75-76, 1997

WIKIMEDIA. Alpha, beta, gamma radiation penetration. Disponível em: < http://upload.wikimedia.org/wikipedia/commons/6/61/Alfa_beta_gamma_radiation_penetrati on.svg> Acesso em: 22 aug/2012. 
WINSTON, P. W.; BATES. D. H. Satured salt solutions for the control of humidity in biological research. Rev. Ecology, v. 41, p. 232-237, 1960.

WYLLIE, T. D.; MOREHOUSE, L. G. Mycotoxic fungi, mycotoxins and mycotoxicoses: mycotoxic fungi and chemistry of mycotoxins. New York: Marcel Dekker, 1977. vol. 1, p. 537.

XAVIER, J. G. et al. Equine leukoencephalomalacia: Report of five cases. Brazil. J. Vet. Res. Animal Sci., v. 28, p. 185-189, 1991.

ZAIN, M. E. Impact of mycotoxins on humans and animals. Journal of Saudi Chemical Society, v. 15, n. 2, p. 129-144, 2011. 


\section{ANEXO A - Figuras}

Figura 1.A - Castanheira

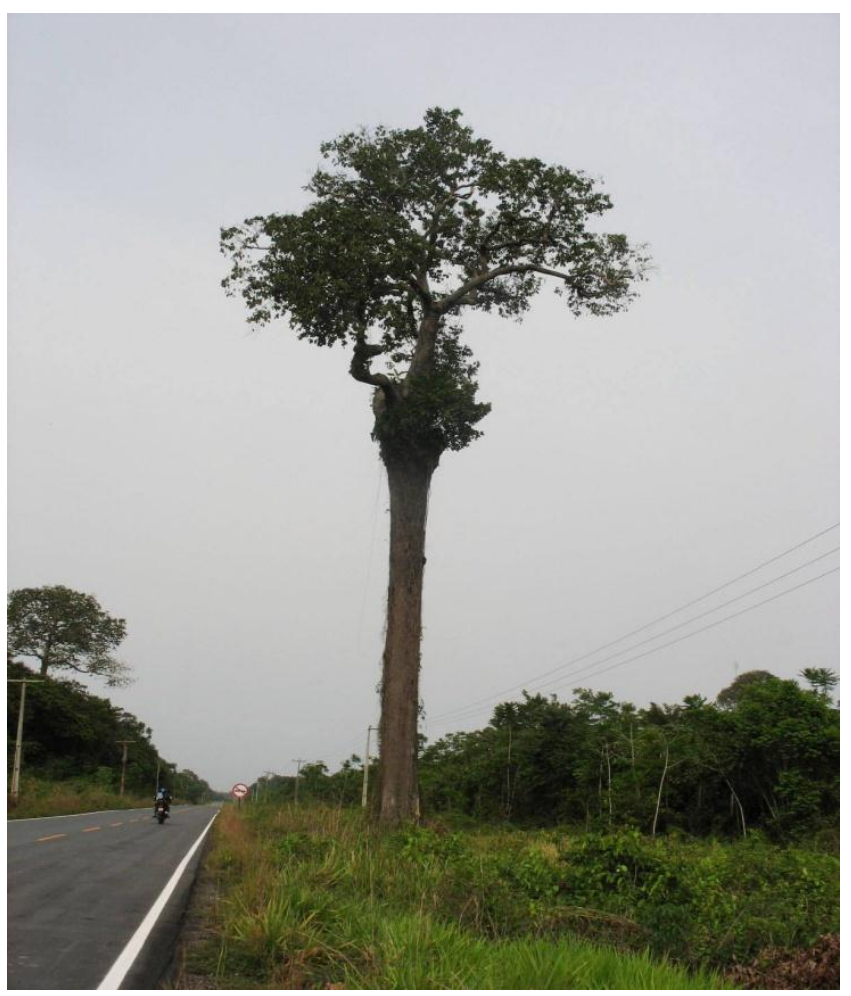

Fonte: (BAQUIÃO, 2012)

Figura 2.A - Castanha-do-Brasil com casca dentro do ouriço

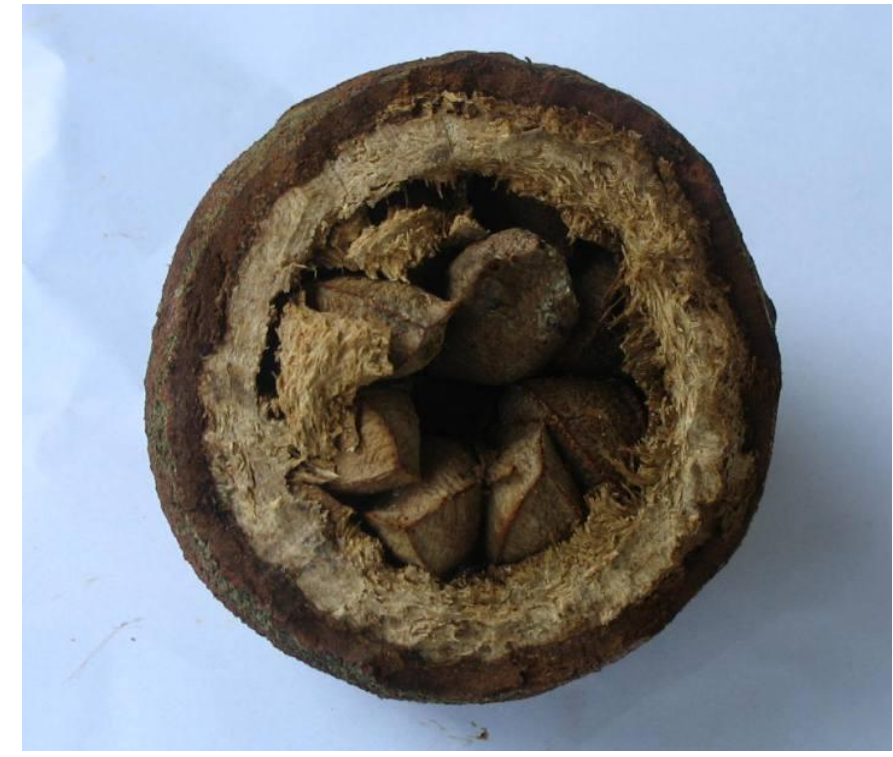

Fonte: (BAQUIÃO, 2012). 
Figura 3.A - Radura

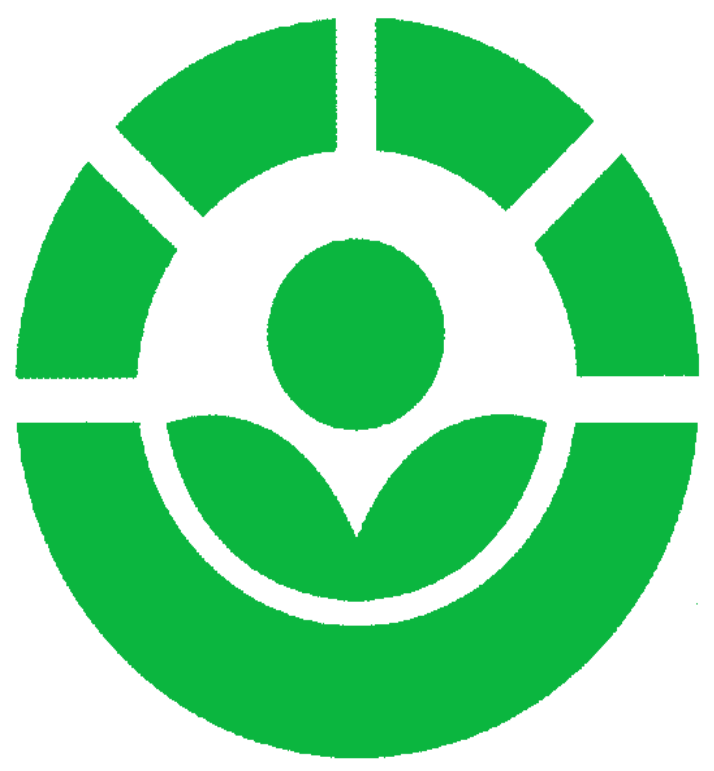




\section{APÊNDICE A - Figuras}

Figura 1.AP - Fonte Gammacell ${ }^{60} \mathrm{Co}$

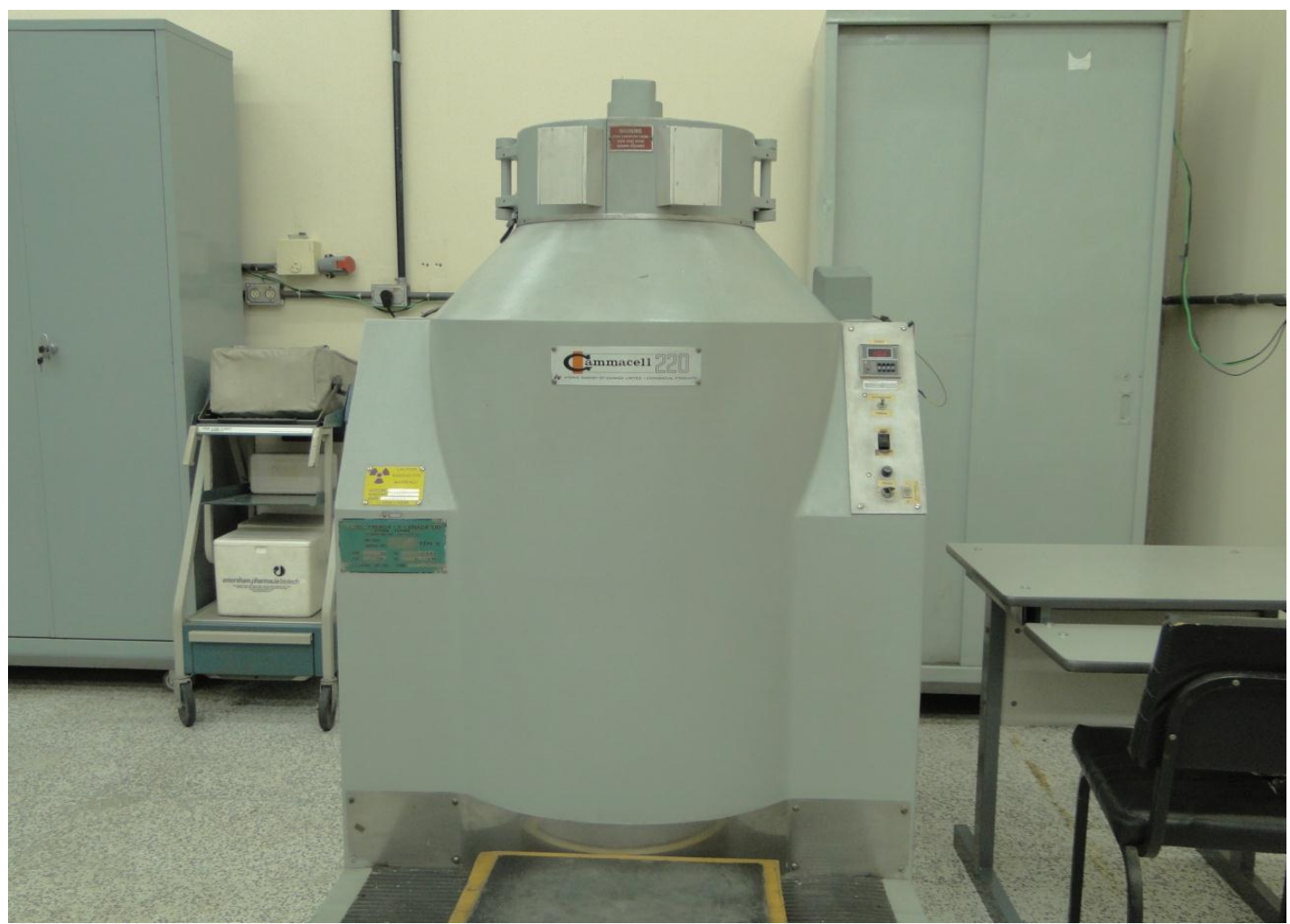

Figura 2.AP - Acelerador de Elétrons

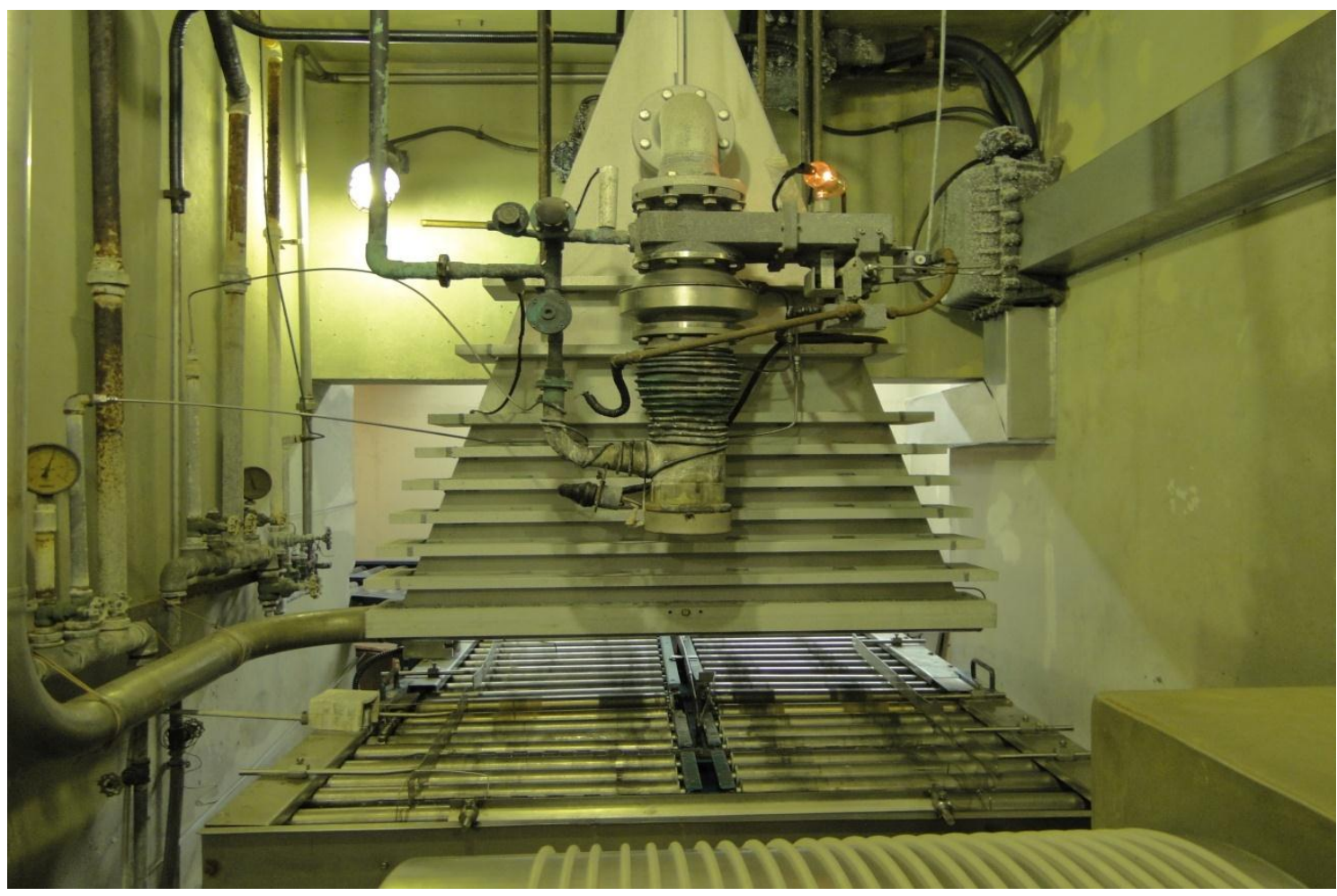


Figura 3.AP - Aparelho de atividade de água Aqualab Cx - 2

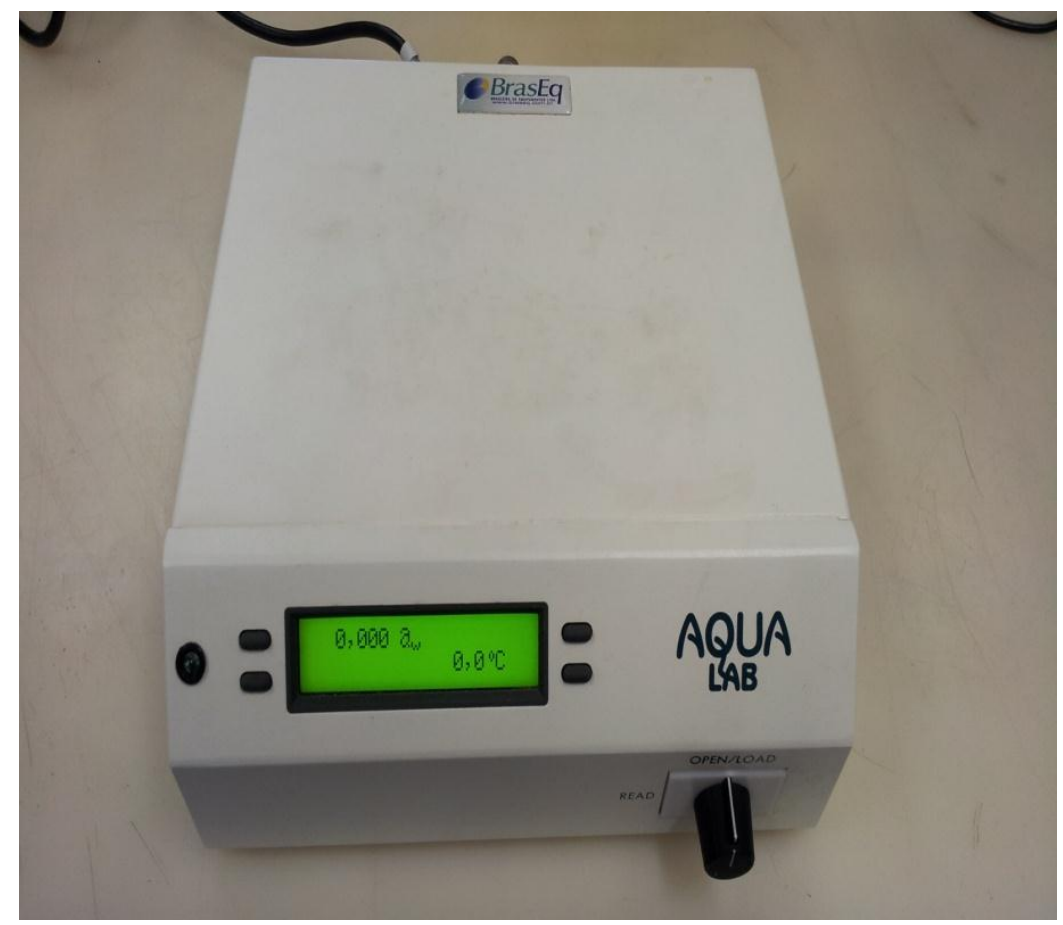

Figura 4.AP - Cromatógrafo líquido de alta eficiência

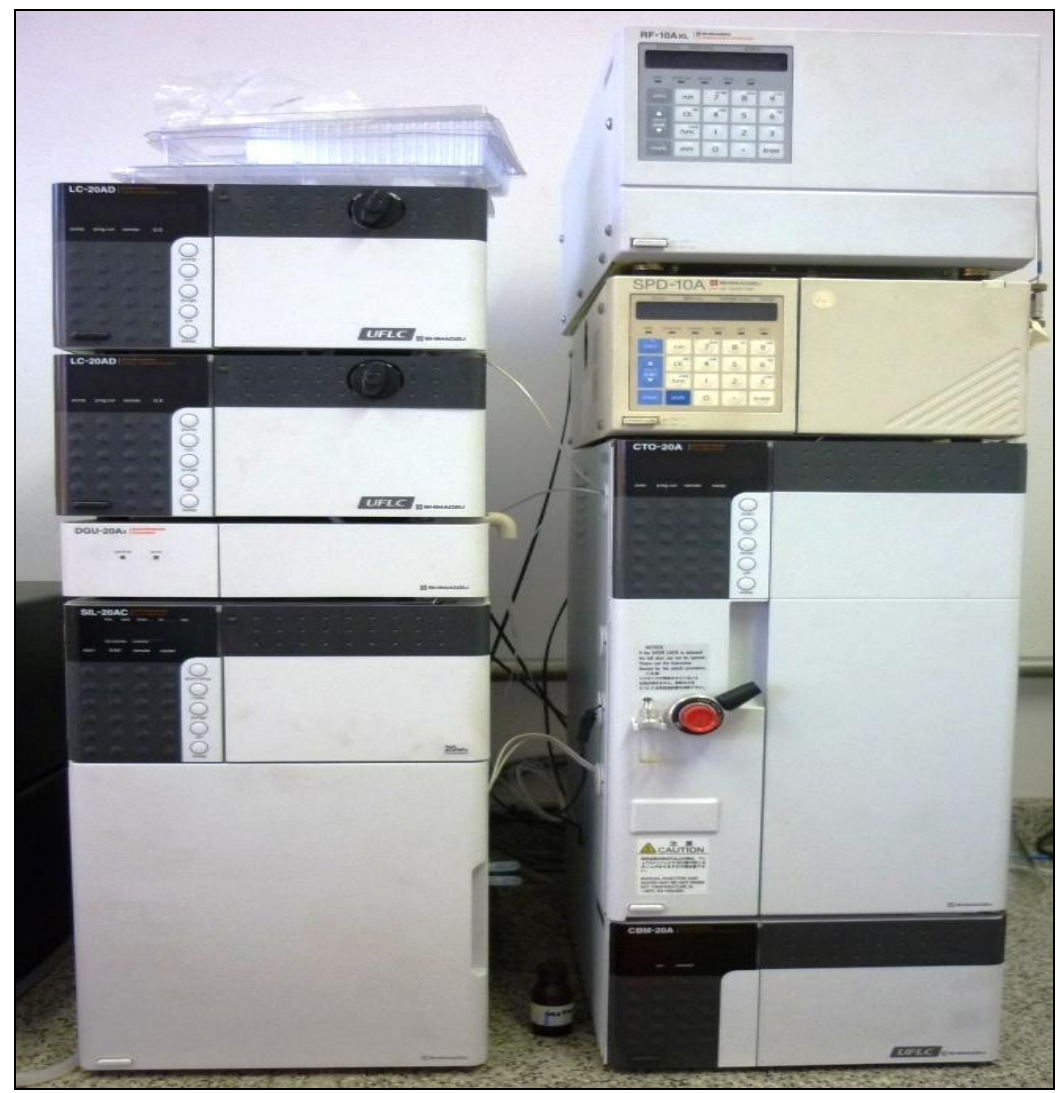


Figura 5.AP - Amostra embalada

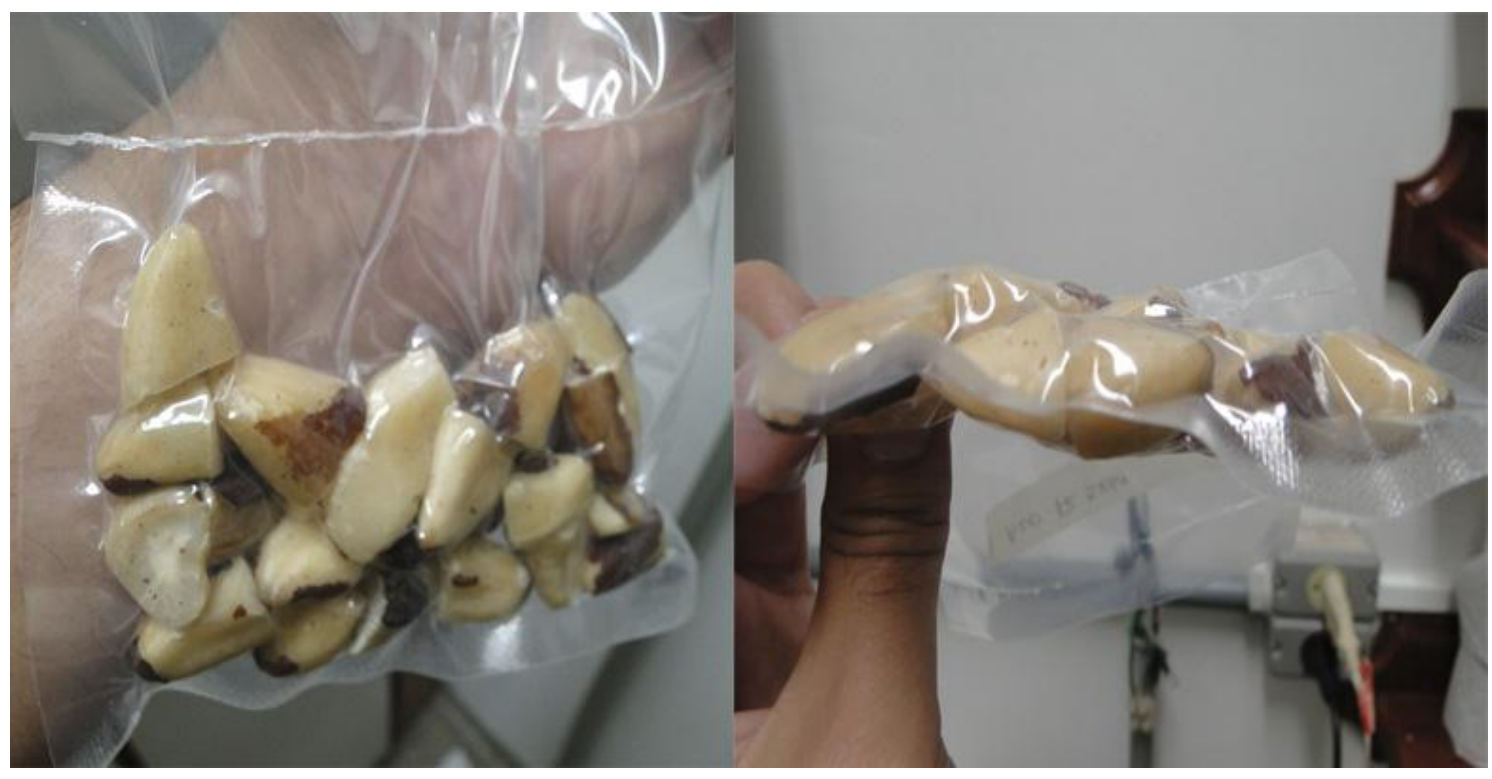

Figura 6.AP - Micobiota antes dos processos de radiação

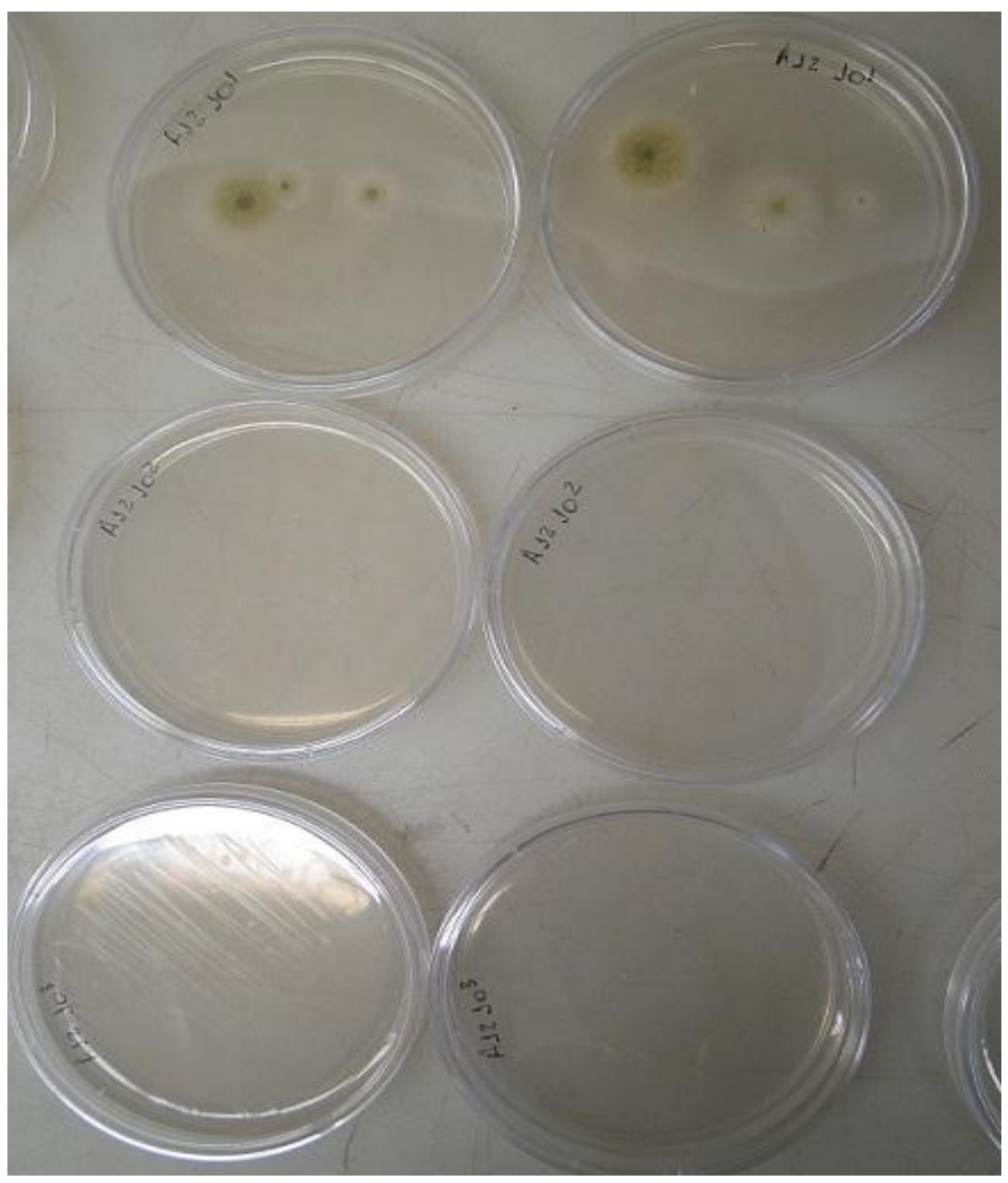


Figura 7.AP - Micobiota após o processo de irradiação com 5 kGy por Feixe de Elétrons

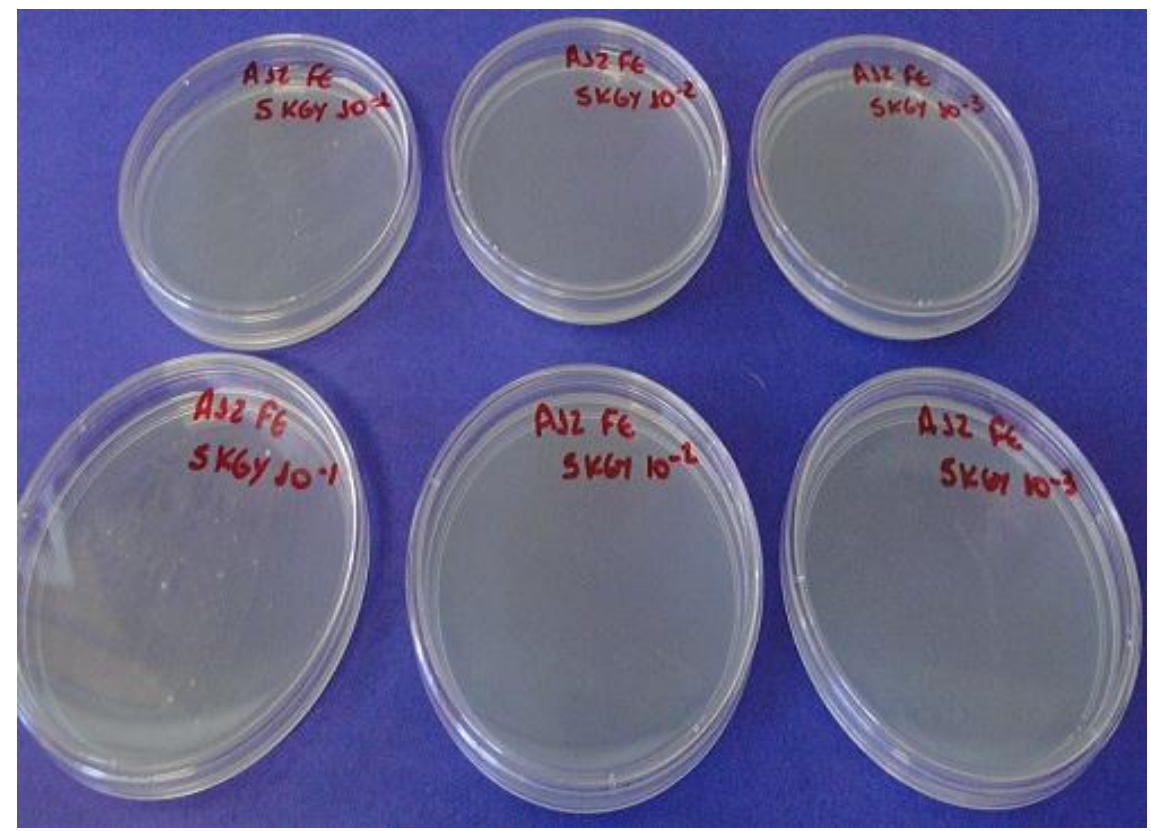

Figura 8.AP - Micobiota após o processo de irradiação com 10 kGy por Feixe de Elétrons

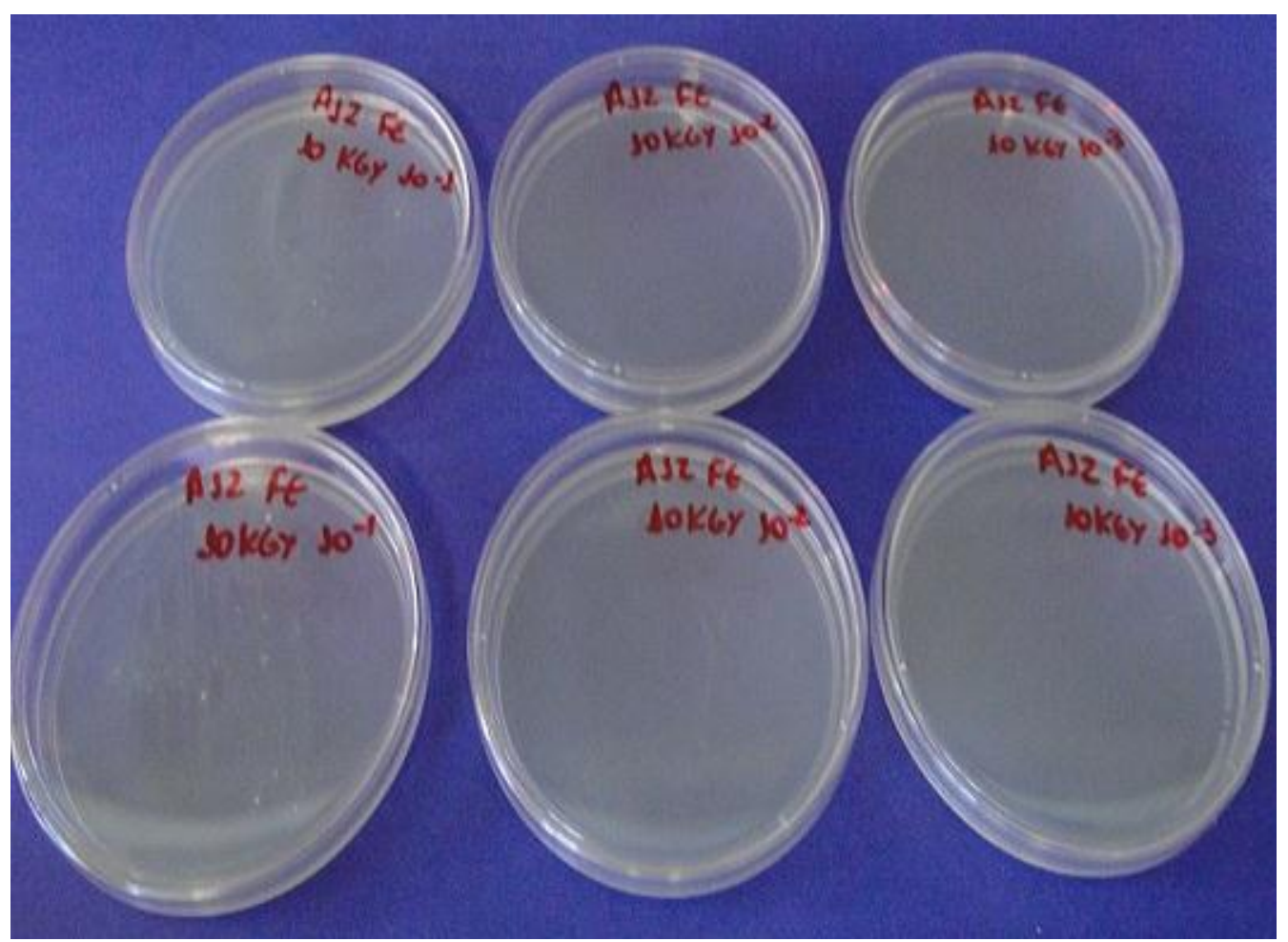


Figura 9.AP - Micobiota após o processo de irradiação com 5 kGy por Radiação Gama.

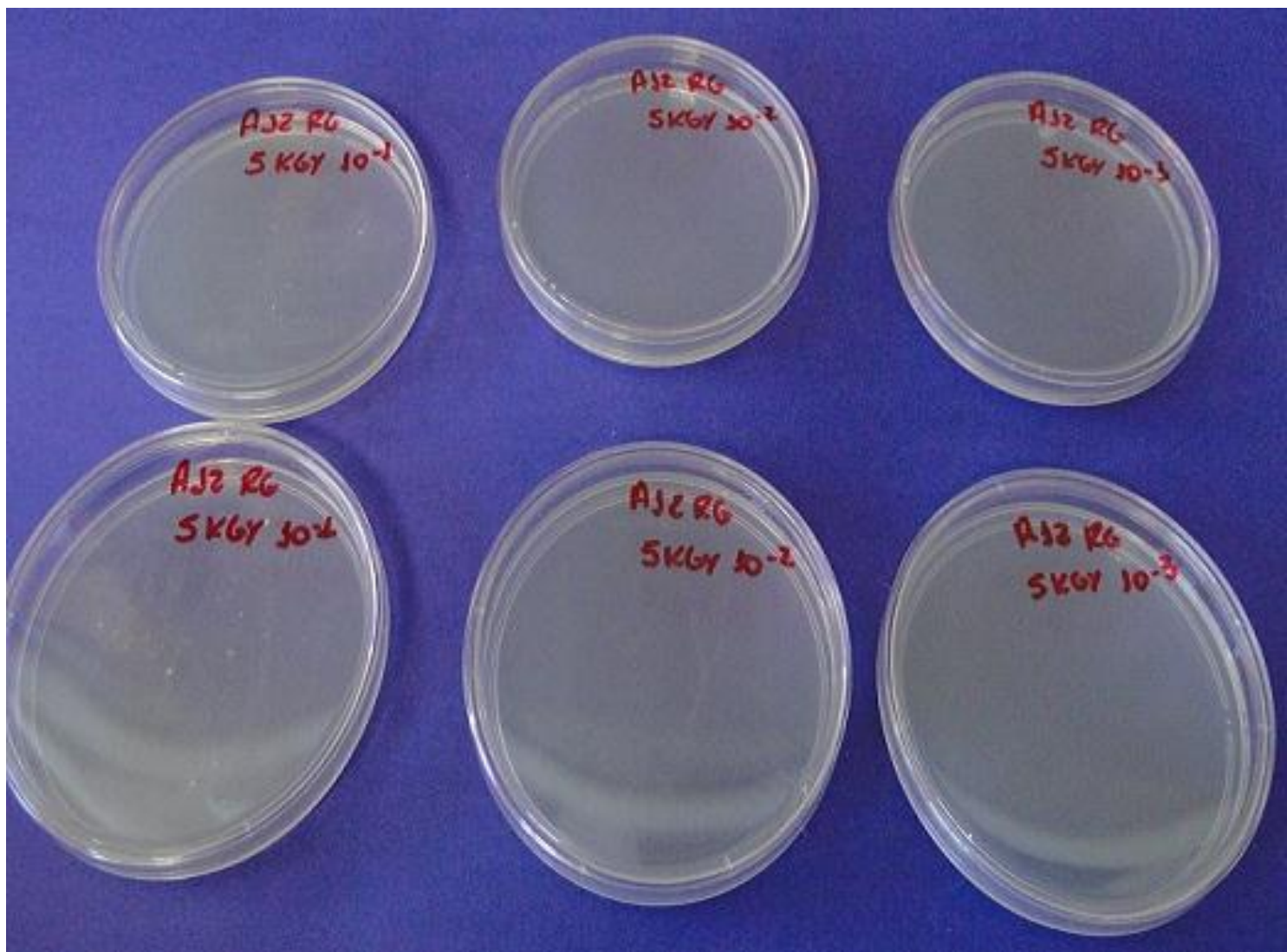

Figura 10.AP - Micobiota após o processo de irradiação com 10 kGy por Radiação Gama.

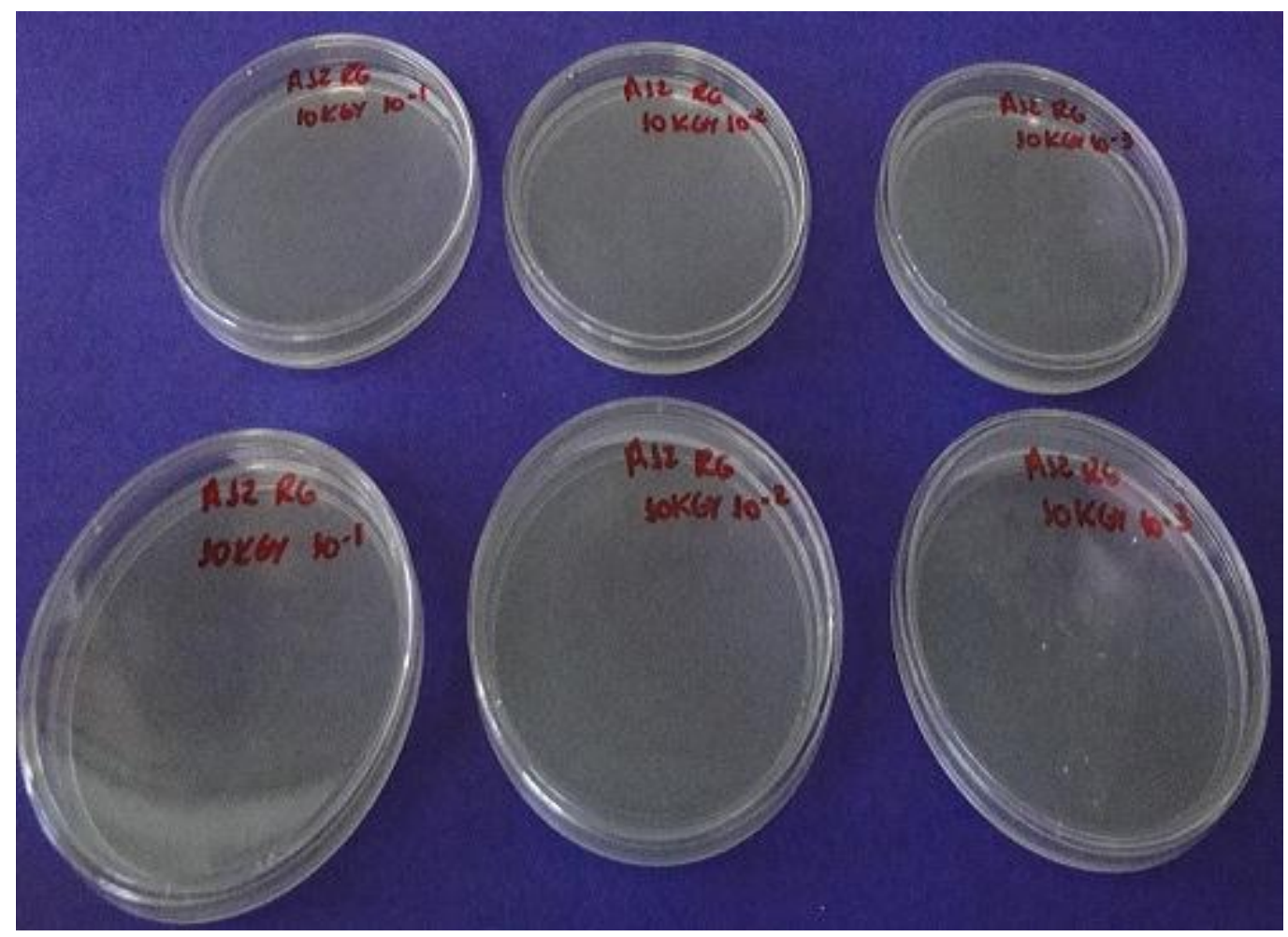




\section{APÊNDICE B - Quadros}

Notas atribuídas pelos provadores na análise sensorial de castanha-do-Brasil

Quadro 1.B - Odor

\begin{tabular}{|c|c|c|c|c|c|}
\hline Provadores & Controle & 5 kGy F.E & 5 kGy R.G & 10 kGy F.E & 10 kGy R.G \\
\hline Provador 1 & 8 & 5 & 5 & 5 & 5 \\
\hline Provador 2 & 8 & 6 & 6 & 7 & 7 \\
\hline Provador 3 & 8 & 8 & 7 & 8 & 8 \\
\hline Provador 4 & 2 & 7 & 3 & 6 & 3 \\
\hline Provador 5 & 8 & 8 & 8 & 7 & 8 \\
\hline Provador 6 & 7 & 4 & 4 & 5 & 5 \\
\hline Provador 7 & 8 & 8 & 7 & 8 & 7 \\
\hline Provador 8 & 7 & 3 & 3 & 5 & 3 \\
\hline Provador 9 & 7 & 7 & 7 & 7 & 7 \\
\hline Provador 10 & 8 & 7 & 8 & 8 & 8 \\
\hline Provador 11 & 8 & 9 & 7 & 8 & 9 \\
\hline Provador 12 & 8 & 3 & 4 & 5 & 5 \\
\hline Provador 13 & 7 & 2 & 5 & 7 & 5 \\
\hline Provador 14 & 8 & 7 & 7 & 7 & 7 \\
\hline Provador 15 & 7 & 3 & 3 & 3 & 3 \\
\hline Provador 16 & 8 & 3 & 5 & 7 & 1 \\
\hline Provador 17 & 9 & 6 & 6 & 6 & 6 \\
\hline Provador 18 & 6 & 5 & 5 & 5 & 5 \\
\hline Provador 19 & 8 & 4 & 4 & 6 & 5 \\
\hline Provador 20 & 8 & 4 & 5 & 7 & 7 \\
\hline Provador 21 & 8 & 8 & 9 & 7 & 8 \\
\hline Provador 22 & 7 & 6 & 5 & 5 & 6 \\
\hline Provador 23 & 7 & 6 & 9 & 6 & 7 \\
\hline Provador 24 & 8 & 5 & 7 & 5 & 5 \\
\hline Provador 25 & 8 & 5 & 5 & 2 & 5 \\
\hline Provador 26 & 8 & 7 & 5 & 6 & 5 \\
\hline
\end{tabular}




\begin{tabular}{|l|l|l|l|l|l|}
\hline Provador 27 & 8 & 3 & 4 & 5 & 5 \\
\hline Provador 28 & 9 & 7 & 5 & 9 & 9 \\
\hline Provador 29 & 8 & 5 & 5 & 4 & 6 \\
\hline Provador 30 & 8 & 4 & 5 & 3 & 5 \\
\hline
\end{tabular}

Quadro 2.B - Sabor

\begin{tabular}{|c|c|c|c|c|c|}
\hline Provadores & Controle & 5 kGy F.E & 5 kGy R.G & 10 kGy F.E & 10 kGy R.G \\
\hline Provador 1 & 8 & 3 & 3 & 4 & 4 \\
\hline Provador 2 & 8 & 4 & 4 & 7 & 8 \\
\hline Provador 3 & 8 & 7 & 7 & 8 & 8 \\
\hline Provador 4 & 2 & 6 & 3 & 6 & 3 \\
\hline Provador 5 & 7 & 8 & 8 & 7 & 8 \\
\hline Provador 6 & 6 & 1 & 2 & 3 & 4 \\
\hline Provador 7 & 8 & 3 & 3 & 7 & 6 \\
\hline Provador 8 & 7 & 3 & 3 & 4 & 1 \\
\hline Provador 9 & 8 & 7 & 4 & 7 & 4 \\
\hline Provador 10 & 8 & 7 & 7 & 8 & 7 \\
\hline Provador 11 & 1 & 2 & 2 & 2 & 2 \\
\hline Provador 12 & 6 & 3 & 6 & 2 & 8 \\
\hline Provador 13 & 6 & 2 & 6 & 8 & 6 \\
\hline Provador 14 & 7 & 6 & 6 & 7 & 8 \\
\hline Provador 15 & 8 & 2 & 1 & 2 & 2 \\
\hline Provador 16 & 8 & 3 & 2 & 8 & 1 \\
\hline Provador 17 & 9 & 4 & 7 & 9 & 4 \\
\hline Provador 18 & 6 & 3 & 2 & 6 & 4 \\
\hline Provador 19 & 8 & 3 & 2 & 6 & 2 \\
\hline Provador 20 & 8 & 4 & 4 & 7 & 5 \\
\hline Provador 21 & 8 & 2 & 2 & 3 & 3 \\
\hline Provador 22 & 6 & 4 & 3 & 6 & 7 \\
\hline Provador 23 & 8 & 9 & 9 & 7 & 8 \\
\hline Provador 24 & 9 & 5 & 5 & 5 & 5 \\
\hline
\end{tabular}




\begin{tabular}{|l|c|c|c|c|c|}
\hline Provador 25 & 8 & 2 & 2 & 2 & 4 \\
\hline Provador 26 & 7 & 4 & 2 & 8 & 3 \\
\hline Provador 27 & 8 & 2 & 6 & 8 & 7 \\
\hline Provador 28 & 9 & 1 & 2 & 7 & 8 \\
\hline Provador 29 & 8 & 3 & 2 & 4 & 1 \\
\hline Provador 30 & 8 & 3 & 3 & 7 & 4 \\
\hline
\end{tabular}

Quadro 3.B - Textura

\begin{tabular}{|l|c|c|c|c|c|}
\hline Provadores & Controle & 5 kGy F.E & 5 kGy R.G & 10 kGy F.E & 10 kGy R.G \\
\hline Provador 1 & 8 & 6 & 5 & 4 & 4 \\
\hline Provador 2 & 6 & 6 & 4 & 7 & 6 \\
\hline Provador 3 & 9 & 7 & 7 & 8 & 8 \\
\hline Provador 4 & 2 & 6 & 3 & 6 & 3 \\
\hline Provador 5 & 7 & 8 & 8 & 7 & 8 \\
\hline Provador 6 & 6 & 1 & 2 & 3 & 4 \\
\hline Provador 7 & 8 & 6 & 7 & 8 & 6 \\
\hline Provador 8 & 8 & 3 & 3 & 4 & 2 \\
\hline Provador 9 & 8 & 8 & 7 & 8 & 8 \\
\hline Provador 10 & 7 & 7 & 5 & 8 & 5 \\
\hline Provador 11 & 9 & 2 & 2 & 7 & 9 \\
\hline Provador 12 & 9 & 6 & 7 & 4 & 9 \\
\hline Provador 13 & 4 & 1 & 6 & 6 & 6 \\
\hline Provador 14 & 7 & 7 & 7 & 6 & 6 \\
\hline Provador 15 & 8 & 2 & 5 & 5 & 8 \\
\hline Provador 16 & 9 & 8 & 7 & 9 & 4 \\
\hline Provador 17 & 9 & 8 & 8 & 9 & 8 \\
\hline Provador 18 & 7 & 7 & 6 & 8 & 5 \\
\hline Provador 19 & 8 & 5 & 5 & 6 & 5 \\
\hline Provador 20 & 8 & 5 & 5 & 5 & 8 \\
\hline Provador 21 & 9 & 8 & 7 & 3 & 5 \\
\hline Provador 22 & 7 & 3 & 6 & 5 & 5 \\
\hline
\end{tabular}




\begin{tabular}{|l|l|l|l|l|l|}
\hline Provador 23 & 8 & 8 & 7 & 6 & 8 \\
\hline Provador 24 & 8 & 5 & 5 & 8 & 7 \\
\hline Provador 25 & 8 & 2 & 4 & 2 & 4 \\
\hline Provador 26 & 7 & 7 & 4 & 8 & 5 \\
\hline Provador 27 & 8 & 7 & 7 & 7 & 7 \\
\hline Provador 28 & 9 & 9 & 9 & 3 & 9 \\
\hline Provador 29 & 8 & 7 & 8 & 8 & 5 \\
\hline Provador 30 & 8 & 5 & 6 & 7 & 4 \\
\hline
\end{tabular}




\section{APÊNDICE C - Modelo de ficha de análise sensorial}

Nome Idade

Por favor, avalie a amostra utilizando a escala abaixo para dizer o quanto você gostou ou desgostou do produto. Marque com um $\mathbf{X}$ a posição que melhor reflete a sua opinião.

Código da amostra:

\begin{tabular}{|c|c|c|}
\hline \multicolumn{2}{|c|}{ ODOR } \\
\hline & 9 & Gostei extremamente \\
\hline & 8 & Gostei muito \\
\hline & 7 & Gostei moderadamente \\
\hline & 6 & Gostei ligeiramente \\
\hline & 5 & Indiferente \\
\hline & 4 & Desgostei ligeiramente \\
\hline & 3 & Desgostei moderadamente \\
\hline & 2 & Desgostei muito \\
\hline
\end{tabular}

Código da amostra:

\begin{tabular}{|c|c|c|}
\hline \multicolumn{2}{|c|}{ SABOR } \\
\hline & 9 & Gostei extremamente \\
\hline & 8 & Gostei muito \\
\hline & 7 & Gostei moderadamente \\
\hline & 6 & Gostei ligeiramente \\
\hline & 5 & Indiferente \\
\hline & 4 & Desgostei ligeiramente \\
\hline & 3 & Desgostei moderadamente \\
\hline & 2 & Desgostei muito \\
\hline
\end{tabular}

Código da amostra:

\begin{tabular}{|c|c|c|}
\hline \multicolumn{3}{|c|}{ TEXTURA } \\
\hline & 9 & Gostei extremamente \\
\hline & $\mathbf{8}$ & Gostei muito \\
\hline & 7 & Gostei moderadamente \\
\hline & $\mathbf{6}$ & Gostei ligeiramente \\
\hline & 5 & Indiferente \\
\hline & $\mathbf{5}$ & Desgostei ligeiramente \\
\hline & 3 & Desgostei moderadamente \\
\hline & 2 & Desgostei muito \\
\hline & $\mathbf{1}$ & Desgostei extremamente \\
\hline
\end{tabular}

Comentários: 